University of San Diego

Digital USD

2016

\title{
The Effect of Organizational Commitment, Organizational Based Self Esteem and Work Engagement on Nurses' Perception of Medication Errors
}

Vanessa V. Wertheim

University of San Diego

Follow this and additional works at: https://digital.sandiego.edu/dissertations

Part of the Nursing Commons

\section{Digital USD Citation}

Wertheim, Vanessa V., "The Effect of Organizational Commitment, Organizational Based Self Esteem and Work Engagement on Nurses' Perception of Medication Errors" (2016). Dissertations. 61.

https://digital.sandiego.edu/dissertations/61

This Dissertation: Open Access is brought to you for free and open access by the Theses and Dissertations at Digital USD. It has been accepted for inclusion in Dissertations by an authorized administrator of Digital USD. For more information, please contact digital@sandiego.edu. 


\section{UNIVERSITY OF SAN DIEGO \\ Hahn School of Nursing and Health Science \\ DOCTOR OF PHILOSOPHY IN NURSING}

The Effect of Organizational Commitment, Organizational Based

Self Esteem and Work Engagement on Nurses' Perception of Medication Errors

$$
\text { by }
$$

Vanessa V. Wertheim

A dissertation presented to the

FACULTY OF THE HAHN SCHOOL OF NURSING AND HEALTH SCIENCE

UNIVERSITY OF SAN DIEGO

In partial fulfillment of the

Requirements for the degree

DOCTOR OF PHILOSOPHY IN NURSING

February 8, 2016

Dissertation Committee

Linda Urden, DNSc, RN, CNS, NE-BC, FAAN, Chairperson Ann Mayo, DNSc, RN, FAAN Jane Georges, $\mathrm{PhD}$, RN 


\section{UNIVERSITY OF SAN DIEGO}

Hahn School of Nursing and Health Science

DOCTOR OF PHILOSOPHY IN NURSING

CANDIDATE'S NAME:

Vanessa V. Wertheim. PhD(c), MBA, RN

TITLE OF DISSERTATION:

The Effect of Organizational Commitment, Organizational Based Self Esteem and Work Engagement on Nurses' Perception of Medication Errors

DISSERTATION COMMITTEE:

Linda Urden, DNSc, RN. CNS, NE-BC,FAAN, Chairperson

Ann Mayo, DNSc, RN, FAAN, Member

Jane Grorges, phof Re Member 


\begin{abstract}
Background: Organizations rely on the accurate reporting of medication errors or omissions by bedside nurses to improve the medication delivery system in order to prevent further errors from occurring in the future. In a time where nurses are managing more complex patients with shorter lengths of stay, full engagement in the role is essential. Literature from other disciplines suggests that many factors can influence work engagement (Chughtai \& Buckley, 2011; Schaufeli, Salanova, González-Romá \& Bakker, 2002; Schaufeli \& Bakker, 2003). Two of these factors include organizational commitment and organizational-based self-esteem (Allen \& Meyer, 1990; Bowling, Eschleman, Wang, Kirkendall \& Alarcon, 2010).

The aim for this non-experimental, cross-sectional correlational study was to test an investigator developed conceptual model to determine if relationships exist between organizational commitment (OC), organizational-based self-esteem (OBSE), work engagement and nurses' perception of medication errors from a sample of RNs working in acute care facilities throughout the United States.
\end{abstract}

Methods: This study took place at two national nursing conferences in the United States during the fall of 2015 . Nurses spending at least $50 \%$ of their time at the bedside in an acute care facility were asked to participate. A paper survey measuring organizational commitment, organizational-based self-esteem, work engagement and nurse perception of medication errors was administered and results analyzed using SPSS version 23 and AMOS/mPlus software.

Results: The findings from this study indicated that there was a significant negative relationship between OBSE and nurses' perception of medication errors and that 
no statistically significant relationships existed between organizational commitment, nurse work engagement and nurses' perception of medication errors. Additionally, nurse and facility attributes did not statistically contribute to nurses' perception of medication errors with the independent variables accounting for only $18 \%$ of the variance.

Conclusion: This study is the first of its kind to evaluate the relationships between organizational commitment, nurse work engagement and OBSE on nurses' perception of medication errors The results of this study suggest that as OBSE increases, perceived medication error reporting decreases. Further research is needed to better understand OBSE in the nursing profession and its implications in other areas of nursing research. 
Copyright (C) 2016

Vanessa V. Wertheim

All Rights Reserved 


\section{Dedication}

This is dedicated to my amazing children - Ethan and Julia. I love you more than you will ever know and I hope that I have inspired you to never give up on your dreams. As long as you have Passion, Attitude and Drive (your PAD), you can achieve anything you set your mind to. Don't let anyone ever hold you back from achieving your goals and dreams in life - you can do it! 


\section{Acknowledgements}

To my “Dream Team” Dissertation Committee: Dr. Urden, Dr. Mayo and Dr. Georges - thank you so much for all of your time, patience and wisdom over the last few years. I would not be the nurse scholar I am today without you.

To all of my professors - I am forever grateful for the pearls of knowledge you have passed on to me during my time here at USD. I plan to continue gaining pearls and passing them along as learning is a lifelong endeavor.

To my truly amazing PhD gang - Julie, Jodi, Ginger, Mark, Marcel, Marissa, Valerie, Vicki, Kim, Mohammed, Monique, Tammie, Kathy, Essie and Teri - we made it! I am so blessed to have each of you in my life. We knew from the beginning that we were more than colleagues...we are truly a family.

To Eric - you have walked this journey with me since Day 1. Thank you for your support, encouragement, patience and understanding during one of the most challenging periods in my life. Thank you for being there every step of the way.

To my sister, Erica - thank you for always being there in the good times and bad. Sisters are forever...

To my parents - Look what your 29-week, $1100 \mathrm{~g}$ preemie did! Thank you for always believing in me. I grew up watching you build your own success through hard work and perseverance. You have inspired me to do the same. Thank you for that gift - I love you!

\section{"What you get by achieving your goals is not as important as what you become by achieving your goals." - Henry David Thoreau}




\section{TABLE OF CONTENTS}

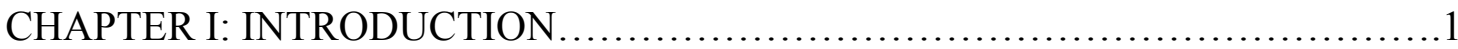

Background.......................................................................

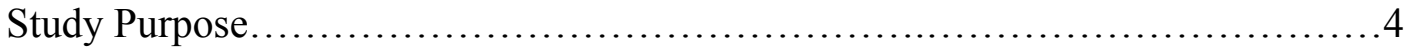

Specific Aims.......................................................4

Conceptual Model..............................................................5

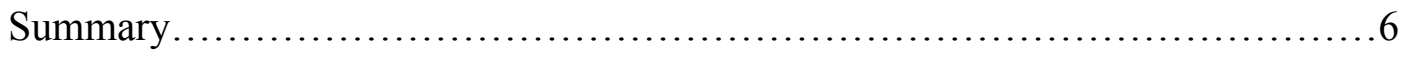

CHAPTER II: LITERATURE REVIEW ......................................

Introduction.................................................................

Organizational Based Self Esteem............................................................. 9

Organizational Commitment........................................... 12

Affective Commitment...........................................13

Normative Commitment............................................14

Continuance Commitment............................................. 14

Work Engagement................................................ 15

Nurse Perceptions of Medication Errors................................. 17

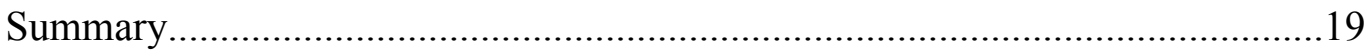

CHAPTER III: METHODS ....................................................20

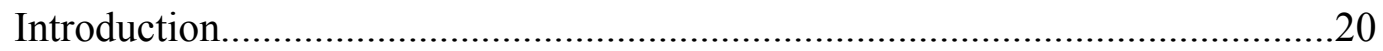

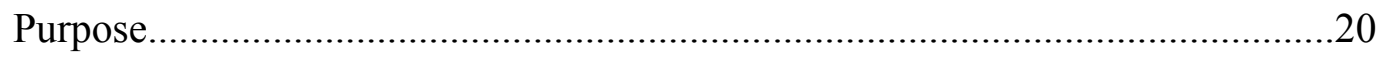

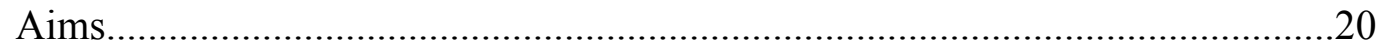

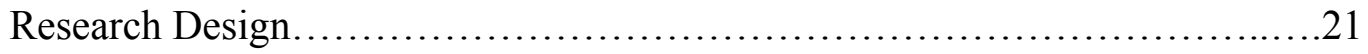

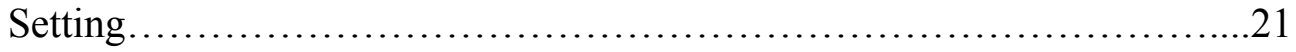




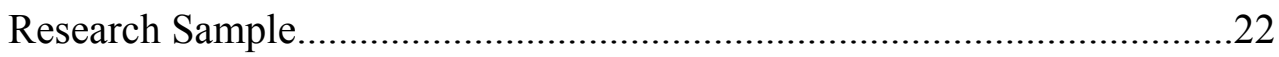

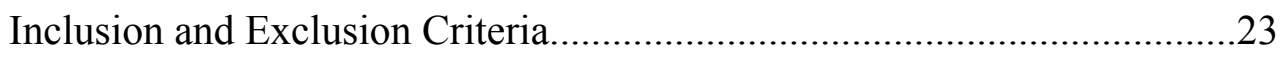

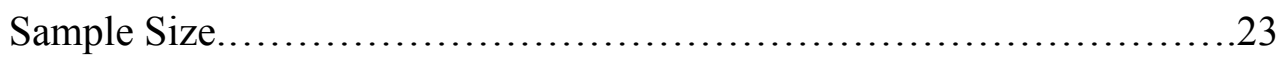

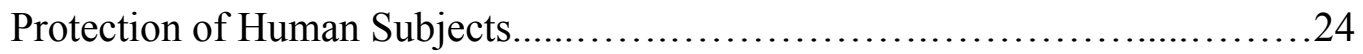

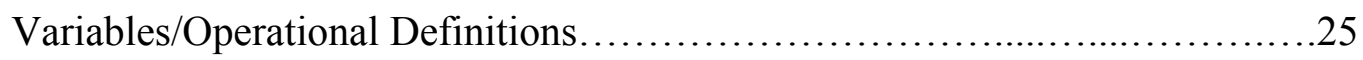

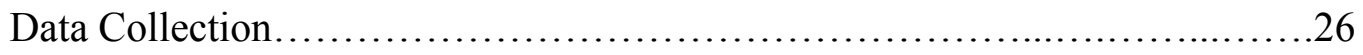

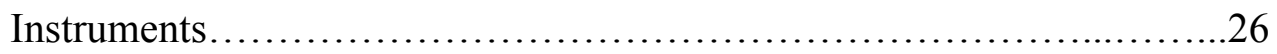

Registered Nurse and Facility Investigator Questionnaire...............26

Three-Component Model of Commitment Survey.................27

Organizational Based Self Esteem Questionnaire...................28

Utrecht Work Engagement Survey .................................29

Modified Gladstone Survey......................................29

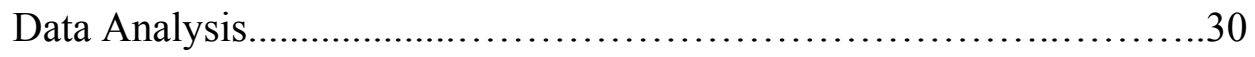

Confirmatory Factor Analysis..................................31

Structural Equation Modeling...................................... 31

Summary

CHAPTER IV: RESULTS.........................................................

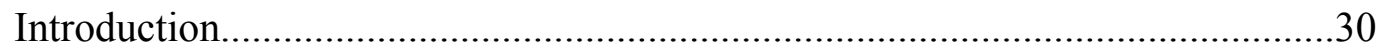

Description of Participant Sample.....................................................................

Nurses' Perception of Medication Errors ...............................................................35

Causes of Medication Errors............................................35

Drug Error Scenarios................................................... 38

Nurses' Views on Reporting Errors.......................................................41 


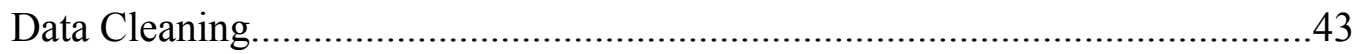

Crombach's Alpha...................................................43

Detailed Results.........................................................44

Confirmatory Factor Analysis..................................45

Structural Equation Modeling.........................................................46

Model Specifications....................................................47

Composite Reliability.................................................48

Factor Correlations .............................................49

Regression Estimates.......................................49

Multiple Regression................................................51

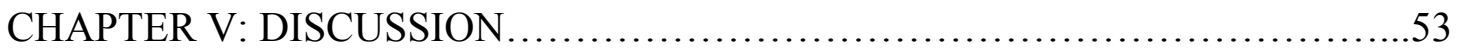

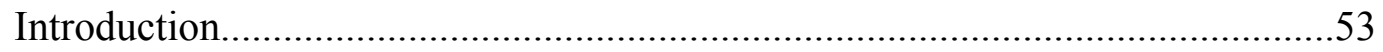

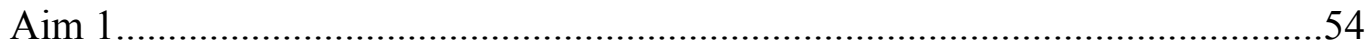

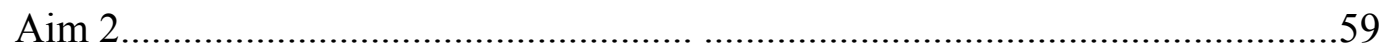

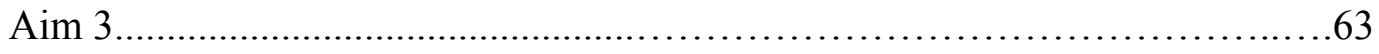

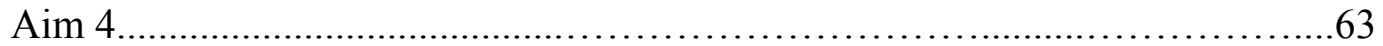

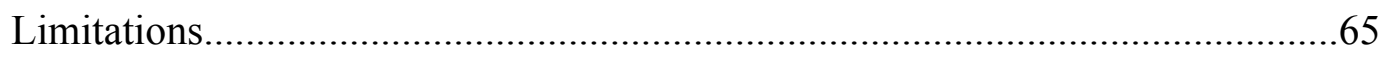

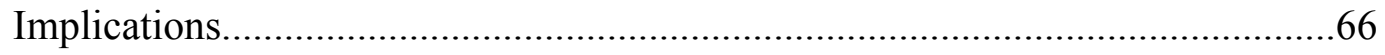

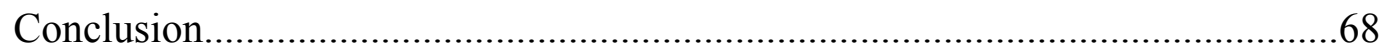

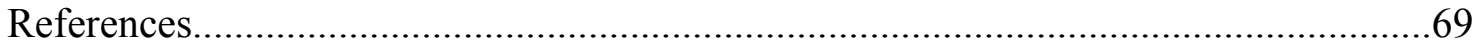

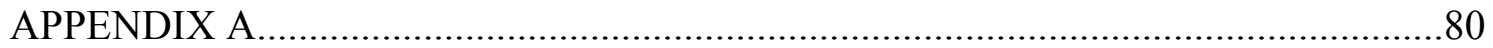

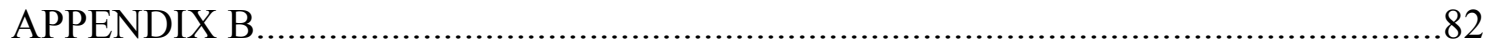

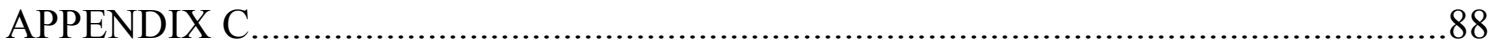


APPENDIX D

APPENDIX E.

APPENDIX F.

\section{List of Tables}

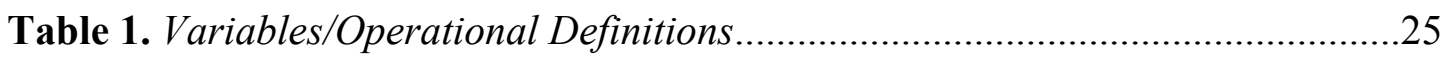

Table 2. Frequencies and Percentages for Demographic Information......................32

Table 3. Means and Standard Deviations for Demographic Variables......................35

Table 4. Frequencies and Percentages of Possible Medication Error Causes...........36

Table 5. Frequencies and Percentages for Medication Error Scenarios...................40

Table 6. Frequencies and Percentages for Personal Views on Reporting Medication Errors.

Table 7. Cronbach's Alpha Reliability for Composite Scores. 44

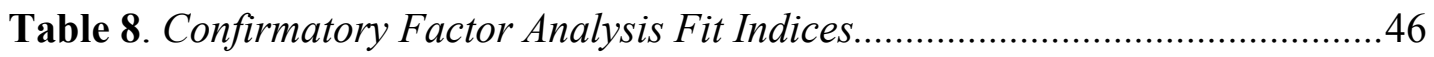

Table 9. Structural Equation Model Fit Indices...............................................48

Table 10. Composite Reliability for Each Construct............................................49

Table 11. Factor Correlations for Independent Measures...................................49

Table 12. Standardized Regression Paths................................................50, 61

Table 13. Multiple Regression of Organizational Characteristics and Nurse Attributes on Perception of Medication Errors. 52,65

\section{List of Figures}

Figure 1. Proposed Conceptual Structural Equation Model. $.7,45,60$

Figure 2. Structural Equation Model with Regression Weights. $.51,62$ 


\section{List of Appendices}

Appendix A. Demographic Questionnaire.................................................8

Appendix B. Combined Survey Instrument .............................................8

Appendix C. Instrument Permissions ......................................................85

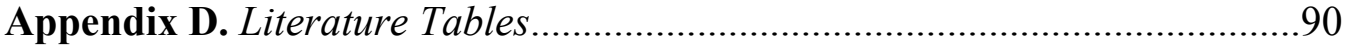

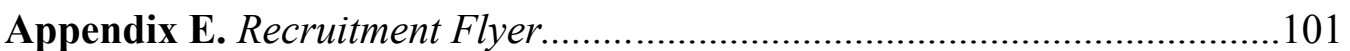

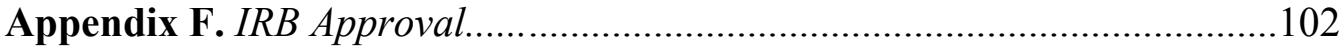




\section{Chapter 1}

\section{Introduction}

Adoption of the Affordable Care Act and major changes to Medicare reimbursement has changed the way hospitals do business. Nurses have taken on more responsibility with less available resources, which can severely impact engagement in their role, organization and profession (Kutney-Lee et al., 2009). Organizations cannot afford to have a disengaged nursing workforce. Previous studies highlight a direct association between nurse engagement and patient complications and mortality (Aiken et al., 2012; Duffield et al., 2011; Needleman, Buerhaus, Mattke, Stewart \& Zelevinsky, 2002). These studies reveal the association between poor quality outcomes on nurse sensitive indicators such as Central Line-associated Bloodstream Infections (CLABSI) and low nurse engagement (Kavanagh, Cimiotti, Abusalem \& Coty, 2012). In fact, organizations with low nurse engagement pay out significantly more in malpractice claims than organizations with high nurse engagement (Charmel \& Frampton, 2008).

Adverse drug events (ADEs) due to medication errors further contribute to the rising cost of healthcare. According to the 2001 Institute of Medicine (IOM) report To Err is Human: Building A Safer Health System, roughly two out of every 100 admissions experience a preventable $\mathrm{ADE}$, at an expense of approximately $\$ 2$ billion annually (Kohn, Corrigan \& Donaldson, 2000).

Organizations rely on the accurate reporting of medication errors or omissions by bedside nurses to improve the medication delivery system - prescription to administration, in order to prevent further errors from occurring in the future. 
Unfortunately, many nurses do not report medication errors either for fear of disciplinary action or for lack of understanding of what constitutes a medication error (Hewitt, 2010). With higher acuity patients and less resources for nurses, this continues to be a significant topic for the nursing profession.

This chapter will introduce the reader to the purpose of this study, the specific aims for the study, as well as the proposed theoretical model associated with the study.

\section{Background}

Work engagement has been a heavily researched topic in recent nursing literature. In a time where nurses are managing more complex patients with shorter lengths of stay, full engagement in the role is essential. Literature from other disciplines suggests that many factors can influence work engagement (Chughtai \& Buckley, 2011; Schaufeli, Salanova, González-Romá \& Bakker, 2002; Schaufeli \& Bakker, 2003). Two of these factors include organizational commitment - the emotional attachment that an employee has to an organization and organizationalbased self-esteem - how an employee believes that he or she provides a valuable contribution to an organization (Allen \& Meyer, 1990; Bowling, Eschleman, Wang, Kirkendall \& Alarcon, 2010).

Organizational commitment has been a topic of interest since the 1950s. A pioneer in the area of commitment, Becker (1960) identified the challenges associated with defining organizational commitment and proposed one of the first theories on the concept of commitment. Since Becker's 1960 landmark paper, many psychologists 
and sociologists have refined the concept of commitment and proposed their own theories. The three-component model of commitment proposed by Meyer and Allen (1991), along with the instrument based on their concept will be used for this research study. Further discussion of the Meyer et al. three-component model will take place in chapter two.

Organizational-Based Self-Esteem (OBSE), first introduced by Pierce, Gardner, Cummings and Dunham (1989), found its roots in Korman's (1970) self consistency-theory. The theory is based on the belief that employees wish to uphold a consistent level of self-esteem and will shape their attitude and performance in the workplace to reflect their view of themselves (Bowling et al., 2010).

Over the past 25 years, Pierce and colleagues have defined, developed and validated a measurement tool designed to measure OBSE. With only a small amount of literature available identifying OBSE in the nursing workforce, this is an opportunity to expand this concept and tool into the nursing profession. Further discussion of the concept of OBSE will be discussed in chapter two.

Bedside nurses are the primary administrators of medication in the acute care setting. The administration of medication to patients places a significant amount of responsibility and liability on the nurse (Gladstone, 1995). In order to properly administer medication, the nurse at a minimum must first understand the mechanism of action, the proper route, the side effects, the timing of the dose as well as the correct dose for the type of patient treated with the medication (O'Shea, 1999). As stated earlier, many nurses do not report medication errors either for fear of disciplinary action or for lack of understanding of what constitutes a medication error 
(Hewitt, 2010). At least five years before the IOM report came out identifying the importance of reconciling medication errors, Gladstone (1995) accurately identified the problem within our profession and presented factors that may contribute to the errors and underreporting. Despite our effort to reduce medication errors, adverse drug events continue to cause significant harm and deaths without regard to age, sex, race or location (Hewitt, 2010). In-depth discussion on this topic will be continued in chapter two.

\section{Study Purpose}

The purpose of this non-experimental, cross-sectional correlational study was to test an investigator developed conceptual model to determine if relationships exist between organizational commitment (OC), organizational-based self-esteem (OBSE), work engagement and nurses' perception of medication errors from a sample of RNs who work in a acute care facilities throughout the United States. Through an investigator-designed conceptual model, it was hypothesized that OC and OBSE will have a positive effect on nurse work engagement and perception of medication errors. The specific aims for the study are as follows:

\section{Specific Aims}

1. Describe organizational commitment (affective, normative and continuance commitment), OBSE, work engagement (vigor, absorption and dedication), organizational characteristics (facility type; magnet status; size and geographic location), nurse characteristics (age; education; unit type, hours worked and role; and tenure in organization and profession), and nurses' perception of medication errors. 
2. Test the conceptual model that relationships are present between organizational commitment (affective, normative and continuance commitment), OBSE, work engagement (vigor, dedication and absorption) and nurses' perception of medication errors (Figure 1).

3. Test the relationship of organizational characteristics (facility type; magnet status; size and geographic location) on nurses' perception of medication errors.

4. Test the relationship of nurse attributes (age; education; unit type, hours worked and role; and tenure in organization and profession) on nurses' perception of medication errors.

\section{Conceptual Model}

The proposed conceptual model for this study was a blending of concepts from Meyer and Allen's three-component model of organizational commitment, Pierce, Gardner, Cummings and Dunham's organizational based self esteem concept, and Schaufeli and Bakker's concept of work engagement (see Figure 1). The conceptual model serves to describe the proposed relationships between the variables of organizational commitment, OBSE and work engagement on nurses' perception of medication errors. Additionally, this study serves to determine, which, if any, demographic (nurse or organizational) variables have a significant influence on the proposed model.

Chapter two will address in more detail the concepts outlined in the proposed conceptual model and chapter three will further define the variables to be used in the study. 


\section{Summary}

Mitchell Rabkin, M.D., former president of Beth Israel Hospital, once wrote: "Hospitals are primarily nursing institutions, where 'doctoring' is episodic and hospital success is due to a colleagueship and partnership between physician and nurse" (Fasoli, 2010). In our ever evolving and challenging healthcare environment, it is imperative that we create an environment where all disciplines are engaged in their role and that all patients receive the best possible care. Work engagement, organizational commitment and organizational based self esteem can play a role in determining how well nurses are caring for our patients. It is anticipated that this study will help highlight these relationships and provide insight into this understudied topic of nursing.

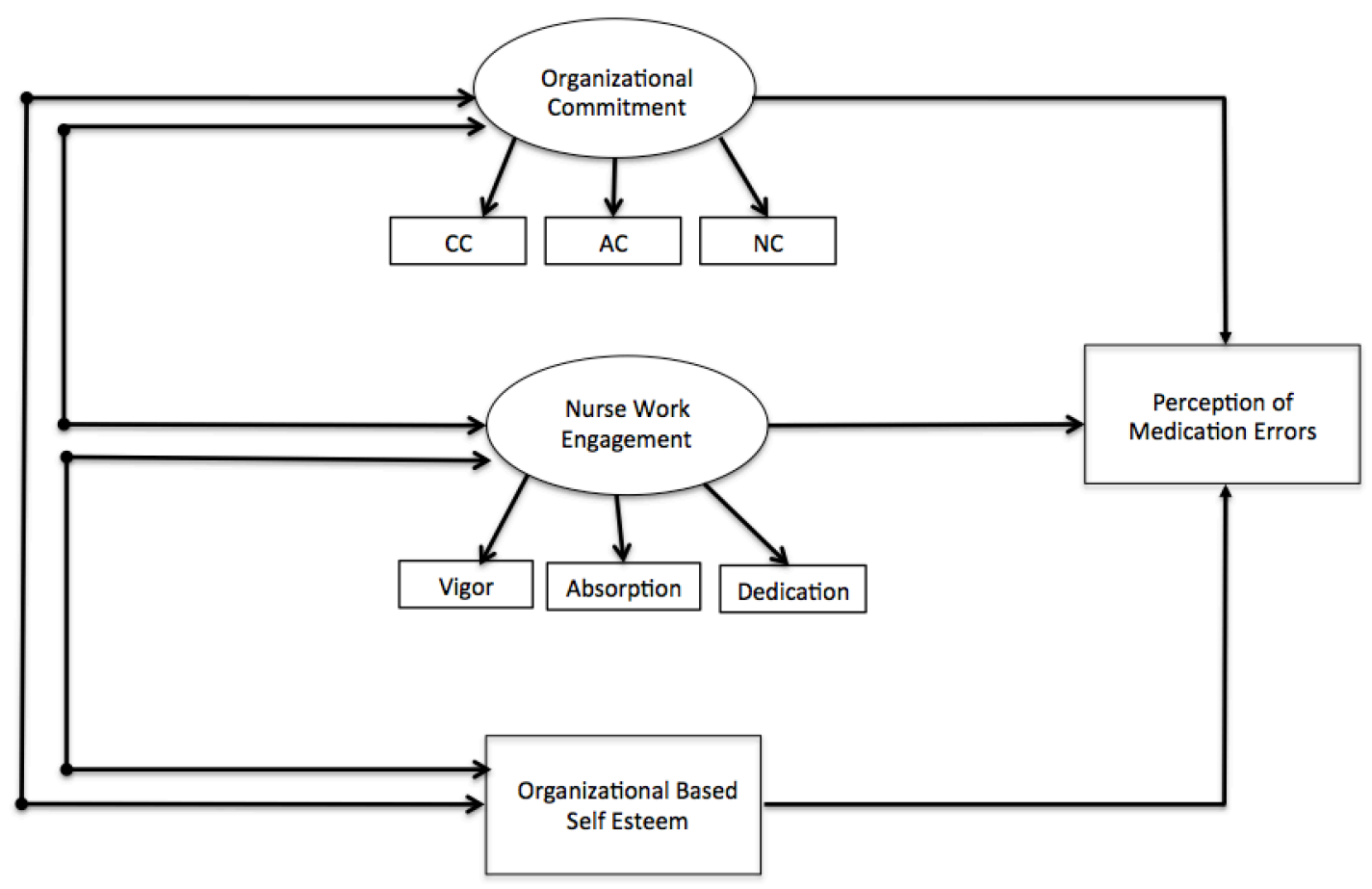

Figure 1 - Proposed Conceptual Structural Equation Model 


\section{Chapter 2}

\section{Literature Review}

\section{Introduction}

In this chapter, a summary of the literature regarding organizational-based self-esteem, organizational commitment, work engagement and perception of medication errors will be presented. A comprehensive literature search was completed using the Cumulative Index to Nursing and Allied Health Literature (CINAHL), Google Scholar, and references obtained from cited articles. Key words used in the search included "OBSE”, “Organizational-Based Self-Esteem”, “Organizational Commitment”, "Work Engagement”, "Nursing”, "Nursing Profession", "Nursing Engagement”, "Medication Error”, "Nursing Medication Error" and "Perception of Medication Error".

\section{Organizational Based Self Esteem}

As mentioned in chapter one, OBSE, first introduced by Pierce et al. (1989), found its roots in Korman's (1970) self consistency-theory. The theory is based on the belief that employees wish to uphold a consistent level of self-esteem and will shape their attitude and performance in the workplace to reflect their view of themselves (Bowling et al., 2010). Prior to the development of the concept of OBSE, psychologists and sociologists were at a loss on how to accurately study self-esteem in the workplace. Pierce et al. (1989) discuss their rationale for the concept:

Many of the constructs that are traditionally employed in organizational paradigms, such as turnover, climate, commitment, and citizenship, are oriented toward employees and their role within a total organization, and it is at the total work 
environment level of analysis that there is a need for an appropriate measure of selfesteem. To our knowledge, however, no construct-validated measure of self-esteem exists that is anchored in an organizational frame of reference, even though many important constructs in the organizational sciences are organization-based. We directed the present research effort toward the development and initial validation of such a measure of self-esteem, hoping that such a measure will better enable researchers to examine the effects of self-esteem in relation to other organizationbased constructs. (p.624)

Pierce and his colleagues believed that by using Korman's self consistency theory as the foundation for their OBSE construct, they could make a case that one's overall self-esteem - global self esteem can be related to task-specific self esteem that is, individual experiences within an organization that can determine an individuals organizational-based self-esteem (Pierce et al., 1989). Thus, OBSE can be defined as the degree to which an employee feels that he/she is a capable, significant and worthy member of an organization (Pierce et al., 1989; Peirce \& Gardner, 2004; Gardner, Huang, Niu, Pierce \& Lee, 2014; Chen et al., 2015).

Over the past 25 years, OBSE has been researched in various disciplines around the world. Researchers in business administration, industrial and organizational psychology and sociology have tested the concept and measure to enrich their areas of study. Only one study, however, has been found to date using OBSE as a measure for bedside nurses (Chen et al., 2015). Chen et al. (2015) utilized the OBSE construct and instrument to determine the factors associated with 
Taiwanese nurses' intention to stay in a Taiwan hospital. Chen et al. (2015) found a significant correlation between intention to stay and high OBSE.

Although no current studies could be found for using the OBSE construct on nurses in the United States, one study on Emergency Medical Technicians (EMTs) researched the effect of OBSE on career commitment and quality of care (Carson, Carson, Lanford, \& Roe, 1997). Carson and her colleagues found that EMTs with high OBSE were more committed to their career and valued providing quality care as opposed to those EMTs with low OBSE (Carson et al., 1997).

Other studies in OBSE literature focused on topics such as pay level and its impact on OBSE and performance (Gardner, van Dyne \& Pierce, 2004), OBSE and narcissism in organizations (Gardner \& Pierce, 2011), organizational uncertainty and the moderating effects of OBSE (Hui \& Lee, 2000), and the concept of ‘organizational care' and its influence on OBSE (McAllister \& Bigley, 2002).

Additionally, two studies focused on OBSE and the supervisor-subordinate role. Sekiguchi, Burton and Sablynski (2008) focused on the concept of job embeddedness and its relationship to OBSE and Panaccio and Vandenberghe's (2011) study focused on role clarity, OBSE and commitment to supervisors. One study by Lapointe, Vandenberghe and Panaccio (2011) combined the factors of organizational commitment and OBSE in observing emotional exhaustion and turnover. The concept of organizational commitment will be addressed next.

\section{Organizational Commitment}

As introduced in chapter one, the concept of commitment has had a great deal of attention since the 1950s. A pioneer in the area of commitment, Becker (1960) 
identified the challenges associated with defining organizational commitment and proposed one of the first theories on the concept of commitment. Becker's theory stemmed from the idea that employees are committed because they make "side bets", or hidden investments by remaining in an organization (Becker, 1960; Powell \& Meyer, 2003; Cohen, 2007). Meaning, over a period of time, an employee has made a number of investments such as time, effort and tenure in an organization. If the employee were to leave, these investments would be lost. For some employees, the potential loss of these investments and lack of alternatives to make up for the loss, keep them committed to their organization (Becker, 1960; Powell et al., 2003; Cohen, 2007).

Since Becker's (1960) introduction of his concept and theory on commitment, many researchers have attempted to expand and redefine the concept into organizational and sociological research. Kanter (1968), as part of her dissertation research, focused on the idea that employee commitment can be broken down into three types: cognitive-continuance commitment - commitment to social roles, cathectic-cohesion commitment - attachment to social relationships, and evaluativecontrol commitment - commitment to the norms or "inner convictions that morally obligate an individual” (p.501). Other researchers have defined organizational commitment as “...the relative strength of an individual's identification with and involvement in a particular organization" (Mowday, Steers \& Porter, 1979, p.226; Meyer \& Herscovitch, 2001, p.302), “...the totality of normative pressures to act in a way which meets organizational goals and interests." (Weiner, 1982, p.421; Meyer et 
al., p.302) and "...a bond or linking of the individual to the organization." (Mathieu \& Zajac, 1990, p.171; Meyer et al., 2001, p.302).

In the mid 1980s Meyer and Allen refined Becker's side-bet theory and built on Kanter's (1968) commitment types using social norms, believing that side-bets are actually attitudes toward commitment due to the belief that employees show “awareness" of costs associated with leaving (Meyer \& Allen, 1984; Ko, Price \& Mueller, 1997; Powell et al., 2003; Cohen, 2007). To this extent, Meyer and Allen sought to measure the employee's perception as to the amount and degree of side-bets he or she has made (Meyer et al., 1984).

In the early 1990s, Meyer and Allen redefined organizational commitment as “...a psychological state that binds the individual to the organization (i.e., makes turnover less likely)" and proposed a three-component model of conceptualization of organizational commitment (Allen \& Meyer, 1990, p.14). Meyer and Allen's model is considered by many to be the leading model in organizational commitment research (Solinger, van Olffen \& Roe, 2008). The three components in their model are affective commitment, normative commitment and continuance commitment. Affective Commitment

Affective Commitment, the first of the three-component model, is based on the emotional attachment that an employee has with the organization. With this component of commitment, the employee wants to stay with the organization based on his or her emotional attachment and identification with the organization (Allen et al., 1990; Allen \& 
Meyer, 1996; Irving, Coleman \& Cooper, 1997; Meyer, Stanley, Herscovitch \& Topolnytsky, 2002; Erdheim, Wang \& Zickar, 2006). This emotional attachment stems from a feeling of comfort in the organization and a sense of purpose or job challenge (Meyer, Allen \& Gellatly, 1990).

Normative Commitment

Normative Commitment, the second component of the three-component model, is based on the theory that employees feel a sense of obligation to their organization and stay because it is the right thing to do (Allen et al., 1990; Allen et al., 1996; Meyer \& Parfyonova, 2010). Cohen (2007) took it one step further by adding "normative commitment is affected in the main by socialization and/or culture prior to entry into an organization" (p.340). In other words, the values and beliefs an employee brings into the organization will drive their commitment to the organization.

\section{Continuance Commitment}

Continuance Commitment, the final component of the three-component model, is based on the costs associated with leaving an organization (Allen et al., 1990; Allen et al., 1996). In other words, an employee may want to leave an organization, but realize that the costs associated with leaving, such as time invested, position attained, salary and lack of alternatives, are too high (Meyer et al., 1990). Thus, the employee stays committed to an organization because they feel that they have to stay. This component of commitment stems from Becker's (1960) "side-bet" theory of commitment (Cohen, 2007).

Organizational Commitment in Nursing 
Organizational commitment has been a topic of interest in the nursing profession in recent years. Due to the potential nursing shortage of experienced nurses in the United States and internationally, a majority of research on this topic focuses on the relationship between organizational commitment and nursing turnover (De Gieter, Hofmans \& Pepermans, 2011; Carter \& Tourangeau, 2012). For this study, Allen and Meyer's model will be used to determine the relationship between organizational commitment and work engagement, and subsequently its impact on nurses' perception of medication errors.

\section{Work Engagement}

Work engagement is a broad term that has been subject to many variations in terminology and definitions. Fasoli (2010) defines work engagement as "an employee's psychological commitment to one's job and workplace” (p.19). This sounds very similar to our previous definition of affective commitment. It makes sense, though, to consider that to be engaged in one's job, an employee should have an emotional attachment to their work.

Arnold Bakker, a leader in engagement research, defines individuals who are engaged in their work as " [those with] positive emotions, including happiness, joy, enthusiasm; [who] experience better health; create their own job and personal resources; and transfer their engagement to others." (Bakker \& Demerouti, 2008, p.215). In addition, Schaufeli \& Bakker (2004) define work engagement as "a positive, fulfilling, work-related state of mind that is characterized by vigor, dedication, and absorption...[and] engagement refers to a persistent and pervasive 
affective-cognitive state that is not focused on any particular object, event, individual, or behavior.”(p.295)

Schaufeli et al. (2004) operationalized their definition of work engagement into the three dimensions in the Utrecht Work Engagement Scale (UWES). The three dimensions are vigor, dedication and absorption. The first dimension, vigor, is described as the energy and enthusiasm one brings to his/her work, and the resilience and persistence to overcome work-related challenges (Schaufeli et al., 2004; SpenceLaschinger, Wilk, Cho \& Greco, 2009). The second dimension, dedication, is described as the pride, inspiration and sense of significance one brings to his/her work (Schaufeli et al., 2004; Spence-Laschinger et. al, 2009). The final dimension, absorption, refers to the feeling one gets when time passes quickly while immersed in his/her work (Schaufeli et al., 2004; Spence-Laschinger et al., 2009).

Work engagement has been studied extensively in the nursing workforce. Topics such as empowerment, experience and work engagement (Laschinger, Wilk, Cho \& Greco, 2009); moral distress, critical reflective practice and work engagement (Lawrence, 2011); drivers of nurse work engagement (Rivera, Fitzpatrick \& Boyle, 2011); predictors of work engagement among medical-surgical nurses (Simpson, 2009); work engagement and patient-centered care (Abdelhadi \& Drach-Zahavy, 2011) and work engagement related to nurse retention (Tillott, Walsh \& Moxham, 2013) are a sampling of the topics found in nursing literature.

Although a significant amount of research is occurring on work engagement, only $18 \%$ of the nursing workforce is actively engaged in their work, leaving $82 \%$ that are not engaged or actively disengaged (Blizzard, 2002; Fasoli, 2010). Clearly, 
work engagement in the nursing profession continues to be an unresolved issue. This study aims to add further insight into the work engagement literature and bring our profession closer to having a more engaged nursing workforce.

\section{Nurse Perceptions of Medication Errors}

Bedside nurses are the primary administrators of medication in the acute care setting. The administration of medication to patients places a significant amount of responsibility and liability on the nurse (Gladstone, 1995). Although many active and latent system failures must occur in order for a medication error to reach a patient, as the administrator of the medication, nurses are held accountable (Gladstone, 1995; Fry \& Dacey, 2007; Ulanimo, O’Leary-Kelley \& Connolly, 2007; Mahmood, Chaudhury \& Valente, 2011; Maiden, Georges \& Connelly, 2011).

The National Coordinating Council for Medication Error Reporting and Prevention (NCCMERP) provides the most succinct definition of medication error found to date:

"Any preventable event that may cause or lead to inappropriate medication use or patient harm while the medication is in the control of the healthcare professional, patient, or consumer. Such events may be related to professional practice, prescribing; order communication; product labeling; packaging and nomenclature; compounding; dispensing; distribution; administration; education; monitoring; and use.” (National Coordinating Council for Medication Error Reporting, 2015, para.1) 
Although the definition provided by NCCMERP is comprehensive, a majority of the studies on nurses' perception of medication errors found that nurses interpret or redefine what constitutes a medication error based on their current situation (Ulanimo et al., 2007; Osborne et al., 1999; Mayo and Duncan, 2004; Hewitt, 2010). For organizations that rely on accurate self-reporting of medication errors by bedside nurses, this can lead to misleading, inaccurate and incomplete data when attempting to improve the medication delivery system (Hewitt, 2010).

According to Osborne et al. (1999) an estimated 25\% of all medication errors are reported. This leaves $75 \%$ of all medication errors unreported. Redefining and/or self-interpreting medication errors are only two reasons why medication errors go unreported. Many nurses do not report errors for fear of the psychological, professional and financial repercussions for doing so (Gladstone, 1995; Osborne et al., 1999; Mayo et al., 2004; Ulanimo et al., 2007).

Nurses go into nursing to care for the sick. When a medication error occurs, it goes against the fiber of our profession. The psychological toll and loss of self-esteem and confidence the nurse experiences can be personally and professionally paralyzing. Although medication errors have been studied since the 1960 s, they continue to occur (Cohen, M., 2007). With nurses on the front lines, this research study hopes to add to current literature and provide another angle to view this important area of nursing science.

\section{Summary}

Gladstone (1995) points out that "In the relationship between patient and nurse, there is an implicit trust that the nurse will always be working for the well- 
being and benefit of the patient...this trust is violated when a nurse makes a drug administration error" (p.628). Medication errors continue to harm our patients and rattle nurses practicing at the bedside. As stated in chapter one, according to the 2001 Institute of Medicine (IOM) report To Err is Human: Building A Safer Health System, roughly two out of every 100 admissions experience a preventable ADE, at an expense of approximately $\$ 2$ billion annually (Kohn et al., 2000). This study aims to add further insight into the potential relationship of organizational commitment and OBSE and its impact on nurse work engagement and perception of medication errors. Chapter three will explain the design of the study, the research sample and setting along with the variables, instruments and data collection methods. 


\section{Chapter 3}

\section{Methods}

\section{Introduction}

This chapter will provide an outline of the methodology for the research study, including: purpose; research design and sample; protection of human subject considerations; variables and operational definitions; and data collection instruments and analysis.

\section{Purpose}

The purpose of this non-experimental, cross-sectional correlational study was to test an investigator developed conceptual model to determine if relationships exist between organizational commitment (OC), organizational-based self-esteem (OBSE), work engagement and nurses' perception of medication errors from a sample of RNs who work in a acute care facilities throughout the United States. Through an investigator-designed conceptual model (see Figure 1), it was hypothesized that OC and OBSE will have a positive effect on nurse work engagement and perception of medication errors. The specific aims for the study are as follows:

1. Describe organizational commitment (affective, normative and continuance commitment), OBSE, work engagement (vigor, absorption and dedication), organizational characteristics (facility type; magnet status; size and geographic location), nurse characteristics (age; education; unit type, hours worked and role; and tenure in organization and profession), and nurses' perception of medication errors. 
2. Test the conceptual model that relationships are present between organizational commitment (affective, normative and continuance commitment), OBSE, work engagement (vigor, dedication and absorption) and nurses' perception of medication errors (Figure 1).

3. Test the relationship of organizational characteristics (facility type; magnet status; size and geographic location) on nurses' perception of medication errors.

4. Test the relationship of nurse attributes (age; education; unit type, hours worked and role; and tenure in organization and profession) on nurses' perception of medication errors.

\section{Research Design}

This non-experimental, cross-sectional correlational study examined the relationships between affective commitment (AC), normative commitment (NC), continuance commitment (CC) (which make up OC), OBSE and vigor, dedication and absorption (which make up work engagement) on nurses' perception medication errors. According to Polit and Beck (2012), non-experimental correlational studies describe the relationship between variables without the ability to ethically manipulate the variables.

\section{Setting}

This study took place during two different national conferences occurring in two different United States locations in the fall of 2015. Exhibitor space was acquired for each conference as a platform to carry out sample recruitment, survey distribution and survey collection. The first conference was the annual American Nurses 
Credentialing Center (ANCC) National Magnet Conference that occurred October 79, 2015 in Atlanta, GA. The second conference was the annual National Association of Neonatal Nurses (NANN) conference that occurred October 22-25, 2015 in Dallas, TX.

Research Sample

The research sample for this study was a purposive, non-randomized sample of RNs attending two national professional conferences in Atlanta, GA and Dallas, TX. Registered nurses meeting the inclusion criteria were solicited to complete the survey. Recruitment of the research sample took place through the use of exhibitor space during brakes, lunches and free time between sessions at the professional conferences. The exhibit booth had information available describing the research study, consent forms and the research survey.

As a secondary measure to collect data, attendance at local chapter meetings (in California) as well as mailings to members of the following professional groups: American Association of Critical Care Nurses, Academy of Medical Surgical Nurses and the National Association of Neonatal Nurses would have been requested if the sample size for the study was not met. As a "thank you" for the time spent on the survey, nurses completing the survey received a give-away gift valued at \$5 USD. Inclusion and Exclusion Criteria

Registered Nurses (RNs) working in an acute care setting were invited to participate in the study. Exclusion criteria included RNs working in home health care, nursing homes, as a private duty nurse, as a travel nurse, or working as a nurse outside of the United States. 
Sample Size

Structural Equation Modeling (SEM) was used in the study to address the specific aims stated at the beginning of this chapter. Determining appropriate sample sizes for studies using SEM can be challenging. As highlighted by Wolf, Harrington, Clark \& Miller (2013):

"One of the strengths of SEM is its flexibility, which permits examination of complex associations, use of various types of data (e.g., categorical, dimensional, censored, count variables), and comparisons across alternative models. However, these features of SEM also make it difficult to develop generalized guidelines regarding sample size requirements." (p.914).

Sample size is generally determined by model complexity. Since there is no "onesize-fits-all" approach to determining sample size using SEM, the $N: q$ rule will be used to determine sample size for this study (Kline, 2011). The $N: q$ rule is the ratio of cases $(\mathrm{N})$ to the number of model parameters that require statistical estimates $(\mathrm{q})$. The $\mathrm{N}: \mathrm{q}$ rule is used for SEM research that intends to use the maximum likelihood (ML) method of estimation, which is most often used in SEM (Kline, 2011).

A widely accepted N:q ratio in SEM is 20 cases for every 1 model parameter, or $\mathrm{N}: \mathrm{q}=20: 1(\mathrm{Kline}, 2011)$. Using this ratio, the sample size needed for this study with the ML method, is 380 nurses $(20$ cases: 19 parameters $=20 \times 19=380)($ see Table 1 for list of parameters). Further discussion of SEM will take place in the data analysis section. 


\section{Protection of Human Subjects}

In 1974, the National Commission for the Protection of Human Subjects of Biomedical and Behavioral Research was created to protect individuals participating in human subjects research. The commission developed guidelines to assist researchers in following basic ethical principles of respect of persons (autonomy), beneficence and justice (US Department of Health and Human Services, 1979). These guidelines are followed today through the use of individual Institutional Review Boards (IRB). It is the responsibility of individual IRBs to provide oversight, using established federally mandated guidelines, in order to guide researchers conducting human subject research. For this research study, IRB consent for oversight was obtained from the University of San Diego Institutional Review Board.

Protection of confidentiality and anonymity during and after data collection included coding the survey and demographic questionnaire with a de-identified numeric coding system. All surveys and questionnaires are currently kept in a locked filing cabinet that only for which the research team has access. No electronic copies of the surveys or questionnaires have been made. Potential risks to participants in the study included loss of confidentiality and evoking strong feelings about the topics questioned in the survey.

\section{Variables/Operational Definitions}

\section{Variables/Operational Definitions}

Variables/Operational Definitions for the study are listed in Table $\mathbf{1 .}$ 


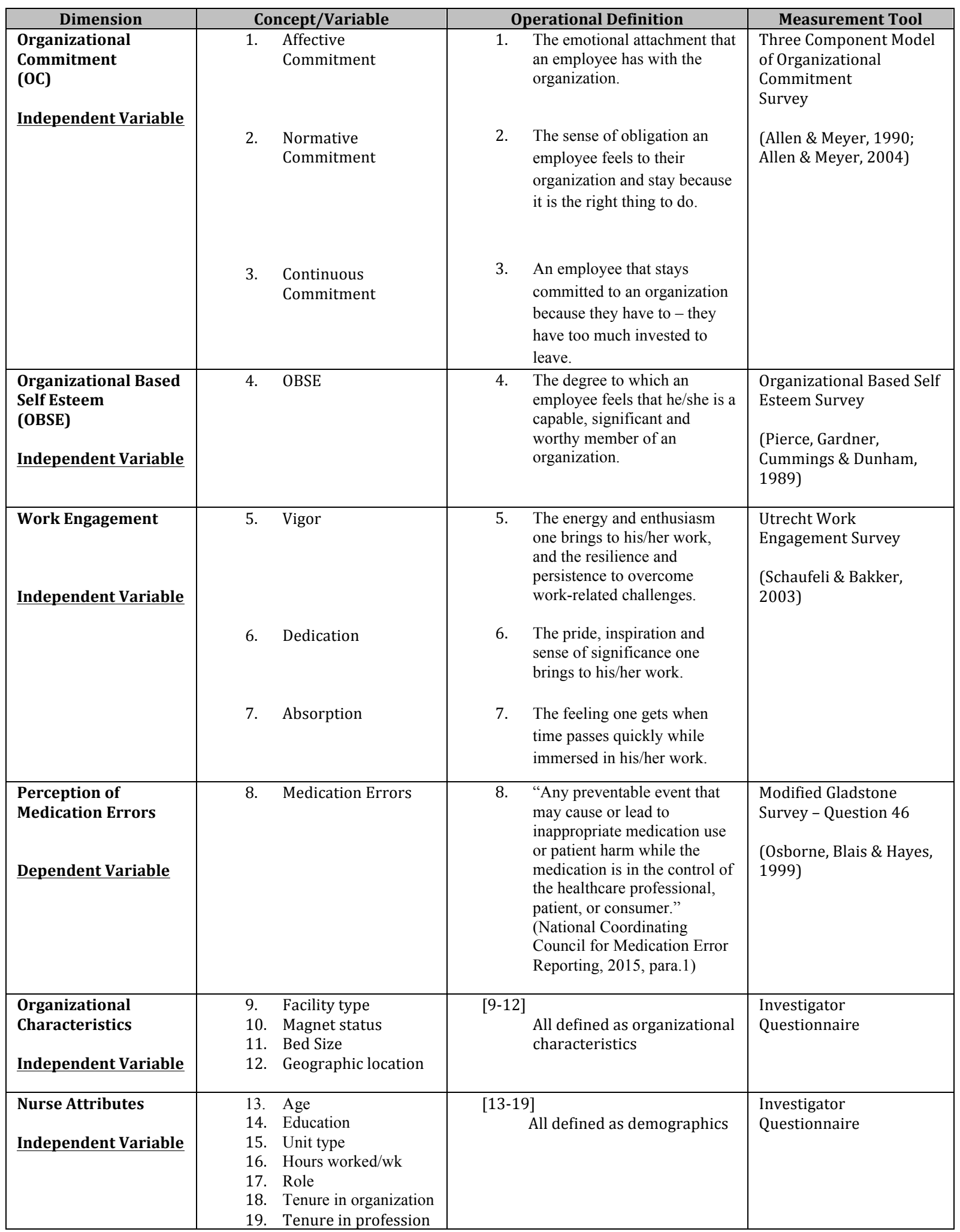

Table 1. Variables and Operational Definitions 


\section{Data Collection}

Measurement tools for the study included an investigator designed nurse and facility demographic questionnaire, the 18-item Three-Component Model of Employee Commitment, the 10-item Organizational Based Self Esteem Scale, the 17item Utrecht Work Engagement Scale and the 14-Item Modified Gladstone. All instruments except for the demographic questionnaire and Modified Gladstone were measured on a five-point Likert scale. All instruments exhibited acceptable reliability with Cronbach $\alpha$ exceeding .70 for all scales. All instruments were presented in paper-pencil format and took 20-25 minutes to complete.

\section{Instruments}

Registered Nurse and Facility Investigator Questionnaire

In order to properly determine the impact of nurse attributes or facility characteristics on organizational commitment, OBSE, work engagement and nurses' perception of medication errors, the investigator had created a 13-item demographic questionnaire distributed with the four-instrument survey for the study. Respondents were asked to provide personal information including: age, education, unit type, hours worked per week, role in unit and tenure at facility and in profession. In addition, respondents were asked to provide information on their facility, including: facility type, magnet status, bed size and geographic location (state and rural/urban) (See Appendix A).

\section{Three-Component Model of Employee Commitment Survey}

The three-component model of employee commitment developed by Allen and Meyer in 1990 is considered the "gold standard" in commitment research 
(Solinger et al., 2008). The survey consists of three scales, each measuring one component of the three-component model. All three scales include six items, and are all measured on a five-point disagree-agree Likert response scale ( 1 = Strongly Disagree; 5 = Strongly Agree). Some items are reversed keyed to prevent response bias. There was a total of 18 items for this instrument, six items for each scale.

The first scale is the affective commitment scale (ACS). As reviewed in chapter two, affective commitment is based on the emotional attachment that an employee has with the organization. Examples of statements on this scale include: "I would be very happy to spend the rest of my career with this organization"; "This organization has a great deal of personal meaning for me"; I do not feel like "part of the family' at my organization"; and "I do not feel 'emotionally attached' to this organization". Internal reliability for this scale has ranged from coefficient $\alpha=.79$ .89 , with a majority of the studies reporting coefficient $\alpha=.84-.89$ range (Allen et al., 1996; Powell et al., 2004).

The second scale is the normative commitment scale (NCS). As stated in chapter two, normative commitment occurs when employees feel a sense of obligation to their organization and stay because it is the right thing to do. Examples of statements in this scale include: "I do not feel any obligation to remain with my current employer"; "Even if it were to my advantage, I do not feel it would be right to leave my organization right now"; "I owe a great deal to my organization" and "This organization deserves my loyalty". Internal reliability for this scale has ranged from coefficient $\alpha=.73-.89$, with a majority of the studies reporting coefficient $\alpha=.73$ .89 range (Allen et al., 1996; Powell et al., 2004). 
The third scale is the continuance commitment scale (CCS). As discussed in chapter two, continuance commitment is based on the costs associated with leaving an organization. Examples of statements in this scale include: "It would be very hard for me to leave my organization right now, even if I wanted to"; "Too much in my life would be disrupted if I decided I wanted to leave my organization now"; "I feel that I have too few options to consider leaving this organization"; and "If I had not already put so much of myself into this organization, I might consider working elsewhere". Internal reliability for this scale has ranged from coefficient $\alpha=.70-.85$, with a majority of the studies reporting coefficient $\alpha=.79-.85$ range (Allen et al., 1996; Powell et al., 2004).

\section{Organizational Based Self Esteem Survey}

The organizational-based self-esteem survey developed by Pierce et al. in 1989 is the most widely used scale for organizational-based self-esteem. The scale contains 10 items measured on a five point Likert-type disagree-agree scale $(1=$ Strongly Agree; $5=$ Strongly Disagree). Examples of statements included in the scale include: "I am taken seriously"; "I am trusted"; "I am important"; "I can make a difference"; "I am valuable"; and " There is faith in me". Internal reliability for this scale has ranged from coefficient $\alpha=.86-.96$, with a majority of the studies reporting coefficient $\alpha$ of .91 (Pierce et al., 1989; Kanning \& Hill, 2012).

\section{Utrecht Work Engagement Survey}

The Utrecht work engagement survey developed by Schaufeli et al. in 2003 has been extensively used in business, psychology, sociology and healthcare research. The survey is also referred to the "Work and Well-being Survey". The survey 
contains 17 statements that are measured on a seven-point never-always Likert response scale $(0=$ Never; $6=$ Always $)$. The 17 statements cover the three engagement dimensions of vigor ( 6 items), dedication (5 items) and absorption (6 items) outlined in chapter two. Examples of statements included in the scale include: “At my work, I feel bursting with energy"; "Time flies when I'm working”; “At my job, I am very resilient, mentally"; "When I get up in the morning, I feel like going to work"; and "I find the work that I do full of meaning and purpose". Internal reliability for this scale has ranged from coefficient $\alpha=.83-.90$ (Chughtai et al., 2011;

Lawrence, 2011).

Modified Gladstone Survey

The Modified Gladstone Survey, adapted by Osborne et al. (1999) from Gladstone's (1995) questionnaire, has been reliably used to determine nurses' perception of medication errors. The survey consists of 27 items. The first 14 items in the survey address nurses' perception of medication errors; the remaining 13 items are demographic questions that will not be used for this study. Survey responses for this instrument include ranking 10 statements (1-10) as to the frequency of medication errors ("most frequent" = 1 to "least frequent" =10) (1 item); nurse's estimation of percentage of medication errors reported to nurse managers: " $\mathrm{x}$ " marked on a line from $1 \%-100 \%$ ( 1 item); medication error scenarios asking the nurse to identify a possible medication error, and if it warranted reporting to the physician and/or nurse manager (6 items); and "yes/no" questions on views of medication error reporting (6 items). The Modified Gladstone instrument originally had five scenario questions. Mayo and Duncan (2004) added a sixth scenario regarding digoxin levels 
in their study of 983 registered nurses. Ulanimo et al. (2007) used Mayo et al.'s (2004) six-scenario question format in their study of 61 registered nurses. To retain consistency, the digoxin scenario was kept in the instrument for this study. Examples of statements included in the survey include: "Have you ever failed to report a medication error because you were afraid you might be subject to disciplinary action or even lose your job?" and "I am usually sure of what constitutes a medication error". Using the test-retest method, Osborne (1999) established reliability of the modified instrument at $\alpha=$.78. A total score is not calculated for this instrument; therefore survey question number 48 (nurse's estimation of percentage of medication errors reported to nurse managers: " $\mathrm{x}$ " marked on a line from $1 \%$ - 100\%) was used to represent nurse perceptions of medication errors for the structural equation modeling calculations.

\section{Data Analysis}

Data analysis was performed using SPSS and AMOS/mPlus software. SPSS was used to analyze the descriptive statistics (mean, median, mode, standard deviation and percentages) of nurse attributes and facility characteristics. AMOS/mPlus software was used to analyze the proposed conceptual model described in Figure 1 through the use of structural equation modeling (SEM) and confirmatory factor analysis (CFA).

Confirmatory Factor Analysis (CFA)

CFA is a measurement model that is used to study relationships between observed variables (also known as "indicators" indicated by a rectangle shape) and latent variables (also known as "factors" indicated by an oval shape). Many consider 
CFA as first step in the SEM process. Typically theory driven, CFA can assist in the identification of covariation among identified indicators amid a limited amount of factors. This can assist the researcher in building a proposed structural equation model to test hypothesized relationships.

Structural Equation Modeling (SEM)

SEM is a statistical multivariate regression method that allows a researcher to confirm/validate a proposed process or model involving complex relationships between one or more independent and dependent variables through indirect or direct observation (Hoyle, 2012). Many refer to SEM as a cross between an analysis of variance (ANOVA)/regression and a form of factor analysis. Through confirmatory analysis, SEM (1) can assist the researcher in determining if the proposed model is adequate through goodness of fit statistics; (2) can confirm how much variance in the dependent variable(s) is associated with the independent variable(s); and (3) can describe group differences (Hoyle, 2012).

\section{Summary}

Nurses play a vital role in the delivery of care. In an ever changing and complex healthcare environment, the outcomes from this research study aim to facilitate dialogue between organizations and their nursing staff to improve work engagement, and subsequently, improve patient safety and outcomes. 


\section{Chapter 4}

\section{Results}

\section{Introduction}

The main purpose of this study was to test an investigator developed conceptual model to determine if relationships exist between organizational commitment (OC), organizational-based self-esteem (OBSE), nurse work engagement (NWE) and nurses' perception of medication errors from a sample of RNs working in acute care facilities throughout the United States. Specific aims of this study were to describe nurses' perceptions of medication errors, the facilities they work in (facility type; magnet status; size and geographic location), as well as their nursing career attributes (age; education; unit type, hours worked and role; and tenure in organization and profession). Additional aims for this study included evaluating the relationship between nurses' perception of medication errors on nurse attributes and on organizational characteristics.

This chapter begins with a detailed description of the study's participant sample including nurse attributes and facility/organization characteristics. The chapter continues with an in-depth description of the participants' perceptions of medication errors in general, and specific to their personal practice. Next, a description of data cleaning, composite score creation and reliability will be discussed. Finally, a detailed description of the data analysis and results will be presented. 


\section{Description of Participant Sample}

A total of 351 participants took part in this study, with an average age of 38 $(S D=9.87)$ and $38.27(S D=7.51)$ average hours worked per week. The majority of the sample had a BSN degree $(n=236,67.6 \%)$ as their highest degree, had 4 to 6 years $(n=71,20.3 \%)$ of tenure as a nurse, and had been with their organization between 1 and 3 years $(n=92,26.2 \%)$.

Most of the participants worked in either the Medical/Surgical unit ( $n=72$, $20.8 \%)$ or the Neonatal ICU unit $(n=69,19.9 \%)$. The largest role that the participants had was a Bedside/Charge RN $(n=168,48.6 \%)$, while $78.9 \%(n=276)$ did not answer if they had another role in the unit. The majority of participants had stated that they worked in a Magnet designated facility $(n=217,61.8 \%)$, while those who were not in a Magnet designated facility stated that their organization was on the Magnet journey $(n=123,35.0 \%)$. Most of the participants stated that they worked in an urban facility $(n=271,77.2 \%)$ that was almost evenly spread across different states with a slightly higher group from Texas $(n=33,9.4 \%)$.

Between adult and pediatric facilities, $68.7 \%(n=241)$ stated that they worked in an adult facility, while $44.2 \%(n=155)$ stated they worked in a pediatric facility. Most participants stated that their facility was not trauma designated $(n=245,69.8 \%)$ and also stated that they did not work in a teaching facility $(n=179,51.0 \%)$ or a community facility $(n=230,65.5 \%)$. Finally, most participants stated that they worked in a large facility with greater than 500 beds $(n=121,34.5 \%)$. For all frequencies and percentages of descriptive data, see Table 2. For all means and standard deviations for descriptive data, see Table 3. 
Table 2

\begin{tabular}{|c|c|c|}
\hline Demographics & $n$ & $\%$ \\
\hline \multicolumn{3}{|l|}{ Highest Nursing Degree } \\
\hline Diploma & 6 & 1.7 \\
\hline and & 42 & 12.0 \\
\hline BSN & 236 & 67.6 \\
\hline MSN & 62 & 17.8 \\
\hline DNP & 3 & 0.9 \\
\hline \multicolumn{3}{|l|}{ Time with Organization } \\
\hline$<1$ year & 13 & 3.7 \\
\hline $1-3$ years & 92 & 26.2 \\
\hline $4-6$ years & 64 & 18.2 \\
\hline $7-10$ years & 60 & 17.1 \\
\hline $10-15$ years & 53 & 15.1 \\
\hline $15-20$ years & 28 & 8.0 \\
\hline $20-25$ years & 15 & 4.3 \\
\hline $25-30$ years & 13 & 3.7 \\
\hline$>30$ years & 13 & 3.7 \\
\hline \multicolumn{3}{|l|}{ Type of Unit } \\
\hline ICU Adult & 49 & 14.2 \\
\hline ICU Pediatric & 13 & 3.8 \\
\hline ICU Neonatal & 69 & 19.9 \\
\hline Medical & 22 & 6.4 \\
\hline Surgical & 16 & 4.6 \\
\hline Medical/Surgical & 72 & 20.8 \\
\hline Rehabilitation & 10 & 2.9 \\
\hline OR & 16 & 4.6 \\
\hline PACU & 13 & 3.8 \\
\hline Hem/Onc & 9 & 2.6 \\
\hline Transplant & 1 & 0.3 \\
\hline LD & 15 & 4.3 \\
\hline ED & 23 & 6.5 \\
\hline Peds & 7 & 2.0 \\
\hline Psych Peds & 3 & 0.9 \\
\hline Resource Pool & 4 & 1.2 \\
\hline Stepdown & 4 & 1.2 \\
\hline \multicolumn{3}{|l|}{ Role in Unit } \\
\hline Bedside RN & 140 & 40.4 \\
\hline Bedside/Charge RN & 168 & 48.6 \\
\hline Resource RN & 9 & 2.6 \\
\hline Educator/CNS & 29 & 8.4 \\
\hline \multicolumn{3}{|l|}{ Other Role in Unit } \\
\hline Clinical Supervisor 50\% & 1 & 0.3 \\
\hline Educator & 3 & 0.9 \\
\hline Educator CNS & 1 & 0.3 \\
\hline Educator RN & 1 & 0.3 \\
\hline Educator/CNS & 1 & 0.3 \\
\hline Lead & 1 & 0.3 \\
\hline Neo Response RN & 1 & 0.3 \\
\hline PPS Coordinator & 1 & 0.3 \\
\hline
\end{tabular}




\begin{tabular}{|c|c|c|}
\hline Rapid Response RN & 1 & 0.3 \\
\hline Relief Charge & 1 & 0.3 \\
\hline Resource RN & 23 & 6.6 \\
\hline Scheduling & 1 & 0.3 \\
\hline Specialty/Head RN & 1 & 0.3 \\
\hline Stabilizing RN & 1 & 0.3 \\
\hline Transport RN & 1 & 0.3 \\
\hline Wound Ostomy Consultant & 1 & 0.3 \\
\hline Did not answer & 311 & 88.3 \\
\hline \multicolumn{3}{|l|}{ Tenure as RN } \\
\hline$<1$ year & 6 & 1.7 \\
\hline $1-3$ years & 61 & 17.4 \\
\hline $4-6$ years & 71 & 20.3 \\
\hline $7-10$ years & 52 & 14.9 \\
\hline $10-15$ years & 33 & 9.4 \\
\hline $15-20$ years & 48 & 13.7 \\
\hline $20-25$ years & 29 & 8.3 \\
\hline $25-30$ years & 24 & 6.9 \\
\hline$>30$ years & 26 & 7.4 \\
\hline \multicolumn{3}{|l|}{ Magnet Designated Facility } \\
\hline Yes & 217 & 61.8 \\
\hline No & 130 & 37.0 \\
\hline Did not answer & 3 & 1.2 \\
\hline \multicolumn{3}{|l|}{ On Magnet Journey } \\
\hline Yes & 123 & 35.0 \\
\hline No & 11 & 3.1 \\
\hline Did not answer & 217 & 61.9 \\
\hline \multicolumn{3}{|l|}{ Location of Facility } \\
\hline Rural & 70 & 19.9 \\
\hline Urban & 271 & 77.3 \\
\hline Did not answer & 10 & 2.8 \\
\hline \multicolumn{3}{|l|}{ State } \\
\hline AZ & 5 & 1.4 \\
\hline $\mathrm{CA}$ & 24 & 6.8 \\
\hline $\mathrm{CO}$ & 6 & 1.7 \\
\hline $\mathrm{CT}$ & 3 & 0.9 \\
\hline $\mathrm{DC}$ & 3 & 0.9 \\
\hline DE & 2 & 0.6 \\
\hline $\mathrm{FL}$ & 22 & 6.3 \\
\hline GA & 17 & 4.8 \\
\hline IA & 3 & 0.9 \\
\hline ID & 1 & 0.3 \\
\hline IL & 10 & 2.8 \\
\hline IN & 10 & 2.8 \\
\hline $\mathrm{KS}$ & 2 & 0.6 \\
\hline KY & 6 & 1.7 \\
\hline MA & 1 & 0.3 \\
\hline MD & 6 & 1.7 \\
\hline MI & 1 & 0.3 \\
\hline $\mathrm{MN}$ & 2 & 0.6 \\
\hline MO & 1 & 0.3 \\
\hline
\end{tabular}




\begin{tabular}{|c|c|c|}
\hline MT & 1 & 0.3 \\
\hline $\mathrm{NC}$ & 9 & 2.6 \\
\hline ND & 1 & 0.3 \\
\hline $\mathrm{NE}$ & 1 & 0.3 \\
\hline $\mathrm{NH}$ & 5 & 1.4 \\
\hline NJ & 2 & 0.6 \\
\hline NY & 13 & 3.7 \\
\hline $\mathrm{OH}$ & 13 & 3.7 \\
\hline OK & 1 & 0.3 \\
\hline OR & 7 & 2.0 \\
\hline PA & 17 & 4.8 \\
\hline RI & 2 & 0.6 \\
\hline $\mathrm{SC}$ & 4 & 1.1 \\
\hline SD & 3 & 0.9 \\
\hline $\mathrm{TN}$ & 9 & 2.6 \\
\hline $\mathrm{TX}$ & 33 & 9.4 \\
\hline VA & 3 & 0.9 \\
\hline WA & 1 & 0.3 \\
\hline WI & 6 & 1.7 \\
\hline WV & 1 & 0.3 \\
\hline Did not answer & 94 & 26.8 \\
\hline \multicolumn{3}{|l|}{ Adult Facility } \\
\hline Yes & 241 & 68.7 \\
\hline No & 108 & 30.8 \\
\hline Did not answer & 4 & 0.5 \\
\hline \multicolumn{3}{|l|}{ Pediatric Facility } \\
\hline Yes & 155 & 44.2 \\
\hline No & 195 & 55.5 \\
\hline Did not answer & 1 & 0.3 \\
\hline \multicolumn{3}{|l|}{ Trauma Facility } \\
\hline Yes & 105 & 29.9 \\
\hline No & 245 & 69.8 \\
\hline Did not answer & 1 & 0.3 \\
\hline \multicolumn{3}{|l|}{ Teaching Facility } \\
\hline Yes & 171 & 48.7 \\
\hline No & 179 & 51.0 \\
\hline Did not answer & 1 & 0.3 \\
\hline \multicolumn{3}{|c|}{ Community Facility } \\
\hline Yes & 119 & 33.9 \\
\hline No & 230 & 65.5 \\
\hline Did not answer & 2 & 0.6 \\
\hline \multicolumn{3}{|c|}{ Size of Facility (Beds) } \\
\hline$<200$ & 40 & 11.4 \\
\hline $200-300$ & 77 & 21.9 \\
\hline $301-400$ & 67 & 19.1 \\
\hline $401-500$ & 45 & 12.8 \\
\hline$>500$ & 121 & 34.5 \\
\hline Did not answer & 1 & 0.3 \\
\hline
\end{tabular}

Table 2. Frequencies and Percentages for Demographic Information 
Table 3

\begin{tabular}{lcccc}
\hline & Min. & Max. & $M$ & $S D$ \\
\hline Age & 22 & 62 & 37.60 & 9.87 \\
Hours/Per & 6 & 72 & 38.27 & 7.51 \\
Week & & & & \\
\hline
\end{tabular}

Table 3. Means and Standard Deviations for Demographic Variables

\section{Nurses' Perception of Medication Errors}

\section{Causes of Medication Errors}

Using the Modified Gladstone instrument, nurses' perception of medication errors was recorded and evaluated. Participants were near even when they thought drug errors occurred when the nurse failed to check the patients' name with that on the Medication Administration Record (MAR), with $15.7 \%(n=55,15.7 \%)$ participants believing this was a frequent cause and $13.1 \%(n=46,13.1 \%)$ participants believing this was an infrequent cause. Close to half of the participants believed that illegible physician handwriting was not a frequent cause ( $n=143$, $40.7 \%$ ) of medication errors. This may be due to the implementation of computerized physician order entry (CPOE) in most hospitals over the last decade. Poor medication labels were also considered to be an infrequent cause $(n=73,20.8 \%)$ of medication errors. Confusion between drugs, physician prescribing the wrong dose, nurses miscalculating dose, using the wrong infusion device, and using infusion devices incorrectly were all rated in the middle of being frequent and infrequent causes of medication errors. There was no strong belief among participants that these variables either played a strong or weak role in medication errors. However, being distracted by others was rated as a frequent cause $(n=113,33.3 \%)$ of medication errors, as was 
exhaustion $(n=88,25.1 \%)$. All frequencies and percentages for the variables affecting medication errors are presented in Table 4.

Table 4

\begin{tabular}{|c|c|c|}
\hline Modified Gladstone - Causes of Med Errors Ranking & $n$ & $\%$ \\
\hline \multicolumn{3}{|l|}{ Failed to check MAR } \\
\hline Most Frequent & 55 & 15.7 \\
\hline 2 & 33 & 9.4 \\
\hline 3 & 43 & 12.3 \\
\hline 4 & 28 & 8.0 \\
\hline 5 & 25 & 7.1 \\
\hline 6 & 33 & 9.4 \\
\hline 7 & 25 & 7.1 \\
\hline 8 & 27 & 7.7 \\
\hline 9 & 31 & 8.8 \\
\hline Least Frequent & 46 & 13.1 \\
\hline No Answer & 5 & 1.4 \\
\hline \multicolumn{3}{|l|}{ Illegible Physician Writing } \\
\hline Most Frequent & 22 & 6.3 \\
\hline 2 & 20 & 5.7 \\
\hline 3 & 27 & 7.7 \\
\hline 4 & 15 & 4.3 \\
\hline 5 & 21 & 6.0 \\
\hline 6 & 18 & 5.1 \\
\hline 7 & 16 & 4.6 \\
\hline 8 & 25 & 7.1 \\
\hline 9 & 38 & 10.8 \\
\hline Least Frequent & 143 & 40.7 \\
\hline No Answer & 6 & 1.7 \\
\hline \multicolumn{3}{|l|}{ Poor Medication Labels } \\
\hline Most Frequent & 16 & 4.5 \\
\hline 2 & 14 & 4.0 \\
\hline 3 & 25 & 7.1 \\
\hline 4 & 29 & 8.3 \\
\hline 5 & 30 & 8.5 \\
\hline 6 & 36 & 10.3 \\
\hline 7 & 42 & 12.0 \\
\hline 8 & 43 & 12.2 \\
\hline 9 & 73 & 20.8 \\
\hline Least Frequent & 36 & 10.3 \\
\hline No Answer & 7 & 2.0 \\
\hline \multicolumn{3}{|l|}{ Confusion Between Drugs } \\
\hline Most Frequent & 16 & 4.6 \\
\hline 2 & 23 & 6.6 \\
\hline 3 & 33 & 9.4 \\
\hline 4 & 46 & 13.1 \\
\hline 5 & 44 & 12.5 \\
\hline 6 & 38 & 10.8 \\
\hline
\end{tabular}




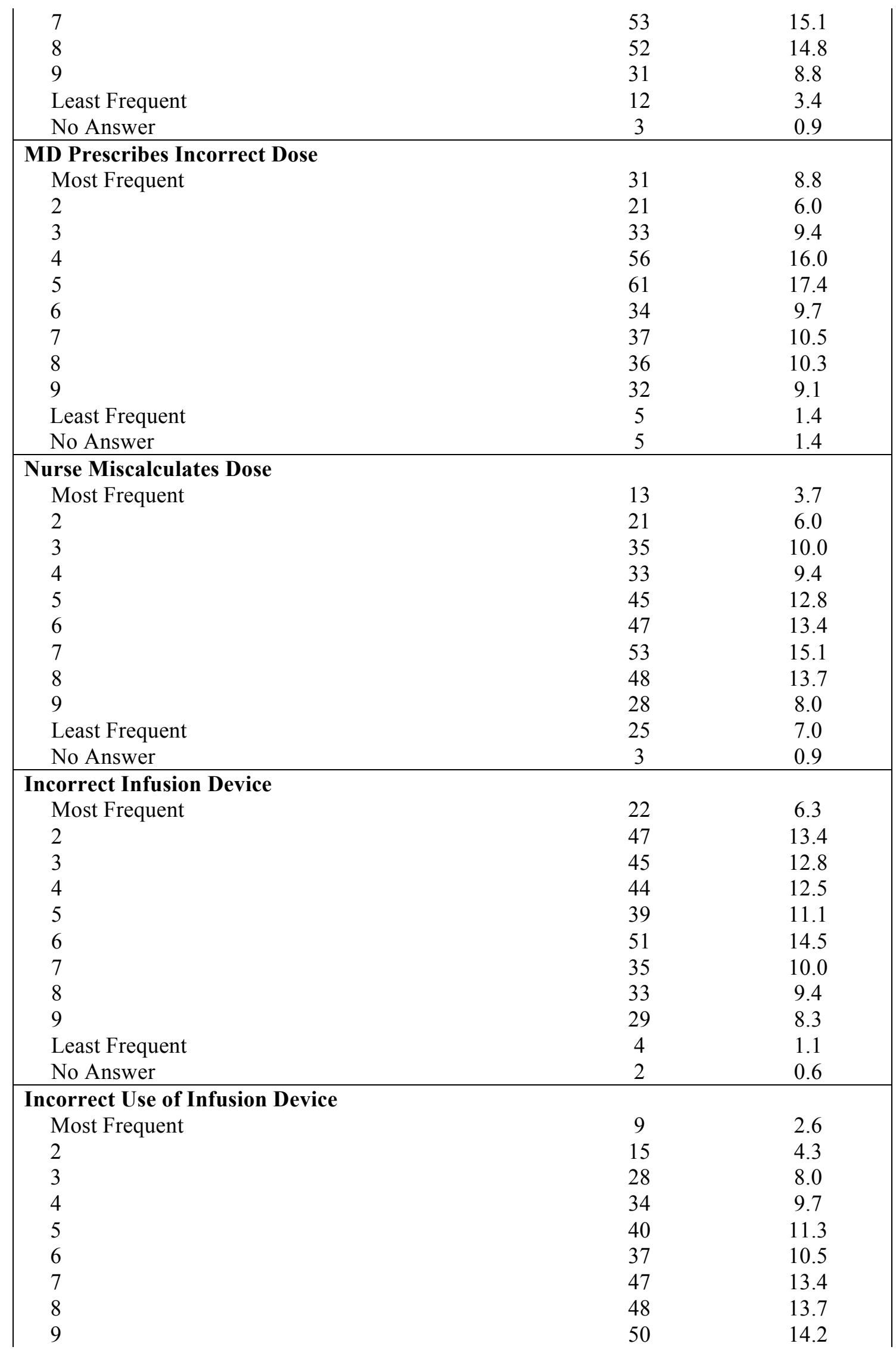




\begin{tabular}{|lcc|} 
Least Frequent & 41 & 11.7 \\
No Answer & 2 & 0.6 \\
\hline Distracted by Others & & \\
Most Frequent & 117 & 33.3 \\
2 & 70 & 19.9 \\
3 & 38 & 10.8 \\
4 & 24 & 6.8 \\
5 & 21 & 6.0 \\
6 & 20 & 5.7 \\
7 & 18 & 5.3 \\
8 & 12 & 3.4 \\
9 & 13 & 3.7 \\
Least Frequent & 17 & 4.8 \\
No Answer & 1 & 0.3 \\
\hline Exhaustion & & \\
Most Frequent & 88 & 25.1 \\
2 & 84 & 23.9 \\
3 & 38 & 10.8 \\
4 & 36 & 10.3 \\
5 & 23 & 6.6 \\
6 & 25 & 7.1 \\
7 & 14 & 4.0 \\
8 & 11 & 3.1 \\
9 & 14 & 4.0 \\
Least Frequent & 17 & 4.8 \\
No Answer & 1 & 0.3 \\
\hline Table 4.Frequences & \\
\hline
\end{tabular}

Table 4. Frequencies and Percentages of Possible Medication Error Causes

Drug Error Scenarios

In addition to ranking the causes of medication errors, participants were asked to read six scenarios in which a drug discrepancy occurred. After reading each scenario, participants were presented with three questions: (1) Did a medication error occur, (2) Should the physician be notified, and (3) Should an incident report be completed.

In the first scenario, a patient misses a dose of antibiotic due to an extended stay in the radiology department. Over half ( $n=206,58.7 \%)$ of participants stated that the missed dose was not a drug error, but the majority $(n=279,79.5 \%)$ said that 
the doctor should be notified, and just over half stated $(n=210,59.8 \%)$ said that an incident report would not need to be filed.

In the second scenario, four patients receive their dose of antibiotics four hours late. The majority of participants $(n=243,69.2 \%)$ in this scenario stated that this was a drug error, $84.0 \%(n=295)$ stated they would notify a doctor, and $71.8 \%$ $(n=252)$ said they would file an incident report.

In the third scenario, a patient receives an infusion at an incorrect rate for the first three hours of a 24-hour infusion. In this scenario, a majority of participants $(n=$ $336,95.7 \%)$ said that this was a drug error, that the doctor would be notified $(n=316$, 90.0\%), and that an incident report would be filed $(n=338,96.3 \%)$.

In the fourth scenario, a nurse omits a 6am nebulizer for an asthmatic patient because he/she is asleep. Just over half $(n=188,53.6 \%)$ of the participants for this scenario believed this constituted a drug error, $73.4 \%(n=254)$ said that they would notify the doctor, and 53.8\% $(n=189)$ said they would file an incident report.

The fifth scenario, a patient is ordered 1-2 tabs of pain medication every four hours. At 4pm, the patient received one tab for pain. Two and one-half hours later $(6: 30 \mathrm{pm})$, he requests and is administered another tab for pain. The majority of participants $(n=221,63.0 \%)$ in this scenario said that this was not a drug error, $61.0 \%(n=214)$, said that they would not notify a doctor, and $65.2 \%(n=229)$ said they would not file an incident report.

In the final scenario, a patient's cardiac medication is held due to a delayed lab results. The patient's lab results the previous day was on the high side of normal. A majority of participants $-81.2 \%(n=285)$ said that this was not a drug error, $61.0 \%$ 
$(n=214)$ said they would notify a doctor, and 76.6\% $(n=269)$ said they would not file an incident report. All frequencies and percentages for the medication error scenarios are presented in Table 5.

Table 5

\begin{tabular}{|c|c|c|}
\hline Perception of Medication Errors -- Scenarios & $n$ & $\%$ \\
\hline \multicolumn{3}{|l|}{ Scenario 1 - Missed Dose (Drug Error) } \\
\hline Yes & 134 & 38.2 \\
\hline No & 206 & 58.7 \\
\hline No Answer & 11 & 3.1 \\
\hline \multicolumn{3}{|l|}{ Scenario 1 - Missed Dose (Notify MD) } \\
\hline Yes & 279 & 79.5 \\
\hline No & 65 & 18.5 \\
\hline No Answer & 7 & 2.0 \\
\hline \multicolumn{3}{|l|}{ Scenario 1 - Missed Dose (Incident Report) } \\
\hline Yes & 131 & 37.4 \\
\hline No & 210 & 59.8 \\
\hline No Answer & 10 & 2.8 \\
\hline \multicolumn{3}{|l|}{ Scenario 2 - Late Dose (Drug Error) } \\
\hline Yes & 243 & 69.2 \\
\hline No & 96 & 27.4 \\
\hline No Answer & 12 & 3.4 \\
\hline \multicolumn{3}{|l|}{ Scenario 2 - Late Dose (Notify MD) } \\
\hline Yes & 295 & 84.0 \\
\hline No & 49 & 14.0 \\
\hline No Answer & 7 & 2.0 \\
\hline \multicolumn{3}{|l|}{ Scenario 2 - Late Dose (Incident Report) } \\
\hline Yes & 252 & 71.8 \\
\hline No & 88 & 25.1 \\
\hline No Answer & 11 & 3.1 \\
\hline \multicolumn{3}{|l|}{ Scenario 3- Incorrect Pump Rate (Drug Error) } \\
\hline Yes & 336 & 95.8 \\
\hline No & 11 & 3.1 \\
\hline No Answer & 4 & 1.1 \\
\hline \multicolumn{3}{|l|}{ Scenario 3 - Incorrect Pump Rate (Notify MD) } \\
\hline Yes & 316 & 90.0 \\
\hline No & 29 & 8.3 \\
\hline No Answer & 6 & 1.7 \\
\hline \multicolumn{3}{|c|}{ Scenario 3 - Incorrect Pump Rate (Incident Report) } \\
\hline Yes & 338 & 96.3 \\
\hline No & 9 & 2.6 \\
\hline No Answer & 4 & 1.1 \\
\hline \multicolumn{3}{|l|}{ Scenario 4-Omitted Dose (Drug Error) } \\
\hline Yes & 188 & 53.6 \\
\hline No & 151 & 43.0 \\
\hline No Answer & 12 & 3.4 \\
\hline
\end{tabular}




\begin{tabular}{|lcc|} 
Scenario 4 - Omitted Dose (Notify MD) & & \\
Yes & 254 & 72.3 \\
No & 91 & 26.0 \\
No Answer & 6 & 1.7 \\
Scenario 4 - Omitted Dose (Incident Report) & & \\
Yes & 189 & 53.8 \\
No & 153 & 43.6 \\
No Answer & 9 & 2.6 \\
\hline Scenario 5 - Dose Administration (Drug Error) & & \\
Yes & 122 & 34.7 \\
No & 221 & 63.0 \\
No Answer & 8 & 2.3 \\
Scenario 5 - Dose Administration (Notify MD) & & \\
Yes & 133 & 37.9 \\
No & 214 & 61.0 \\
No Answer & 4 & 1.1 \\
Scenario 5 - Dose Administration (Incident Report) & & \\
Yes & 111 & 31.6 \\
No & 229 & 65.3 \\
No Answer & 11 & 3.1 \\
\hline Scenario 6 - Dose Delay (Drug Error) & & \\
Yes & 55 & 15.7 \\
No & 285 & 81.2 \\
No Answer & 11 & 3.1 \\
Scenario 6 - Dose Delay (Notify MD) & & \\
Yes & 214 & 61.0 \\
No & 135 & 38.4 \\
No Answer & 2 & 0.6 \\
Scenario 6 - Dose Delay (Incident Report) & 73 & 20.8 \\
Yes & 269 & 2.6 \\
No & 9 & \\
No Answer & & \\
\hline
\end{tabular}

Table 5. Frequencies and Percentages for Medication Error Scenarios

Nurses' Views on Reporting Errors

In the final section of the Modified Gladstone instrument, participants were asked about their personal views on reporting medication errors. The majority $(n=$ $310,88.3 \%$ ) of participants said that they did know what constitutes a medication error, $88.6 \%(n=311)$ of participants stated that they know when to file an incident report, $74.9 \%(n=263)$ said that medication errors are not reported because of fear of the reaction of their Nurse Manager, and $69.5 \%(n=244)$ failed reporting of 
medication errors occurred because of fear of their peer's reactions. When asked if the participants themselves failed to report a medication error because they did not think it was serious, the responses were close to even with $42.7 \%(n=150)$ stating that they did not report the error and $57.0 \%(n=200)$ stating that they did report the error. When asked if a medication error was not reported out of fear for disciplinary action or loss of a job, the majority of participants $(n=280,79.8 \%)$ said they had not ever failed to report a medication error out of personal fear. Table 6 provides frequencies and percentages for the participants' personal views on reporting medication errors.

Table 6

\begin{tabular}{lcc}
\hline Personal views on Reporting Medication Errors & $n$ & $\%$ \\
\hline What Constitutes Drug Error & 310 & 88.3 \\
Yes & 39 & 11.1 \\
No & 2 & 0.6 \\
No Answer & 311 & 88.6 \\
When to File Incident Report & 40 & 11.4 \\
Yes & 0 & 0.0 \\
No & & \\
No Answer & 263 & 74.9 \\
Fear of Reported Error (Manager) & 86 & 24.5 \\
Yes & 2 & 0.6 \\
No & & \\
No Answer & 244 & 69.5 \\
Fear of Reported Error (Peers) & 107 & 30.5 \\
Yes & 0 & 0.0 \\
No & & \\
No Answer & 150 & 42.7 \\
Fail to Report Due to Lack of Drug Error Severity & 200 & 57.0 \\
Yes & 1 & 0.3 \\
No & & \\
No Answer & 71 & 20.2 \\
Fear of Reported Error (Self) & 280 & 79.8 \\
Yes & 0 & 0.0 \\
No & $072 p o r$ \\
No Answer & & \\
\hline Table 6. Frequencies and Percentages for Persons
\end{tabular}

Table 6. Frequencies and Percentages for Personal Views on Reporting Med Errors 


\section{Data Cleaning}

A total of 19 variables (see Table 1) were tested using four instruments - the

Three-Component Model of Employee Commitment Survey, the Organizational Based Self Esteem Survey, the Utrecht Work Engagement Survey, and the Modified Gladstone Survey. All instruments except for the demographic questionnaire and Modified Gladstone were measured on a five-point Likert scale. Four items on the Three-Component Model of Employee Commitment Survey were reverse scored and reverse coded in SPSS. Items for Affective Commitment questions 3, 4, and 5 and Normative Commitment question 1 were recoded, where 1 = "Strongly Disagree", 2 = "Disagree", 3 = "Undecided", 4 = "Agree", 5 = "Strongly Agree". Once complete, composite scores were created by computing the mean for Affective Commitment (AC), Continuous Commitment (CC), Normative Commitment (NC), Vigor, Dedication, Absorption, and Organizational Based Self-Esteem (OBSE). These composite scores were used in the final analyses in this study.

\section{Cronbach's Alpha}

Internal reliability (consistency) is an important measure that quantifies if an instrument's items all measure the intended concept consistently (Tavakol \& Dennick, 2011). For the purpose of this study, the Chronbach alpha is used, with a range of 0 to 1 . Cronbach's alpha values were calculated for the each of the composite scores created. The coefficients were evaluated using guidelines set forth by George and Mallery (2010), where values greater than .90 indicate excellent reliability, values greater than .70 indicate acceptable reliability, and values less than .50 indicate unacceptable reliability. All of the composite scores in the study had 
standard acceptable inter rater reliability with $\alpha=0.62$ to 0.97 . For all of the Cronbach's alpha scores, see Table 7.

Table 7

\begin{tabular}{lrr}
\hline Construct & Standardized $\alpha$ & No. of Items \\
\hline AC & 0.76 & 6 \\
CC & 0.62 & 6 \\
NC & 0.74 & 6 \\
OBSE & 0.97 & 10 \\
Vigor & 0.80 & 6 \\
Dedication & 0.82 & 5 \\
Absorption & 0.76 & 6
\end{tabular}

Table 7. Cronbach's Alpha Reliability for Composite Scores

\section{Detailed Results}

The main purpose of this study was to test an investigator developed conceptual model to determine if relationships exist between organizational commitment (OC), organizational-based self-esteem (OBSE), nurse work engagement (NWE) and nurses' perception of medication errors from a sample of RNs working in acute care facilities throughout the United States (see Figure 1). 


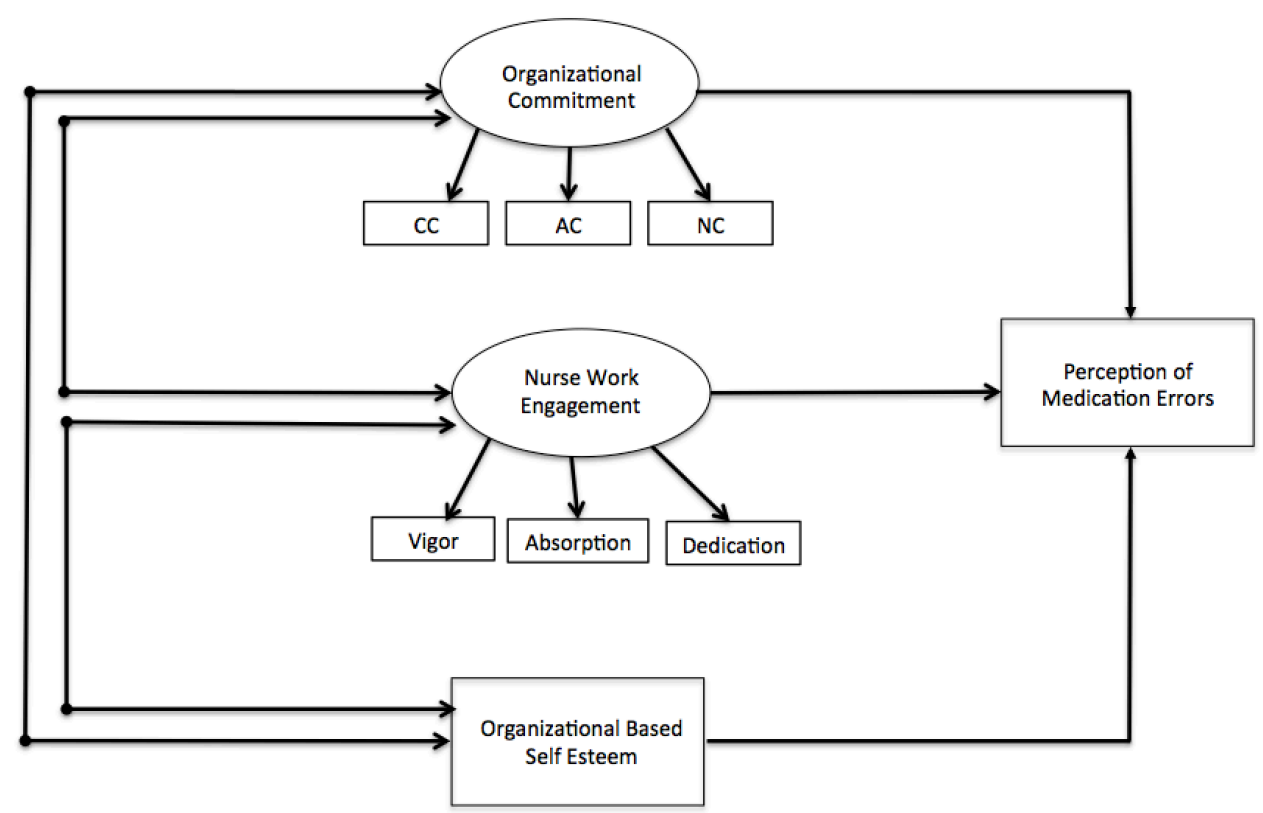

Figure 1 - Proposed Structural Equation Model

\section{Confirmatory Factor Analysis}

A confirmatory factor analysis (CFA) was conducted in order to see if the observed and latent variables for the overall model would be a good fit. The composite scores for $\mathrm{AC}, \mathrm{CC}, \mathrm{NC}$ were all entered under one latent variable (Organizational Commitment). The composite scores for Vigor, Dedication, and Absorption were entered under the latent variable for NWE. Finally, the composite score for OBSE was entered on its own and covaried with OC and NWE. The final variable entered was for perceptions of medication errors, which was only made up of one observed variable.

The initial results of the CFA did not show good model fit $\left(\chi^{2}(19)=119.02, p\right.$ $<.001, C F I=.87, T L I=.81, R M S E A=.12)$. A significant $p$-value for the Chi-square test indicates that the observed covariance matrix is significantly different from the implied model covariance matrix (Ong \& Van Dulmen, 2007). In order to improve 
model fit, modification indices were examined to determine which parameter constraints were significantly limiting the model fit of the observed covariance structure. Modification indices are indicators of how the model could be improved (McCoach, Gable \& Madura, 2013). The modification indices showed that the error terms of the observed variables for OC and NWE could covary. The results of the CFA with the covariations showed much improved fit, $\left(\chi^{2}(12)=30.84, p=.002, C F I\right.$ $=.98, T L I=.94$, RMSEA $=.07)$. A good model fit is defined as having CFI and TLI values greater than .9 and an RMSEA value less than .06 (Hu \& Bentler, 1999). The Chi-square test showed that the model did not fit the data, but the Chi-square test is based upon sample size. The larger the sample size, the more likely the Chi-square test will be significant (Ong \& Van Dulmen, 2007). However, one of the assumptions of CFA and SEM is that you have a large enough sample size, so it is more likely that the Chi-square test will be significant. The fit statistics show that the CFA is reasonably specified, even though the RMSEA is a little high. A summary of the model iterations is given in Table 8 .

Table 8

\begin{tabular}{lrrrrrr}
\hline CFA & $\chi^{2}$ & $d f$ & $p$ & $C F I$ & $T L I$ & RMSEA \\
\hline No MI & 119.02 & 19 & $<.001$ & .87 & .81 & .12 \\
MI & 30.84 & 12 & .002 & .98 & .94 & .07 \\
\hline
\end{tabular}

Note. MI $=$ Modification Indices

Table 8. Confirmatory Factor Analysis Fit Indices

\section{Structural Equation Model}

In order to examine the second aim of this study, a structural equation model (SEM) was created based on the variables used in the CFA. The model was created with the same observed variables used for the latent variable of OC. The same three 
observed variables for NWE were also used. The composite score for OBSE was again entered. Finally, the dependent variable (Perception of Medication Errors) was regressed onto the three independent variables. The proposed model is depicted in

\section{Figure 1.}

\section{Model Specification}

The initial results of the model did not show good model fit $\left(\chi^{2}(16)=101.79\right.$, $p<.001, C F I=.89, T L I=.81, R M S E A=.12)$. A significant $p$-value for the Chisquare test indicates that the observed covariance matrix is significantly different from the implied model covariance matrix. In order to improve model fit, modification indices were examined to determine which parameter constraints were significantly limiting the model fit of the observed covariance structure. The modification indices showed that the error terms could be covaried. The results of the model with the covariations showed much improved fit, $\left(\chi^{2}(10)=25.09, p=.005\right.$, $C F I=.98, T L I=.95, R M S E A=.07)$. With the covariation of the error terms, the fit was improved. The same standards for the CFA fit values apply to the SEM fit values. A good model fit is defined as having CFI and TLI values greater than .9 and an RMSEA value less than .06 (Hu et al., 1999).

The Chi-square test showed that the model did not fit the data, but the Chisquare test is based upon sample size. The larger the sample size, the more likely the Chi-square test will be significant (Ong et al., 2007). However, one of the assumptions of CFA and SEM is that you have a large enough sample size, so it is more likely that the Chi-square test will be significant. The fit statistics show that the 
model is reasonably specified, even though the RMSEA is slightly higher than the standard cutoff value. A summary of the model iterations is given in Table 9.

Table 9

\begin{tabular}{lrrrrrr}
\hline SEM & $\chi^{2}$ & $d f$ & $p$ & CFI & TLI & RMSEA \\
\hline No MI & 101.79 & 16 & $<.001$ & .89 & .81 & .12 \\
MI & 25.09 & 10 & .005 & .98 & .95 & .07
\end{tabular}

Note. MI = Modification Indices

Table 9. Structural Equation Model Fit Indices

\section{Composite Reliability}

Composite reliability is measured in the same manner as Cronbach's alpha.

Values are measured between 0 and 1 , with higher values signifying higher reliability.

Values between .70 and .90 are considered satisfactory (Hair Jr., Hult, Ringle, \& Sarstedt, 2013). Composite reliability was assessed to determine how well each indicator loaded onto their respective constructs. This is done by taking a ratio of square of summed loadings and the total variance. See equation below (Raykov, 1997):

$$
C R=\frac{\left(\sum \lambda_{i}\right)^{2}}{\left(\sum \lambda_{i}\right)^{2}+\sum \operatorname{Var}\left(\varepsilon_{i}\right)}
$$

In the model there were only two latent constructs (OC and NWE).

Organizational Commitment had acceptable composite reliability $(\mathrm{CR}=0.79)$. Nurse Work Engagement had great composite reliability $(C R=0.92)$, suggesting that both constructs were reliable measures. The composite reliability values for each construct are given in Table 10. 
Table 10

\begin{tabular}{lcc}
\hline Model & OC & NWE \\
\hline $\begin{array}{l}\text { Structural } \\
\text { Equation Model }\end{array}$ & 0.79 & 0.92 \\
\hline Table 10. Composite Relability for Each Construt
\end{tabular}

Table 10. Composite Reliability for Each Construct

\section{Factor Correlations}

After respecifying the model until acceptable fit was achieved, the correlation and regression estimates were examined. The factor correlations were calculated between the two latent and the one observed independent variables. The OC and NWE variables had a correlation coefficient of -0.43 , indicating a medium negative relationship. The OC latent variable also was positively correlated with OBSE ( $r=$ 0.13), indicating a weak positive relationship. The NWE variable was negatively correlated with OBSE $(r=-0.13)$. The latent variable correlation matrix is shown in

\section{Table 11.}

Table 11

\begin{tabular}{lccc}
\hline Construct & OC & NWE & OBSE \\
\hline OC & - & & \\
NWE & -0.43 & - & \\
OBSE & 0.13 & -0.13 & - \\
\hline
\end{tabular}

Table 11. Factor Correlations for Independent Measures

\section{Regression Estimates}

Standardized regression paths were included in the model between each of the independent and dependent latent and observed variables, as well as $\mathrm{AC}, \mathrm{CC}, \mathrm{NC}$, Vigor, Dedication, and Absorption. The standardized regression path for perception of medication errors regressed on OC showed no significance $(B=-0.06, p=.414)$. This indicates that there is no relationship between OC and perception of medication errors. The standardized regression path for perception of medication errors regressed 
on NWE also showed no significance $(B=0.12, p=.065)$. This indicates that there is also no relationship between NWE and perception of medication errors. For perception of medication errors regressed on OBSE, there was a significant result ( $B$ $=-0.14, p=.010)$. This indicates that OBSE had a negative effect on perception of medication errors. For OC regressed on $\mathrm{AC}, \mathrm{NC}$, and $\mathrm{CC}$, the paths showed significance. The standardized regression path for AC was $0.77(p<.001)$. For NC, the standardized path was $0.75(p<.001)$. For CC, the standardized path was 0.30 ( $p$ $<.001)$. This indicates that there is a positive relationship between $\mathrm{OC}, \mathrm{AC}, \mathrm{NC}$, and CC. For NWE regressed on Vigor, Dedication, and Absorption, the paths showed significance. The standardized regression path for Absorption was $0.76(p<.001)$. For Dedication, the standardized regression path was $0.78(p<.001)$. For Vigor, the standardized path was $0.91(p<.001)$. This indicates that there was a positive relationship between NWE, Absorption, Vigor, and Dedication. A summary of the regression results is outlined in Table 12. A path diagram with the results of the model is shown in Figure 2.

\begin{tabular}{|c|c|c|c|c|}
\hline Regression & $B$ & $S E$ & $z$ & $p$ \\
\hline $\mathrm{PME} \sim \mathrm{OC}$ & -0.55 & 3.36 & -0.82 & .417 \\
\hline PME NWE & 0.12 & 2.53 & 1.85 & .064 \\
\hline PME OBSE & -0.14 & 1.68 & -2.57 & $.010^{*}$ \\
\hline \multicolumn{5}{|l|}{ OC } \\
\hline $\mathrm{NC}$ & 0.75 & 0.17 & 6.10 & $<.001^{*}$ \\
\hline CC & 0.30 & 0.10 & 3.68 & $<.001^{*}$ \\
\hline $\mathrm{AC}$ & 0.77 & 0.16 & 6.10 & $<.001^{*}$ \\
\hline \multicolumn{5}{|l|}{ NWE } \\
\hline Dedication & 0.78 & 0.05 & 15.67 & $<.001^{*}$ \\
\hline Absorption & 0.76 & 0.06 & 14.71 & $<.001^{*}$ \\
\hline Vigor & 0.91 & 0.08 & 15.67 & $<.001^{*}$ \\
\hline
\end{tabular}

Note. * Indicates a significant relationship. PME $=$ Perception of Medication Error, OC $=$ Organizational Commitment, $\mathrm{NWE}=$ Nurse Work Engagement, $\mathrm{NC}=$ Normative Commitment, $\mathrm{CC}=$ Continuous Commitment, $\mathrm{AC}=$ Affective Commitment.

Table 12. Standardized Regression Paths 


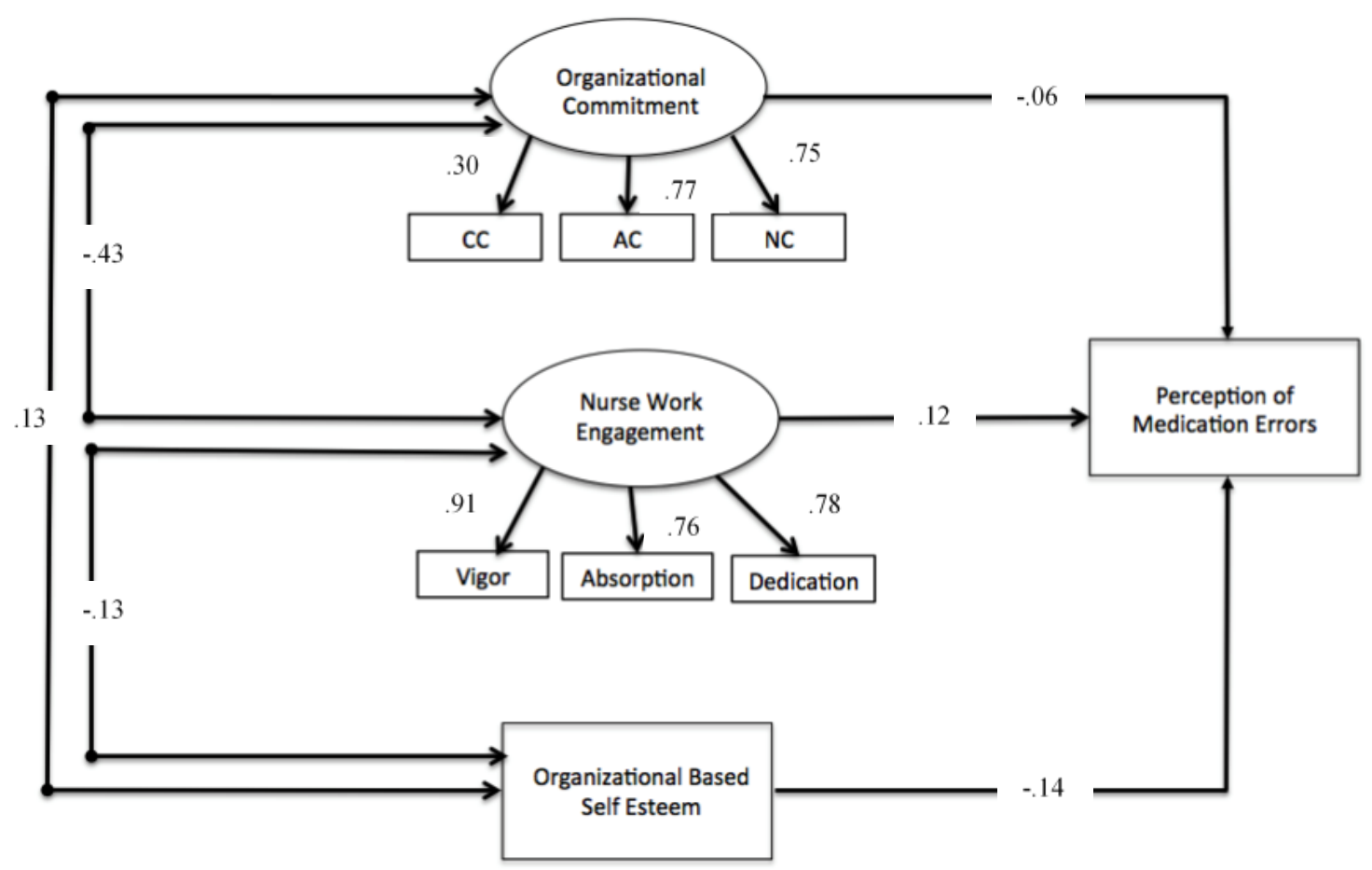

Figure 2. Structural Equation Model with Regression Weights

\section{Multiple Regression}

In order to assess aims three and four of this study, a multiple regression was used to test the relationship of organizational characteristics (facility type; magnet status, size, and geographic location) and nurse attributes (age, education, unit type, hours worked, role, and tenure in organization and profession) on perception of medication errors. After adding all of the variables for organizational characteristics and nurse attributes, the results for the overall model were not statistically significant, $F(17,286)=0.57, p=.910, R^{2}=0.18$. This suggests that there is no relationship between organizational characteristics, nurse attributes, and perception of medication errors. The independent variables accounted for only $18 \%\left(R^{2}\right)$ of the variance in 
perception of medication errors. The results of the regression are presented in Table 13.

Table 13

\begin{tabular}{lcccccc}
\hline \multicolumn{1}{c}{ Model } & $B$ & $S E$ & $\beta$ & $t$ & $P$ & $95 \%$ CI \\
\hline Age & 0.09 & 0.28 & 0.03 & 0.31 & .758 & {$[-0.47,0.64]$} \\
Nursing & -0.28 & 2.35 & -0.01 & -0.12 & .905 & {$[-4.91,4.35]$} \\
Degree & & & & & & \\
Hours/Week & -0.11 & 0.21 & -0.03 & -0.53 & .595 & {$[-0.51,0.29]$} \\
Tenure (Org.) & 0.02 & 1.33 & 0.00 & 0.02 & .987 & {$[-2.59,2.63]$} \\
Tenure (RN) & 0.16 & 1.51 & 0.01 & 0.11 & .914 & {$[-2.81,3.14]$} \\
Unit Type & 0.32 & 0.33 & 0.06 & 0.97 & .333 & {$[-0.33,0.97]$} \\
Role & 1.69 & 1.85 & 0.06 & 0.91 & .362 & {$[-1.95,5.33]$} \\
Magnet Desig. & 2.41 & 8.81 & 0.05 & 0.27 & .785 & {$[-14.94,19.75]$} \\
Magnet Jour. & -0.00 & 0.01 & -0.02 & -0.09 & .930 & {$[-0.02,0.02]$} \\
Location & 4.97 & 3.99 & 0.08 & 1.25 & .214 & {$[-2.88,12.83]$} \\
Adult & 6.42 & 3.55 & 0.11 & 1.81 & .072 & {$[-0.57,13.41]$} \\
Pediatric & 0.33 & 3.29 & 0.01 & 0.10 & .919 & {$[-6.15,6.81]$} \\
Trauma & 1.34 & 3.77 & 0.02 & 0.36 & .721 & {$[-6.07,8.76]$} \\
Teaching & -1.15 & 3.42 & -0.02 & -0.34 & .737 & {$[-7.89,5.59]$} \\
Community & -2.95 & 3.46 & -0.05 & -0.85 & .394 & {$[-9.75,3.85]$} \\
Size & -0.19 & 1.16 & -0.01 & -0.16 & .873 & {$[-2.48,2.11]$} \\
State & 0.03 & 0.12 & 0.02 & 0.28 & .781 & {$[-0.20,0.27]$} \\
\hline
\end{tabular}

Note. $\left.F(17,286)=0.57, p=.910, R^{2}=0.18\right)$

Table 13. Multiple Regression of Organizational Characteristics and Nurse Attributes on Perception of Medication Errors 


\section{Chapter 5}

\section{Discussion}

Nurses have taken on more responsibility with less available resources, which can severely impact engagement in their role, organization and profession (KutneyLee et al., 2009). Scholars from both nursing and economics reveal a direct association between nurse engagement and patient complications and mortality (Aiken et al., 2012; Duffield et al., 2011; Needleman et al., 2002). In fact, according to Charmel et al. (2008), organizations with low nurse engagement pay out significantly more in malpractice claims than organizations with high nurse engagement.

Adverse drug events (ADEs) due to medication errors further contribute to the rising cost of healthcare. According to the 2001 Institute of Medicine (IOM) report To Err is Human: Building A Safer Health System, roughly two out of every 100 admissions experience a preventable $\mathrm{ADE}$, at an expense of approximately $\$ 2$ billion annually (Kohn et al., 2000). The most recent findings indicate that 3.42 out of every 100 admissions experience a preventable ADE, at an expense of $\$ 2.7$ billion to $\$ 5.1$ billion annually (CDC, 2014; Lahue, Iwasaki, Blumen, Forray, \& Rothschild, 2012). Although it appears that preventable ADEs have become worse since the landmark IOM report, the implementation of Computerized Physician Order Entry (CPOE) software, tall-man lettering and barcoding technology have assisted in reducing some preventable ADEs (Bootman, Wolcott, Aspden \& Cronenwett, 2006). It is believed that along with the aids listed above, the ability to report and/or track medication 
errors has increased over time, thus leading to a somewhat more realistic picture of the crisis at hand (Bootman et al., 2006).

Organizations rely on the accurate reporting of medication errors or omissions by bedside nurses to improve the medication delivery system - prescription to administration, in order to prevent further errors from occurring in the future. Unfortunately, studies show that many nurses do not report medication errors either for fear of disciplinary action or for lack of understanding of what constitutes a medication error (Hewitt, 2010). With higher acuity patients and less resources for nurses, this continues to be a significant topic for the nursing profession.

The purpose of this non-experimental, cross-sectional correlational study was to test an investigator developed conceptual model to determine if relationships exist between organizational commitment (OC), organizational-based self-esteem (OBSE), work engagement and nurses' perception of medication errors from a sample of RNs who work in a acute care facilities throughout the United States. The first aim for this study included describing nurse characteristics (attributes), organizational (facility) characteristics; and the constructs of organizational commitment, OBSE, work engagement and nurses' perception of medication errors. The second aim was to test the investigator developed conceptual model. The third and fourth aims set out to test the relationship of nurse and organizational characteristics on nurses' perception of medication errors. Each of these aims will be discussed next.

\section{$\operatorname{Aim} 1$}

The first aim of this study was to describe organizational commitment (affective, normative and continuance commitment), OBSE, work engagement (vigor, 
absorption and dedication), organizational characteristics (facility type; magnet status; size and geographic location), nurse characteristics (age; education; unit type, hours worked and role; and tenure in organization and profession), and nurses' perception of medication errors.

\section{Organizational Commitment}

The latent construct of organizational commitment was conveyed through the use of Allen and Meyer's (1990) Three-Component Model of Employee Commitment Survey. The survey consists of three scales, each measuring one component of the three-component model. All three scales include six items, and are all measured on a five-point disagree-agree Likert response scale $(1=$ Strongly Agree; 5 = Strongly Disagree). Some items were reversed keyed to prevent response bias. There are a total of 18 items for this instrument, six items for each scale.

The first scale in this instrument is the affective commitment scale $(A C)$. As reviewed in chapter two, affective commitment is based on the emotional attachment that an employee has with the organization. Participants in the study had a mean score of $2.19(0.69)$ for this observed variable. The second scale is the normative commitment scale $(N C)$. Normative commitment occurs when employees feel a sense of obligation to their organization and stay because it is the right thing to do. Participants in the study had a mean score of $2.51(0.75)$ for this observed variable. The third scale is the continuance commitment scale (CC). Continuance commitment is based on the costs associated with leaving an organization. Participants in the study had a mean score of $3.15(.70)$ for this observed variable. The mean scores for AC, $\mathrm{NC}$ and $\mathrm{CC}$ remained consistent with previous studies that have used this instrument 
(Somers, 2009; Lum, Kervin, Clark, Reid \& Sirola, 1998; Powell et al., 2004).

Overall, scores for Organizational Commitment (OC) revealed that participants are committed to their organizations, but do not necessarily feel compelled (due to the costs associated with leaving) to stay if a better opportunity arises.

Confirmation of the relationship of organizational commitment (latent construct) to its observed factors through standardized regression showed significance when OC was regressed on $\mathrm{AC}, \mathrm{NC}$, and $\mathrm{CC}$. The standardized regression path for $\mathrm{AC}$ was 0.77 $(p<.001)$. For NC, the standardized path was $0.75(p<.001)$. For CC, the standardized path was $0.30(p<.001)$. This indicates that there is a positive relationship between $\mathrm{OC}, \mathrm{AC}, \mathrm{NC}$, and $\mathrm{CC}$, which is consistent with previous studies using this instrument.

\section{Organizational Based Self Esteem}

The organizational-based self-esteem survey developed by Pierce et al. in 1989 is the most widely used scale for organizational-based self-esteem. The scale contains 10 items measured on a five point Likert-type disagree-agree scale $(1=$ Strongly Agree; 5 = Strongly Disagree). Participants in this study had a mean score of 1.75 (0.83) for this single factor construct. The mean scores for this study are consistent with previous studies that have used this instrument (Carson et al., 1997; Gardner et al., 2004; Hui et al., 2000). Overall, most participants had relatively high self-esteem as related to work and organizational experiences.

\section{Nurse Work Engagement}

The Utrecht work engagement survey developed by Schaufeli et al. in 2003 has been extensively used in business, psychology, sociology and healthcare research. 
The survey is also referred to the "Work and Well-being Survey". The survey contains 17 statements that are measured on a seven-point never-always Likert response scale $(0=$ Never; $6=$ Always $)$. The 17 statements cover the three engagement dimensions of vigor (6 items), dedication (5 items) and absorption (6 items) outlined in chapter two. The first dimension, vigor, is described as the energy and enthusiasm one brings to his/her work, and the resilience and persistence to overcome work-related challenges (Schaufeli et al., 2004; Spence-Laschinger, Wilk, Cho \& Greco, 2009). Participants in the study had a mean score of $4.35(0.74)$ for this factor. The second dimension, dedication, is described as the pride, inspiration and sense of significance one brings to his/her work (Schaufeli et al., 2004; SpenceLaschinger et. al, 2009). Participants in the study had a mean score of 4.94 (0.71) for this factor. The final dimension, absorption, refers to the feeling one gets when time passes quickly while immersed in his/her work (Schaufeli et al., 2004; SpenceLaschinger et al., 2009). Participants in the study had a mean score of 4.18 (0.71) for this factor. The mean scores for this study are consistent with a study conducted by Bakker, Hakanen, Demerouti \& Xanthopoulou (2007) and slightly higher than Lawrence's (2011) study of ICU nurses.

Confirmation of the relationship of nurse work engagement (latent construct) to its observed factors through standardized regression showed significance when NWE was regressed on Absorption, Dedication and Vigor. The standardized regression path for Absorption was $0.76(p<.001)$. For Dedication, the standardized regression path was $0.78(p<.001)$. For Vigor, the standardized path was $0.91(p<$ 
.001). This indicates that there was a positive relationship between NWE, Absorption, Vigor, and Dedication.

\section{Organizational (Facility) Characteristics}

A detailed description of organizational characteristics for the participant sample was provided in Chapter 4. Overall, a majority of participants worked in large $(n=121,34.5 \%)$ urban $(n=271,77.2 \%)$ Magnet designated $(n=217,61.8 \%)$ facilities. This is not surprising considering a majority of participants were recruited to participate in the study from the annual Magnet convention.

\section{Nurse (Attributes) Characteristics}

A detailed description of nurse characteristics for the participant sample was provided in Chapter 4. Overall, a total of 351 participants took part in this study, with an average age of $38(S D=9.87)$ and $38.27(S D=7.51)$ average hours worked per week. The majority of the sample had a BSN degree $(n=236,67.6 \%)$ as their highest degree, had 4 to 6 years $(n=71,20.3 \%)$ of tenure as a nurse, and had been with their organization between 1 and 3 years $(n=92,26.2 \%)$. The largest role that the participants had was a Bedside/Charge $\mathrm{RN}(n=168,48.6 \%)$ and most of the participants worked in either the Medical/Surgical unit $(n=72,20.8 \%)$ or the Neonatal ICU unit ( $n=69,19.9 \%)$. The large number of NICU respondents may be due to recruitment of participants and the annual National Association of Neonatal Nurses conference, slightly skewing the distribution of units represented. Nurses' Perception of Medication Errors

The Modified Gladstone Survey, adapted by Osborne et al. (1999) from Gladstone's (1995) questionnaire, has been reliably used to determine nurses' 
perception of medication errors. The survey consists of 27 items. The first 14 items in the survey address nurses' perception of medication errors; the remaining 13 items are demographic questions that were not used for this study. Survey responses for this instrument include ranking 10 statements (1-10) as to the frequency of medication errors ("most frequent" = 1 to "least frequent" = 10) (1 item); nurse's estimation of percentage of medication errors reported to nurse managers: " $x$ " marked on a line from $1 \%-100 \%(1$ item); medication error scenarios asking the nurse to identify a possible medication error, and if it warranted reporting to the physician and/or nurse manager (6 items); and "yes/no" questions on views of medication error reporting (6 items). Overall, participants in the study believe that $58.75 \%$ (26.13) of medication errors are reported to nurse managers through the completion of an incident report. A detailed discussion and results of this instrument were provided in Chapter 4.

\section{$\operatorname{Aim} 2$}

The second aim in this study was to test the proposed conceptual structural equation model asserting that relationships are present between organizational commitment (affective, normative and continuance commitment), OBSE, nurse work engagement (vigor, dedication and absorption) and nurses' perception of medication errors as presented in Figure 1. 


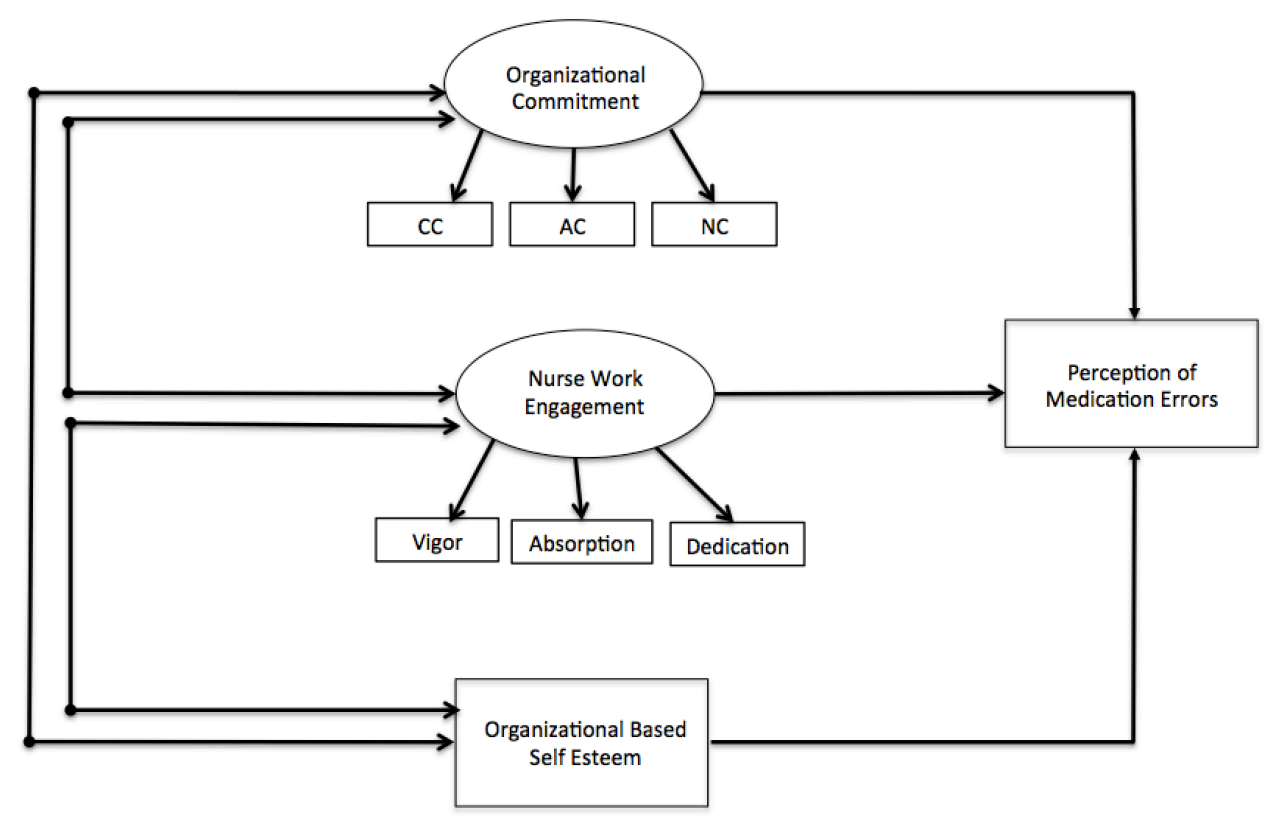

Figure 1 - Proposed Structural Equation Model

In order to test whether or not the observed and latent variables were a good fit for the model, a confirmatory factor analysis was done (CFA). Composite scores were created for $\mathrm{AC}, \mathrm{CC}$, and $\mathrm{NC}$ by creating a mean score, which all made up one latent variable - Organizational Commitment (OC). Composite mean scores were also created for Vigor, Dedication, and Absorption, which made up the latent variable - Nurse Work Engagement (NWE). Finally, the composite mean score for OBSE was created and left as its own observed variable in the model.

The initial results of the model did not show good fit. However, after looking at the modification indices and adding covariations to the model, the model fit improved greatly. Model fit for the model with the modification indices showed acceptable model fit overall.

Once an acceptable model fit was established with the CFA, a structural equation model (SEM) was created. Again, the initial results of the model did not 
indicate a good fit, however the modification indices were assessed and indicated that several covariations could be added to the model in order to improve the model fit. The covariations were added and the model was tested again and the model fit improved greatly. Once an acceptable model fit was established, the composite reliability was tested for each of the latent variables. Both $\mathrm{OC}(C R=.79)$ and NWE $(C R=.92)$ showed at least good reliability. The independent measures were then correlated to see if there was a relationship among the variables. OC showed a medium negative relationship with NWE $(r=-0.43)$, but a weak positive relationship with OBSE $(r=0.13)$. NWE also showed a weak negative relationship with OBSE $(r$ $=-0.13)$. Finally, the regression weights showed that there was no relationship between $\mathrm{OC}, \mathrm{NWE}$, and PME (both $p$ 's > .05). However, there was a weak negative relationship between OBSE and PME ( $p=.010)$ (See Table 12 and Figure 2).

Table 12

\begin{tabular}{|c|c|c|c|c|}
\hline Regression & $B$ & $S E$ & $Z$ & $P$ \\
\hline $\mathrm{PME} \sim \mathrm{OC}$ & -0.55 & 3.36 & -0.82 & .417 \\
\hline $\mathrm{PME} \sim \mathrm{NWE}$ & 0.12 & 2.53 & 1.85 & .064 \\
\hline $\mathrm{PME} \sim \mathrm{OBSE}$ & -0.14 & 1.68 & -2.57 & $.010^{*}$ \\
\hline \multicolumn{5}{|l|}{$\mathrm{OC}$} \\
\hline $\mathrm{NC}$ & 0.75 & 0.17 & 6.10 & $<.001^{*}$ \\
\hline $\mathrm{CC}$ & 0.30 & 0.10 & 3.68 & $<.001^{*}$ \\
\hline AC & 0.77 & 0.16 & 6.10 & $<.001^{*}$ \\
\hline \multicolumn{5}{|l|}{ NWE } \\
\hline Dedication & 0.78 & 0.05 & 15.67 & $<.001^{*}$ \\
\hline Absorption & 0.76 & 0.06 & 14.71 & $<.001^{*}$ \\
\hline Vigor & 0.91 & 0.08 & 15.67 & $<.001^{*}$ \\
\hline
\end{tabular}

Note. $*$ Indicates a significant relationship. PME $=$ Perception of Medication Error, OC $=$ Organizational Commitment, NWE $=$ Nurse Work Engagement, $\mathrm{NC}=$ Normative Commitment, $\mathrm{CC}=$ Continuous Commitment, $\mathrm{AC}=$ Affective Commitment.

Table 12. Standardized Regression Paths 


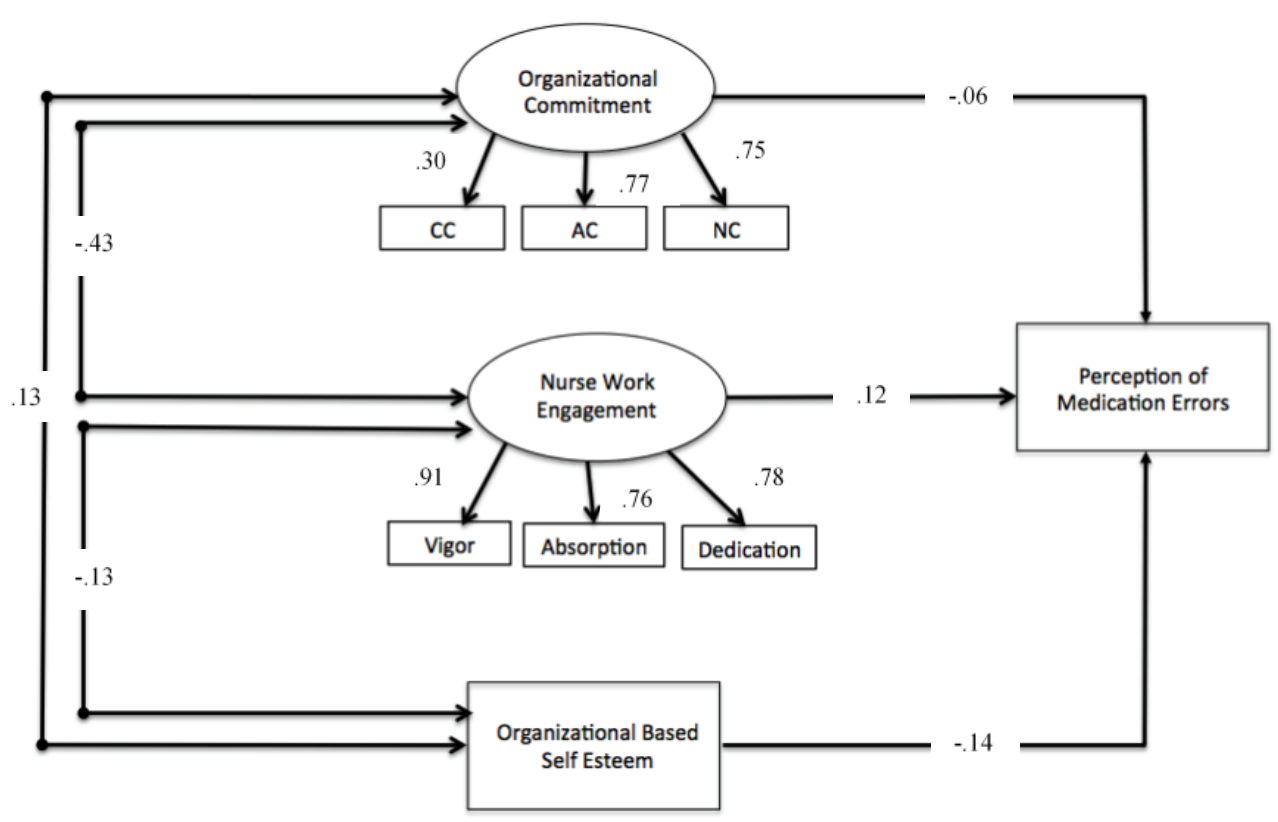

Figure 2. Structural Equation Model with Regression Weights

This study is the first of its kind to evaluate the relationships between organizational commitment, nurse work engagement and OBSE on nurses' perception of medication errors. Through an investigator-designed conceptual model, it was hypothesized that OC and OBSE will have a positive effect on nurse work engagement and perception of medication errors. It was surprising to see that no significant relationships existed between organizational commitment, nurse work engagement and nurses' perception of medication errors. Even more surprising is the significant negative relationship between OBSE and nurses' perception of medication errors, suggesting that as OBSE increases, perceived medication error reporting decreases.

Revisiting the concept of OBSE from Chapter 2, OBSE can be defined as the degree to which an employee feels that he/she is a capable, significant and worthy member of an organization (Pierce et al., 1989; Peirce et al., 2004; Gardner et al., 
2014; Chen et al., 2015). It is possible that as a nurse feels more secure in the work environment, the more realistic he/she may be about the shortcomings of the organization - in this case, perceived medication error reporting. Further studies are needed using the OBSE instrument in the nursing population.

\section{Aim 3 and Aim 4}

The last two aims of this study were to test the relationship of organizational (facility) characteristics - facility type; magnet status; size and geographic location (Aim 3) and nurse (attributes) characteristics - age; education; unit type, hours worked and role; and tenure in organization and profession (Aim 4) on nurses' perception of medication errors. To satisfy these aims, a multiple regression was used to see if there was a relationship between the demographic variables of organizational characteristics and nurse attributes and perceived medication errors. The results of the overall model were not statistically significant ( $p$ $=.918)$. The results suggest that there is no relationship between organizational characteristics, nurse attributes, and perceived medication errors. The results of the regression are presented in Table $\mathbf{1 3 .}$

Since this was the first study of its kind to look at the relationship between facility characteristics and nurses' perception of medication errors, it was interesting that not a single organization (facility) characteristic, such as Magnet status, had any impact on nurses' perception of medication errors. Although no other studies could be identified looking at facility characteristics and perception of medication errors, a similar study conducted by Mills and Gillespie (2013) set out to identify differences in failure to rescue and ulcer rates between Magnet and non-Magnet hospitals. In their 
study, Mills et al. (2013) were also unable to differentiate between facility characteristics, including Magnet status regarding the two nursing-sensitive outcomes in question. Further studies are needed to continue to add to the knowledge gap pertaining to the role facility characteristics play in patient-centered outcomes. The relationship between nursing attributes and medication errors have been analyzed in other studies. To date, no studies have found a significant relationship between a single nursing attribute such as education or tenure in the profession and perception of medication errors (Mayo et al., 2004; Maiden et al., 2011; Mahmood et al., 2011; Osborne et al., 1999). This study confirms previous findings and adds to the literature recommending that all nurses, regardless of education or tenure, continue to be educated in identifying and reporting medication errors in their workplace. 
Table 13

\begin{tabular}{lcccccc}
\hline \multicolumn{1}{c}{ Model } & $B$ & $S E$ & $\mathrm{~B}$ & $t$ & $p$ & $95 \%$ CI \\
\hline Age & 0.09 & 0.28 & 0.03 & 0.31 & .758 & {$[-0.47,0.64]$} \\
Nursing & -0.28 & 2.35 & -0.01 & -0.12 & .905 & {$[-4.91,4.35]$} \\
Degree & & & & & & \\
Hours/Week & -0.11 & 0.21 & -0.03 & -0.53 & .595 & {$[-0.51,0.29]$} \\
Tenure (Org.) & 0.02 & 1.33 & 0.00 & 0.02 & .987 & {$[-2.59,2.63]$} \\
Tenure (RN) & 0.16 & 1.51 & 0.01 & 0.11 & .914 & {$[-2.81,3.14]$} \\
Unit Type & 0.32 & 0.33 & 0.06 & 0.97 & .333 & {$[-0.33,0.97]$} \\
Role & 1.69 & 1.85 & 0.06 & 0.91 & .362 & {$[-1.95,5.33]$} \\
Magnet Desig. & 2.41 & 8.81 & 0.05 & 0.27 & .785 & {$[-14.94,19.75]$} \\
Magnet Jour. & -0.00 & 0.01 & -0.02 & -0.09 & .930 & {$[-0.02,0.02]$} \\
Location & 4.97 & 3.99 & 0.08 & 1.25 & .214 & {$[-2.88,12.83]$} \\
Adult & 6.42 & 3.55 & 0.11 & 1.81 & .072 & {$[-0.57,13.41]$} \\
Pediatric & 0.33 & 3.29 & 0.01 & 0.10 & .919 & {$[-6.15,6.81]$} \\
Trauma & 1.34 & 3.77 & 0.02 & 0.36 & .721 & {$[-6.07,8.76]$} \\
Teaching & -1.15 & 3.42 & -0.02 & -0.34 & .737 & {$[-7.89,5.59]$} \\
Community & -2.95 & 3.46 & -0.05 & -0.85 & .394 & {$[-9.75,3.85]$} \\
Size & -0.19 & 1.16 & -0.01 & -0.16 & .873 & {$[-2.48,2.11]$} \\
State & 0.03 & 0.12 & 0.02 & 0.28 & .781 & {$[-0.20,0.27]$} \\
\hline
\end{tabular}

Note. $\left.F(17,286)=0.57, p=.910, R^{2}=0.18\right)$

Table 13. Multiple Regression of Organizational Characteristics and Nurse Attributes on Perception of Medication Errors

\section{Limitations}

As with any research study, this study has limitations that should be addressed. First, the participant sample was fairly homogenous due to participant recruitment at two national nursing conventions. A majority of nurse participants in the study came from large, urban and Magnet designated hospitals with potentially larger budgets for staffing, education programs and error reporting systems. Thus, the findings in this study may not be generalizable to all nurses in all facilities around the United States. Second, the survey created for this study was composed of four instruments and a demographic questionnaire totaling roughly 100 items. Although 
most respondents completed the survey in 15 minutes, participant fatigue may have skewed some participant responses, especially at the end of the survey.

\section{Implications}

\section{Clinical Nursing Practice}

This study is the first of its kind to evaluate the relationships between organizational commitment, nurse work engagement and OBSE on nurses' perception of medication errors. Since the IOM's landmark report, many important changes such as $\mathrm{CPOE}$, medication and patient barcoding, tall-man lettering and patient safety programs have been implemented. Despite these efforts, medication errors continue to occur. Similar to the Mayo et al. (2004) study, nurses in this study are experiencing a gap between perceived knowledge and actual knowledge. For example, $88 \%$ of nurses in this study believed they knew what constituted a medication error, but when presented with medication error scenarios, they were somewhat inconsistent with their responses to the medication error scenarios. With nurses on the front lines, this continues to be concerning. To assist in bridging the gap between perceived and actual knowledge of what constitutes a medication error, the profession as a whole needs to agree on a single definition and work to educate all nurses.

\section{Education}

Nursing students begin their nursing education with a pharmacology course and medication calculation tests. To supplement their education, students are brought into the clinical environment to build their medication administration skills. It is at this critical time in learning that an agreed upon definition of what constitutes a medication error should be presented and discussed. In addition, nurses - novice to 
expert - should undergo scenario-based medication error questions and debriefings as part of onboarding and continuing education on an annual basis. Literature has shown that when a medication error strikes a patient, it is usually due to a breakdown in the system or process of medication administration. Nurses, however, are the last line of defense before an error strikes and thus hold the trust of the patient and family, along with the entire system, to protect against a medication error.

\section{Leadership}

When asked if a medication error was not reported out of fear for disciplinary action or loss of a job, the majority of participants in this study $(n=280,79.8 \%)$ said they had not ever failed to report a medication error out of personal fear. Although this is encouraging, there is still work to be done by supervisors, managers and directors to facilitate ongoing discussions around the area of medication errors including omissions and near misses. The more this topic is embraced by leadership and discussed openly by the team members, the less hesitant a staff member will be to report an error if one should come up. Furthermore, leadership, staff members and the multidisciplinary team need to work together to develop an easily accessible, nonthreatening and user-friendly method of error reporting that can be agreed upon by all stakeholders.

\section{Research}

This study was conducted to test the relationships of multiple variables on nurses' perception of medication errors. At the completion of this study, a couple of suggestions for further research have become apparent. First, during the study, a number of nurses suggested that they failed to report an error due to the cumbersome 
error reporting system at their facility. Future research in this area should include a qualitative component designed to address topics around error reporting, such as poorly designed systems and other barriers to system-wide reporting.

Second, this study provided an introduction to the area of OBSE in the nursing profession as related to work engagement, organizational commitment and perception of medication errors. As the only variable that provided a significant relationship to perception of medication errors, it is imperative that more studies are conducted looking at organizational based self-esteem as a possible cause of underreported medication errors, near misses and omissions. OBSE may also be the missing link to many unanswered questions in other nursing-related outcomes research and warrants a closer look, especially in the areas of nursing engagement, turnover and patient safety.

\section{Conclusion}

No one on the healthcare team works in a silo. Medication errors result from a breakdown in the medication delivery system. This systemic breakdown can only be fixed if all medication errors - including near misses and omissions - are reported by all members of the multidisciplinary team in real time. With accurate reporting, education programs can be tailored and solutions proposed at each phase in the medication delivery process to fix gaps in the system. Patient safety is everyone's responsibility - knowledge is power. 


\section{References}

Abdelhadi, N., \& Drach-Zahavy, A. (2012). Promoting patient care: work engagement as a mediator between ward service climate and patient-centered care. Journal of advanced nursing, 68(6), 1276-1287.

Aiken, L., Sermeus, W., Van den Heede, K., Sloane, D., Busse, R., \& McKee, M. et al. (2012). Patient safety, satisfaction, and quality of hospital care: cross sectional surveys of nurses and patients in 12 countries in Europe and the United States. BMJ, 344(mar20 2), e1717-e1717. doi:10.1136/bmj.e1717

Allen, N. J., \& Meyer, J. P. (1990). The measurement and antecedents of affective, continuance and normative commitment to the organization. Journal of occupational psychology, 63(1), 1-18.

Allen, N. J., \& Meyer, J. P. (1996). Affective, continuance, and normative commitment to the organization: An examination of construct validity. Journal of vocational behavior, $49(3), 252-276$.

Bakker, A. B., \& Demerouti, E. (2008). Towards a model of work engagement. Career development international, 13(3), 209-223.

Bakker, A. B., Hakanen, J. J., Demerouti, E., \& Xanthopoulou, D. (2007). Job resources boost work engagement, particularly when job demands are high. Journal of educational psychology, 99(2), 274.

Bakker, A. B., \& Schaufeli, W. B. (2008). Positive organizational behavior: Engaged employees in flourishing organizations. Journal of Organizational Behavior, 29(2), $147-154$.

Becker, H. S. (1960). Notes on the concept of commitment. The American Journal of 
Sociology, 66(1), 32-40.

Blizzard, D. B. A. (2002). Nurses may be satisfied, but are they engaged. http://www.gallup.com/poll/6004/Nurses-May-Satisfied-They-Engaged.aspx? Accessed May 28, 2015.

Bootman, J. L., Wolcott, J., Aspden, P., \& Cronenwett, L. R. (Eds.). (2006).Preventing Medication Errors: Quality Chasm Series. National Academies Press.

Bowling, N. A., Eschleman, K. J., Wang, Q., Kirkendall, C., \& Alarcon, G. (2010). A meta analysis of the predictors and consequences of organization - based self - esteem. Journal of Occupational and Organizational Psychology, 83(3), 601-626.

Carson, K. D., Carson, P. P., Lanford, H., \& Roe, C. W. (1997). The effects of organizationbased self-esteem on workplace outcomes: An examination of emergency medical technicians. Public Personnel Management, 26(1), 139-155.

Carter, M. R., \& Tourangeau, A. E. (2012). Staying in nursing: what factors determine whether nurses intend to remain employed? Journal of advanced nursing, 68(7), 1589-1600.

CDC/National Center for Health Statistics (2014). Hospital Utilization in Non- Federal Short Stay Hospitals. Retrieved January 16, 2016 from: http://www.cdc.gov/nchs/fastats/hospital.htm

Charmel, P. A., \& Frampton, S. B. (2008). Building the business case for patient-centered care. Hfm (Healthcare Financial Management), 62(3), 80-85.

Chen, M. F., Ho, C. H., Lin, C. F., Chung, M. H., Chao, W. C., Chou, H. L., \& Li, C. K. (2015). Organization-based self-esteem mediates the effects of social support and job satisfaction on intention to stay in nurses. Journal of nursing management. 
Chughtai, A., \& Buckley, F. (2011). Work engagement. Career Dev Int, 16(7), 684-705. doi:10.1108/13620431111187290

Cohen, A. (2007). Commitment before and after: An evaluation and reconceptualization of organizational commitment. Human Resource Management Review, 17(3), 336-354.

Cohen, M. (2007). Medication errors. Washington, D.C.: American Pharmacists Association.

De Gieter, S., Hofmans, J., \& Pepermans, R. (2011). Revisiting the impact of job satisfaction and organizational commitment on nurse turnover intention: An individual differences analysis. International journal of nursing studies, 48(12), 1562-1569.

Duffield, C., Diers, D., O'Brien-Pallas, L., Aisbett, C., Roche, M., King, M., \& Aisbett, K. (2011). Nursing staffing, nursing workload, the work environment and patient outcomes. Applied Nursing Research, 24(4), 244-255.

doi:10.1016/j.apnr.2009.12.004

Erdheim, J., Wang, M., \& Zickar, M. J. (2006). Linking the Big Five personality constructs to organizational commitment. Personality and Individual Differences, 41(5), 959970

Fasoli, D. R. (2010). The culture of nursing engagement: A historical perspective. Nursing Administration Quarterly, 34(1), 18-29.

Fiorito, J., Bozeman, D. P., Young, A., \& Meurs, J. A. (2007). Organizational commitment, human resource practices, and organizational characteristics. Journal of Managerial Issues, 186-207.

Fry, M., \& Dacey, C. (2007). Factors contributing to incidents in medicine administration. Part 1. British journal of nursing, 16(9), 556-559. 
Gardner, D. G., Huang, G. H., Niu, X., Pierce, J. L., \& Lee, C. (2014). Organization-Based Self-Esteem, Psychological Contract Fulfillment, and Perceived Employment Opportunities: A Test of Self-Regulatory Theory. Human Resource Management.

Gardner, D. G., \& Pierce, J. L. (2011). A question of false self-esteem: Organization-based self-esteem and narcissism in organizational contexts. Journal of Managerial Psychology, 26(8), 682-699.

Gardner, D. G., van Dyne, L., \& Pierce, J. L. (2004). The effects of pay level on organization-based self-esteem and performance: A field study. Journal of Occupational and Organizational Psychology, 77(3), 307-322.

George, D. \& Mallery, P. (2010). SPSS for Windows Step by Step: A Simple Study Guide and Reference, 18.0 Update. Boston: Allyn \& Bacon.

Gladstone, J. (1995). Drug administration errors: a study into the factors underlying the occurrence and reporting of drug errors in a district general hospital. J Adv Nurs, 22(4), 628-637. doi:10.1046/j.1365-2648.1995.22040628.x

Hair Jr, J. F., Hult, G. T. M., Ringle, C., \& Sarstedt, M. (2013). A primer on partial least squares structural equation modeling (PLS-SEM). Sage Publications.

Hewitt, P. (2010). Clinical Practice Nurses' Perceptions of the Causes of Medication Errors: An Integrative Literature Review. Medsurg Nursing, 19(3), 159.

Hoyle, R. (2012). Handbook of structural equation modeling. New York, N.Y: Guilford. Hu, L. T., \& Bentler, P. M. (1999). Cutoff criteria for fit indexes in covariance structure analysis: Conventional criteria versus new alternatives. Structural equation modeling: a multidisciplinary journal, 6(1), 1-55. 
Hui, C., \& Lee, C. (2000). Moderating effects of organization-based self-esteem on organizational uncertainty: Employee response relationships. Journal of Management, 26(2), 215-232.

Irving, P. G., Coleman, D. F., \& Cooper, C. L. (1997). Further assessments of a threecomponent model of occupational commitment: Generalizability and differences across occupations. Journal of applied psychology, 82(3), 444.

Kanning, U. P., \& Hill, A. (2012). Organization-based self-esteem scale-adaptation in an international context. Journal of Business and Media Psychology, 3, 13-21.

Kanter, R. M. (1968). Commitment and social organization: A study of commitment mechanisms in utopian communities. American sociological review, 499-517.

Kavanagh, K., Cimiotti, J., Abusalem, S., \& Coty, M. (2012). Moving Healthcare Quality Forward With Nursing-Sensitive Value-Based Purchasing. Journal Of Nursing Scholarship, 44(4), 385-395. doi:10.1111/j.1547-5069.2012.01469.x

Kline, R. (2011). Principles and practice of structural equation modeling. New York: Guilford Press.

Ko, J. W., Price, J. L., \& Mueller, C. W. (1997). Assessment of Meyer and Allen's threecomponent model of organizational commitment in South Korea. Journal of applied psychology, 82(6), 961.

Korman, A. K. (1970). Toward an hypothesis of work behavior. Journal of Applied Psychology, 54(1p1), 31.

Kutney-Lee, A., McHugh, M., Sloane, D., Cimiotti, J., Flynn, L., Neff, D., \& Aiken, L. (2009). Nursing: A Key To Patient Satisfaction. Health Affairs, 28(4), w669-w677. doi:10.1377/hlthaff.28.4.w669 
Lahue, B. J., Pyenson, B., Iwasaki, K., Blumen, H. E., Forray, S., \& Rothschild, J. M. (2012). National burden of preventable adverse drug events associated with inpatient injectable medications: healthcare and medical professional liability costs. American health \& drug benefits, 5(7), 1.

Lapointe, É., Vandenberghe, C., \& Panaccio, A. (2011). Organizational commitment, organization-based self-esteem, emotional exhaustion and turnover: A conservation of resources perspective. Human Relations, 64(12), 1609-1631.

Laschinger, H. K., Wilk, P., Cho, J., \& Greco, P. (2009). Empowerment, engagement and perceived effectiveness in nursing work environments: does experience matter?. Journal of Nursing Management, 17(5), 636-646.

Lawrence, L. A. (2011, October). Work engagement, moral distress, education level, and critical reflective practice in intensive care nurses. In Nursing Forum (Vol. 46, No. 4, pp. 256-268).

Lum, L., Kervin, J., Clark, K., Reid, F., \& Sirola, W. (1998). Explaining nursing turnover intent: job satisfaction, pay satisfaction, or organizational commitment?. Journal of Organizational Behavior, 19(3), 305-320.

Mahmood, A., Chaudhury, H., \& Valente, M. (2011). Nurses' perceptions of how physical environment affect medication errors in acute care settings. Applied Nursing Research, 24(4), 229-237.

Maiden, J., Georges, J. M., \& Connelly, C. D. (2011). Moral distress, compassion fatigue, and perceptions about medication errors in certified critical care nurses. Dimensions of Critical Care Nursing, 30(6), 339-345. 
Maslach, C., Schaufeli, W. B., \& Leiter, M. P. (2001). Job burnout. Annual review of psychology, 52(1), 397-422.

Mathieu, J. E., \& Zajac, D. M. (1990). A review and meta-analysis of the antecedents, correlates, and consequences of organizational commitment. Psychological bulletin, 108(2), 171.

Mayo, A. M., \& Duncan, D. (2004). Nurse perceptions of medication errors: what we need to know for patient safety. Journal of nursing care quality, 19(3), 209-217.

McAllister, D. J., \& Bigley, G. A. (2002). Work context and the definition of self: How organizational care influences organization-based self-esteem. Academy of Management Journal, 45(5), 894-904.

McCoach, D. B., Gable, R. K., \& Madura, J. P. (2013). Instrument development in the affective domain. New York, NY: Springer.

Meyer, J. P., \& Allen, N. J. (1984). Testing the" side-bet theory" of organizational commitment: Some methodological considerations. Journal of applied psychology, 69(3), 372.

Meyer, J.P. and Allen, N.J. (1991). “A three-part conceptualization of organizational commitment." Human Resource Management Review, 1:61-89.

Meyer, J. P., Allen, N. J., \& Gellatly, I. R. (1990). Affective and continuance commitment to the organization: Evaluation of measures and analysis of concurrent and time-lagged relations. Journal of applied psychology, 75(6), 710.

Meyer, J. P., \& Allen, N. J. (2004). TCM employee commitment survey academic users guide 2004. London, Ontario, Canada: The University of Western Ontario, Department of Psychology. 
Meyer, J. P., \& Herscovitch, L. (2001). Commitment in the workplace: Toward a general model. Human resource management review, 11(3), 299-326.

Meyer, J. P., \& Parfyonova, N. M. (2010). Normative commitment in the workplace: A theoretical analysis and re-conceptualization. Human resource management review, 20(4), 283-294.

Meyer, J. P., Stanley, D. J., Herscovitch, L., \& Topolnytsky, L. (2002). Affective, continuance, and normative commitment to the organization: A meta-analysis of antecedents, correlates, and consequences. Journal of vocational behavior, 61(1), 2052.

Mills, A. C., \& Gillespie, K. N. (2013). Effect of Magnet hospital recognition on 2 patient outcomes. Journal of nursing care quality, 28(1), 17-23.

Mowday, R. T., Steers, R. M., \& Porter, L. W. (1979). The measurement of organizational commitment. Journal of vocational behavior, 14(2), 224-247.

National Coordinating Council for Medication Error Reporting and Prevention. (n.d.) What is a medication error? Retrieved from: http://www.nccmerp.org/about-medication-errors

Needleman, J., Buerhaus, P., Mattke, S., Stewart, M., \& Zelevinsky, K. (2002). NurseStaffing Levels and the Quality of Care in Hospitals. New England Journal Of Medicine, 346(22), 1715-1722. doi:10.1056/nejmsa012247

Ong, A. D., \& Van Dulmen, M. H. (Eds.). (2007). Oxford handbook of methods in positive psychology. New York: Oxford University Press.

Osborne, J., Blais, K., \& Hayes, J. S. (1999). Nurses' perceptions: when is it a medication error?. Journal of Nursing Administration, 29(4), 33-38. 
O'Shea, E. (1999). Factors contributing to medication errors: a literature review. J Clin Nurs, 8(5), 496-504. doi:10.1046/j.1365-2702.1999.00284.x

Panaccio, A., \& Vandenberghe, C. (2011). The Relationships of Role Clarity and Organization - Based Self - Esteem to Commitment to Supervisors and Organizations and Turnover Intentions. Journal of Applied Social Psychology, 41(6), 1455-1485.

Pierce, J. L., Gardner, D. G., Cummings, L. L., \& Dunham, R. B. (1989). Organization-based self-esteem: Construct definition, measurement, and validation. Academy of Management journal, 32(3), 622-648.

Pierce, J. L., \& Gardner, D. G. (2004). Self-esteem within the work and organizational context: A review of the organization-based self-esteem literature. Journal of management, 30(5), 591-622.

Polit, D., \& Beck, C. (2012). Nursing research. Philadelphia: Wolters Kluwer Health/Lippincott Williams \& Wilkins.

Powell, D. M., \& Meyer, J. P. (2004). Side-bet theory and the three-component model of organizational commitment. Journal of vocational behavior, 65(1), 157-177.

Raykov, T. (1997). Estimation of composite reliability for congeneric measures. Applied Psychological Measurement, 21(2), 173-184.

Rivera, R. R., Fitzpatrick, J. J., \& Boyle, S. M. (2011). Closing the RN engagement gap: which drivers of engagement matter?. Journal of Nursing Administration, 41(6), 265272.

Schaufeli, W. B., \& Bakker, A. B. (2003). UWES-Utrecht work engagement scale: test manual. Unpublished Manuscript: Department of Psychology, Utrecht University. 
Schaufeli, W. B., Salanova, M., González-Romá, V., \& Bakker, A. B. (2002). The measurement of engagement and burnout: A two sample confirmatory factor analytic approach. Journal of Happiness studies, 3(1), 71-92.

Sekiguchi, T., Burton, J. P., \& Sablynski, C. J. (2008). The role of job embeddedness on employee performance: the interactive effects with leader-member exchange and organization-based self-esteem. Personnel Psychology, 61(4), 761-792.

Simpson, M. R. (2009). Predictors of work engagement among medical-surgical registered nurses. Western journal of nursing research, 31(1), 44-65.

Solinger, O. N., Van Olffen, W., \& Roe, R. A. (2008). Beyond the three-component model of organizational commitment. Journal of applied psychology, 93(1), 70.

Somers, M. J. (2009). The combined influence of affective, continuance and normative commitment on employee withdrawal. Journal of Vocational Behavior, 74(1), 75-81.

Tavakol, M., \& Dennick, R. (2011). Making sense of Cronbach’s alpha. International Journal of Medical Education, 2, 53-55. http://doi.org/10.5116/ijme.4dfb.8dfd

Tillott, S., Walsh, K., \& Moxham, L. (2013). Encouraging engagement at work to improve retention: Sarah Tillott and colleagues explore how a social interaction tool can help managers recruit and retain staff, and boost patient care. Nursing Management, 19(10), 27-31.

Ulanimo, V. M., O'Leary-Kelley, C., \& Connolly, P. M. (2007). Nurses' perceptions of causes of medication errors and barriers to reporting. Journal of nursing care quality, $22(1), 28-33$.

US Department of Health and Human Services. (1979).The Belmont Report. Office for Human Research Protections (OHRP). Retrieved April 23, 2015. 
Wiener, Y. (1982). Commitment in organizations: A normative view. Academy of management review, 7(3), 418-428.

Wolf, E. J., Harrington, K. M., Clark, S. L., \& Miller, M. W. (2013). Sample size requirements for structural equation models an evaluation of power, bias, and solution propriety. Educational and psychological measurement, 73(6), 913-934. 


\section{APPENDIX A}

\section{Part I}

\section{Demographic Questionnaire}

Please answer the following questions below. Place fill in the blank or place a check mark or " $x$ " by the answer that best describes you. Thank you!

\section{About you:}

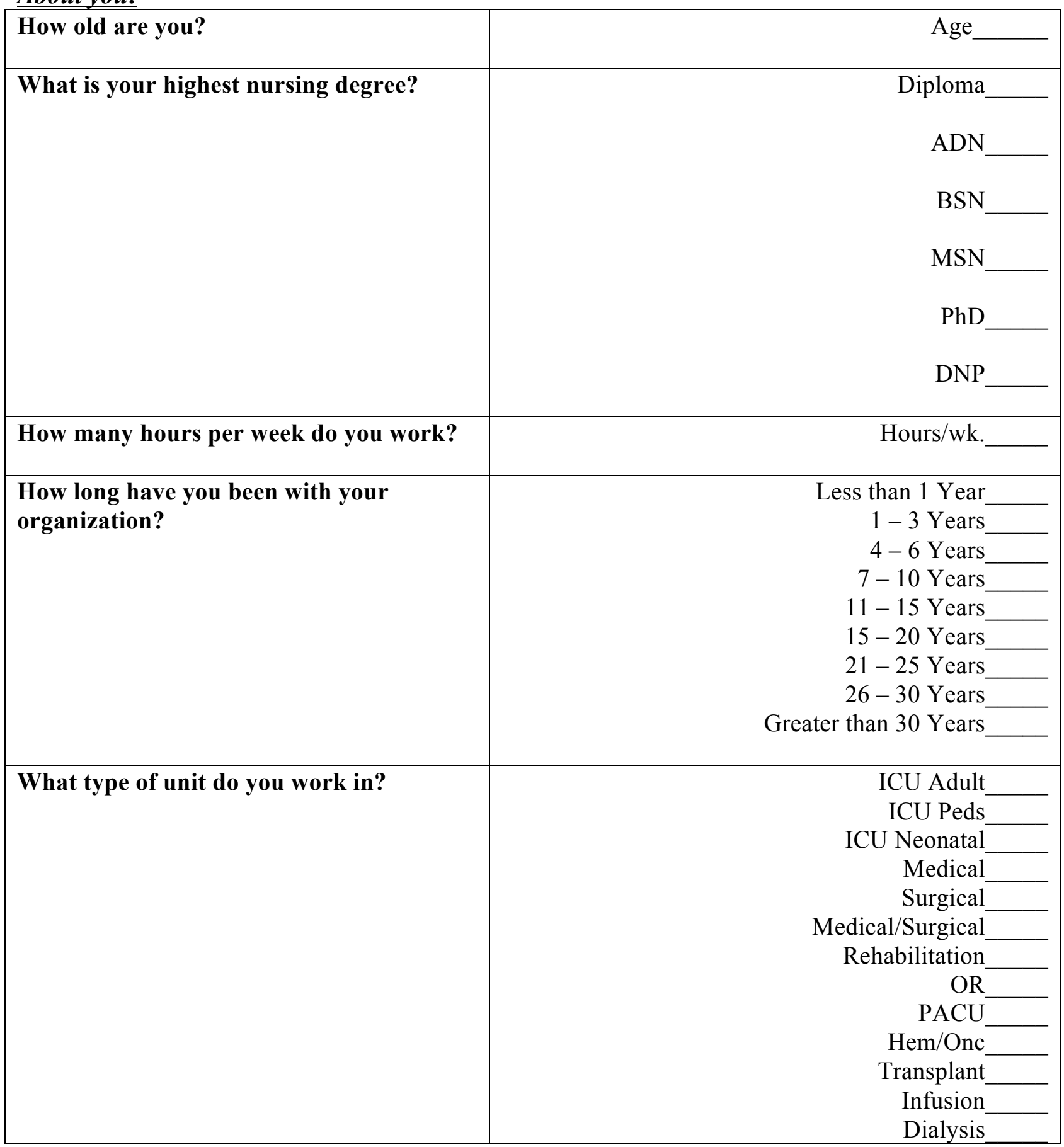




\begin{tabular}{|l|r|}
\hline What is your role in your unit? & Bedside RN \\
& Bedside / Charge RN_ \\
Resource RN_ & Educator / CNS \\
\hline How many years have you been an RN? & Other_ \\
\hline & Less than 1 Year_ \\
& $1-3$ Years \\
& $4-6$ Years \\
& $7-10$ Years \\
& $11-15$ Years \\
& $15-20$ Years \\
& $21-25$ Years \\
& $26-30$ Years \\
\hline
\end{tabular}

About your facility/organization:

\begin{tabular}{|c|c|}
\hline $\begin{array}{l}\text { Does your facility hold Magnet }{ }^{\circledR} \\
\text { designation? } \\
\text { If you answered no, is your } \\
\text { facility on the Magnet }{ }^{\circledR} \text { Journey? }\end{array}$ & $\begin{array}{l}\text { Yes } \\
\text { No } \\
\text { Yes } \\
\text { No }\end{array}$ \\
\hline $\begin{array}{l}\text { Is your facility located in a rural or } \\
\text { urban location? }\end{array}$ & $\begin{array}{l}\text { Rural } \\
\text { Urban }\end{array}$ \\
\hline In what State is your facility located? & State \\
\hline $\begin{array}{l}\text { What type of facility do you work in? } \\
\text { Check all that apply: }\end{array}$ & $\begin{array}{r}\text { Adult } \\
\text { Pediatrics } \\
\text { Trauma Designated } \\
\text { Teaching } \\
\text { Community }\end{array}$ \\
\hline $\begin{array}{l}\text { How large is your organization (in } \\
\text { beds)? }\end{array}$ & $\begin{array}{r}\text { Less than } 200 \\
200-300 \\
301-400 \\
401-500 \\
\text { Greater than } 500\end{array}$ \\
\hline
\end{tabular}




\section{APPENDIX B}

\section{Part II}

\section{Survey Instrument}

The following 17 statements are about how you feel at work. Please read each statement carefully and decide if you ever feel this way about your job. If you have never had this feeling, put a ' 0 ' (zero) in the space after the statement. If you have had this feeling, indicate how often you feel it by picking a number (from 1 to 6) that best describes how frequently you feel that way.

\begin{tabular}{|c|c|c|c|c|c|c|}
\hline & Almost never & Rarely & Sometimes & Often & Very often & Always \\
\hline 0 & 1 & 2 & 3 & 4 & 5 & 6 \\
\hline Never & $\begin{array}{l}\text { A few times a } \\
\text { year or less }\end{array}$ & $\begin{array}{l}\text { Once a month } \\
\text { or less }\end{array}$ & $\begin{array}{l}\text { A few times a } \\
\text { month }\end{array}$ & Once a week & $\begin{array}{c}\text { A few times a } \\
\text { week }\end{array}$ & Every day \\
\hline
\end{tabular}

1. At my work, I feel bursting with energy (VII)

2. I find the work that I do full of meaning and purpose (DE1)

3. Time flies when I'm working $(A B 1)$

4. At my job, I feel strong and vigorous (VI2)

5. I am enthusiastic about my job (DE2)

6. When I am working, I forget everything else around me (AB2)

7. My job inspires me (DE3)

8. When I get up in the morning, I feel like going to work (VI3)

9. I feel happy when I am working intensely $(A B 3)$

10. I am proud on the work that I do (DE4)

11. I am immersed in my work (AB4)

12. I can continue working for very long periods at a time (VI4)

13. To me, my job is challenging (DES)

14. I get carried away when I'm working (AB5)

15. At my job, I am very resilient, mentally (VI5)

16. It is difficult to detach myself from my job $(A B \sigma)$

17. At my work I always persevere, even when things do not go well (VI6) 


\section{Part III}

The following 10 statements are about how you feel at your organization. Please read each statement carefully and decide how you feel at your organization. Indicate how strongly you agree or disagree with the statement by selecting a number (from 1 to 5) that best describes how you feel.

\begin{tabular}{ccccc}
\hline 1 & 2 & 3 & 4 & 5 \\
$\begin{array}{c}\text { Strongly } \\
\text { Agree }\end{array}$ & Agree & Undecided & Disagree & $\begin{array}{c}\text { Strongly } \\
\text { Disagree }\end{array}$ \\
\hline
\end{tabular}

18. I count around here $(O B 1)$

19. I am taken seriously (OB2)

20. I am important $(O B 3)$

21. I am trusted (OB4)

22. There is faith in me $(O B 5)$

23. I can make a difference $(O B 6)$

24. I am valuable (OB7)

25. I am helpful (OB8)

26. I am efficient $(O B 9)$

27. I am cooperative (OB10)

Please Continue to Next Page 


\section{Part IV}

Listed below is a series of statements that represent feelings that individuals might have about the company or organization for which they work. With respect to your own feelings about the particular organization for which you are now working, please indicate the degree of your agreement or disagreement with each statement by selecting a number from 1 to 5 using the scale below.

\begin{tabular}{ccccc}
\hline 1 & 2 & 3 & 4 & 5 \\
$\begin{array}{c}\text { Strongly } \\
\text { Agree }\end{array}$ & Agree & Undecided & Disagree & $\begin{array}{c}\text { Strongly } \\
\text { Disagree }\end{array}$ \\
\hline
\end{tabular}

28. I would be very happy to spend the rest of my career with this organization $(A C l)$

29. Right now, staying with my organization is a matter of necessity as much as desire (CCI)

30. I do not feel any obligation to remain with my current employer ( $\mathrm{NCl}$ )

31. I really feel as if this organization's problems are my own (AC2)

32. It would be very hard for me to leave my organization right now, even if I wanted to (CC2)

33. Even if it were to my advantage, I do not feel it would be right to leave my organization now (NC2)

34. I do not feel a strong sense of "belonging" to my organization $(A C 3)$

35. Too much of my life would be disrupted if I decided I want to leave my organization now (CC3)

36. I would feel guilty if I left my organization now (NC3)

37. I do not feel "emotionally attached" to this organization (AC4)

38. I feel that I have too few options to consider leaving this organization (CC4)

39. This organization deserves my loyalty (NC4)

40. I do not feel like "part of the family" at my organization (AC5)

41. If I had not already put so much of myself into this organization, I might consider working elsewhere (CC5)

42. I would not leave my organization right now because I have a sense of obligation to the people in it (NC5)

43. This organization has a great deal of personal meaning for me $(A C 6)$

44. One of the few negative consequences of leaving this organization would be the scarcity of available alternatives (CC6)

45. I owe a great deal to my organization (NC6) 


\section{Part V}

Listed below are a series of fourteen questions. Please follow the directions under each section regarding your views on medication errors.

46. In your estimation, what percentage of all drug errors are reported to the Nurse Manager by the completion of an incident report?

(Please make an $\mathrm{X}$ on the line that corresponds most closely to your estimation.)

$1 \%$

$100 \%(\mathrm{MG} 1.01)$

47. The following ten statements are all possible causes of medication errors.

Please read them carefully and Rank \#1 to \#10. (\#1 most frequent and \#10 least frequent)

a. Drug errors occur when the nurse fails to check the patient's name band with the Medication Administration Record (MAR.)

(MG1.02)

b. Drug errors oceur when the physician's writing on the doctor's order form is difficult to read or illegible.

(MG1.05)

c. Drug errors occur when the medication labels/packaging are of poor quality or damaged.

(MG1.04)

d. Drug errors occur when there is confusion between two drugs with similar names.

(MG1.05)

e. Drug errors occur when the physician prescribes the wrong dose.

(MG1.06)

f. Drug errors occur when the nurse miscalculates the dose.

(MG1.07)

R. Drug errors occur when the nurse sets up or adjusts an infusion device incorrectly.

(MG1.08)

h. Drug errors occur when nurses are confused by the different types and functions of infusion devices.

(MG1.09)

i. Drug errors occur when nurses are distracted by other patients, coworkers or events on the unit.

(MG1.10)

j. Drug errors occur when nurses are tired and exhausted.

(MG1.11) 
NURSES' PERCEPTIONS ABOUT MEDICATION ERRORS:

It is not always clear to nurses whether what they view as a minor drug discrepancy should be reported as a medication error. In the following examples you are asked to indicate:
a. Whether or not a medication error occurred.
b. Whether or not the physician should be notified.
c. Whether or not an incident report should be completed.

Please answer "YES" or "NO" for each of the following statements:

48. A patient misses his midday dose of oral ampicillin because he was in X-Ray for three hours.
a. Drug Error
Yes
No (MG1.12)
b. Notify Physician
Yes
No (MG1.13)
c. Incident Report Necessary
Yes
No (MG1.14)

49. Four patients on a busy surgical unit receive their 6:00pm doses of IV antibiotics 4 hours late.
a. Drug Error
Yes
No (MG1.15)
b. Notify Physician
Yes
No (MG1.16)
c. Incident Report Necessary
Yes

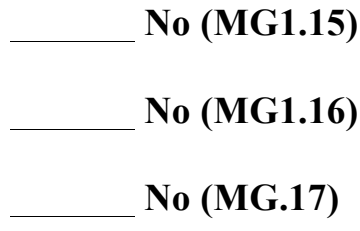

50. A patient receiving TPN feeding via an infusion pump is given $200 \mathrm{ml} / \mathrm{hr}$ instead of the correct rate of $125 \mathrm{ml} / \mathrm{hr}$ for the first three hours of the 24-hour infusion. The pump was reset to the correct rate after the change of shift at 7:00am when the oncoming nurse realized that the pump was set at the incorrect rate.
a. Drug Error
Yes
No (MG1.18)
b. Notify Physician
Yes
No (MG1.19)
c. Incident Report Necessary
Yes
No (MG1.20)

51. A patient admitted with status asthmaticus on $08 / 13$ at $2:$ am is prescribed ventolin nebulizers every four hours. The nurse omits the 6:00am dose on 08/13/97 as the patient is asleep.
a. Drug Error
Yes
No (MG1.21)
b. Notify Physician
Yes
No (MG1.22)
c. Incident Report Necessary
Yes
No (MG1.23) 
52. A physician orders percocet 1-2 tabs for post-op pain every 4 hours. At 4:00pm the patient complains of pain, requests one pill and is medicated. At 6:30pm the patient requests the second pain pill. The nurse administers the pill.
a. Drug Error
Yes
No (MG1.24)
b. Notify Physician
Yes
No (MG1.25)
c. Incident Report Necessary

Yes
Yes
No (MG1.26)

53. A patient is receiving a routine 9 am dose of digoxin everyday. Yesterday's digoxin level was 1.8 (the high side of normal). A digoxin level was drawn at 6 am today. At 9 am the nurse holds the digoxin because the lab value is not available yet.
a. Drug Error
Yes
No (MG1.27)
b. Notify Physician
Yes
No (MG1.28)
c. Incident Report Necessary
Yes
No (MG1.29)

What are your views about reporting medication errors? Please check the most appropriate response:

What are your views about reporting medication errors? Please check the most appropriate response:

54. I am usually sure what constitutes a medication error Yes No (MCi.3o)

55. I am usually sure when a medication error should be reported using an incident report

Yes

No (MGi.3)

56. Some medication errors are not reported because Yes No (MC1.32) nurses are afraid of the reaction they will receive from the Nurse Manager.

57. Some medication errors are not reported because nurses are afraid of the reaction they will receive from their coworkers.

58. Have you ever failed to report a drug error beeause Yes No (MC1.34) you did not think the error was serious to warrant reporting?

59. Have you ever failed to report a medication error because you were afraid that you might be subject to disciplinary action or even lose your job?

Yes No (Moiss)

\section{Thank you so much for taking the time to fill out this survey!}




\title{
APPENDIX C
}

\section{Instrument Permissions}

\section{Utrecht Work Engagement Scale (UWES)}

\author{
From UWES Publication:
}

Schaufeli, W. B., \& Bakker, A. B. (2003). UWES-Utrecht work engagement scale: test manual. Unpublished Manuscript: Department of Psychology, Utrecht University.

(C) Schaufeli \& Bakker (2003). The Utrecht Work Engagement Scale is free for use for non-commercial scientific research. Commercial and/or non-scientific use is prohibited, unless previous written permission is granted by the authors

\section{Organization-Based Self-Esteem (OBSE)}

\author{
From PsycTESTS Publication:
}

CPsycTESTS ${ }^{\circ}$

\section{Organization-Based Self-Esteem}

PsycTESTS Citation:

Pierce, J. L., Gardner, D. G., Cummings, L. L., \& Dunham, R. B. (1989). Organization-Based Self-Esteem [Database record]. Retrieved from PsycTESTS. doi: 10.1037/t24110-000

Test Shown: Full

Test Format:

Respondents use a 5-point Likert scale to rate the extent to which they agreed or disagreed with items.

Source:

Supplied by author.

Original Publication:

Pierce, Jon L., Gardner, Donald G., Cummings, Larry L., \& Dunham, Randall B. (1989). Organization-based self-esteem: Construct definition, measurement, and validation. Academy of Management Journal, Vol 32(3), 622-648. doi: $10.2307 / 256437$

Permissions:

Test content may be reproduced and used for non-commercial research and educational purposes without seeking written permission. Distribution must be controlled, meaning only to the participants engaged in the research or enrolled in the educational activity. Any other type of reproduction or distribution of test content is not authorized without written permission from the author and publisher. 


\title{
APPENDIX C - Continued
}

\author{
Instrument Permissions
}

\section{Three Component Model of Commitment (TCM)}

From TCM Employee Commitment Survey Academic Users Guide:

Meyer, J. P., \& Allen, N. J. (2004). TCM employee commitment survey academic users guide 2004. London, Ontario, Canada: The University of Western Ontario, Department of Psychology.

\section{TCM Employee Commitment Survey Academic Users Guide}

\begin{abstract}
Based on the Three-Component Model (TCM) of commitment (Meyer \& Allen, 1991; 1997), the TCM Employee Commitment Survey measures three forms of employee commitment to an organization: desire-based (affective commitment), obligation-based (normative commitment) and cost-based (continuance commitment). The survey includes three well-validated scales, the Affective Commitment Scale (ACS), the Normative Commitment Scale (NCS) and the Continuance Commitment Scale (CCS). Each is scored separately and can be used to identify the "commitment profile" of employees within an organization.

This academic version of the TCM Employee Commitment Survey was prepared for those who intend to use the commitment scales for academic research purposes. Original and revised versions of the scales are provided in Appendix A. This guide provides background information on the development of the commitment scales and addresses general issues pertaining to their use. Appendix B provides a list of references that you can consult for more information.
\end{abstract}

\section{Modified Gladstone 2005 - Nurse Perception of Medication Errors}

Consent for use provided by Dr. Mayo on August 6, 2015 via email 
APPENDIX D

\section{Literature Review Table}

Organization-Based Self-Esteem/Organizational Commitment

\begin{tabular}{|c|c|c|c|c|}
\hline Author/Title & $\begin{array}{c}\text { Setting/ } \\
\text { Participants }\end{array}$ & Methodology & $\begin{array}{c}\text { Instruments/ } \\
\text { Psychometrics }\end{array}$ & Findings \\
\hline $\begin{array}{l}\text { Chen et al. } \\
\text { (2015) } \\
\text { Organization- } \\
\text { based self-esteem } \\
\text { mediates the } \\
\text { effects of social } \\
\text { support and job } \\
\text { satisfaction on } \\
\text { intention to stay } \\
\text { in nurses. }\end{array}$ & $\begin{array}{l}791 \text { Registered } \\
\text { Nurses in a } \\
\text { medical center in } \\
\text { Northern Taiwan }\end{array}$ & $\begin{array}{l}\text { Quantitative } \\
\text { (Survey) } \\
\text { Cross-sectional, } \\
\text { correlational } \\
\text { study }\end{array}$ & $\begin{array}{l}\text { OBSE Scale } \\
\text { Promotion } \\
\text { Opportunity } \\
\text { Scale (Chu, } \\
\text { 2001) } \\
\text { Social Support } \\
\text { Scale (Lin \& } \\
\text { Shiao, 2005) } \\
\text { Work Stress } \\
\text { Scale (See et al., } \\
\text { 2007) } \\
\text { Job Satisfaction } \\
\text { Scale (Wang et } \\
\text { al., 2006) } \\
\text { Intention to Stay } \\
\text { in Nursing Scale } \\
\text { (Hill, 2011) } \\
\\
\text { Data Analysis: } \\
\text { SPSS for } \\
\text { Descriptive } \\
\text { analysis \& } \\
\text { Smart PLS } \\
\text { Software for } \\
\text { Structural } \\
\text { Equation } \\
\text { Modeling }\end{array}$ & $\begin{array}{l}\text { *OBSE along with } \\
\text { social support, } \\
\text { work stress, job } \\
\text { satisfaction } \\
\text { affected intention } \\
\text { to stay } \\
\text { *OBSE has a } \\
\text { mediating effect } \\
\text { on social support } \\
\text { and job } \\
\text { satisfaction on } \\
\text { intention to stay } \\
\text { - meaning, } \\
\text { intention to stay } \\
\text { increased with } \\
\text { enhanced OBSE } \\
\text { and perception of } \\
\text { social support }\end{array}$ \\
\hline $\begin{array}{l}\text { Carson, Carson, } \\
\text { Lanford, \& Roe } \\
\text { (1997) } \\
\text { The effects of } \\
\text { organization- } \\
\text { based self-esteem } \\
\text { on workplace } \\
\text { outcomes: An } \\
\text { examination of } \\
\text { emergency } \\
\text { medical } \\
\text { technicians. }\end{array}$ & $\begin{array}{l}46 \text { Emergency } \\
\text { Medical } \\
\text { Technicians } \\
\text { (Non-nursing) in } \\
\text { Southeastern } \\
\text { United States }\end{array}$ & $\begin{array}{l}\text { Quantitative } \\
\text { (Survey) }\end{array}$ & $\begin{array}{l}\text { OBSE Scale } \\
\text { Career } \\
\text { Commitment } \\
\text { Measure (Carson } \\
\text { \& Bedeian, } \\
\text { 1994) } \\
\text { Job Satisfaction } \\
\text { Index (Brayfield } \\
\text { \& Rothe, 1951) } \\
\text { Career } \\
\text { Withdrawal } \\
\text { Survey (Mobley } \\
\text { et al, 1982) }\end{array}$ & $\begin{array}{l}\text { *OBSE plays a } \\
\text { vital role in } \\
\text { career } \\
\text { commitment of } \\
\text { EMTs in the study } \\
\text { *Participants high } \\
\text { in OBSE had } \\
\text { better } \\
\text { interactions with } \\
\text { consumers than } \\
\text { those with low } \\
\text { OBSE } \\
\text { *Role clarification } \\
\text { may help }\end{array}$ \\
\hline
\end{tabular}




\begin{tabular}{|c|c|c|c|c|}
\hline Author/Title & $\begin{array}{c}\text { Setting/ } \\
\text { Participants }\end{array}$ & Methodology & $\begin{array}{l}\text { Instruments/ } \\
\text { Psychometrics }\end{array}$ & Findings \\
\hline & & & $\begin{array}{l}\text { Import of Quality } \\
\text { Scale (Garvin, } \\
\text { 1988) } \\
\text { Data Analysis: } \\
\text { One-Way } \\
\text { ANOVAs } \\
\text { Principal } \\
\text { Component } \\
\text { Analysis }\end{array}$ & $\begin{array}{l}\text { organizations } \\
\text { boost OBSE in } \\
\text { their employee } \\
\text { population }\end{array}$ \\
\hline $\begin{array}{l}\text { Gardner, D. G., } \\
\text { van Dyne, L., \& } \\
\text { Pierce, J. L. } \\
\text { (2004) } \\
\text { The effects of pay } \\
\text { level on } \\
\text { organization- } \\
\text { based self-esteem } \\
\text { and performance: } \\
\text { A field study. }\end{array}$ & $\begin{array}{l}\text { 91 Employees } \\
\text { (Non-nursing) } \\
\text { Midwest United } \\
\text { States }\end{array}$ & $\begin{array}{l}\text { Quantitative } \\
\text { (Survey and } \\
\text { other data } \\
\text { collected) } \\
\text { Longitudinal - } \\
12 \text { months } \\
\text { (Time 1) Data } \\
\text { collected on pay } \\
\text { level - yearly } \\
\text { compensation } \\
\text { for all 91 } \\
\text { participants } \\
\text { Three months } \\
\text { later (Time 2) } \\
\text { self-report } \\
\text { survey } \\
\text { distributed } \\
9 \text { months (after } \\
\text { time 2) } \\
\text { performance } \\
\text { appraisal data } \\
\text { collected for } \\
\text { past 12 months } \\
\text { (Time 3) - 62 } \\
\text { participants } \\
\text { remain }\end{array}$ & $\begin{array}{l}\text { OBSE Scale } \\
\begin{array}{l}\text { Pay Level data as } \\
\text { reported from } \\
\text { organization }\end{array} \\
\text { Performance } \\
\text { Scale developed } \\
\text { by organization } \\
\text { Data Analysis: } \\
\text { Hierarchical } \\
\text { regression } \\
\text { analysis }\end{array}$ & $\begin{array}{l}\text { *Study interested } \\
\text { in finding out } \\
\text { how pay level } \\
\text { influences/affects } \\
\text { employee } \\
\text { performance } \\
\text { *OBSE can help } \\
\text { determine how } \\
\text { individual } \\
\text { differences may } \\
\text { link pay and } \\
\text { performance } \\
\text { *Pay level is } \\
\text { significantly } \\
\text { related to OBSE } \\
\text { and performance }\end{array}$ \\
\hline $\begin{array}{l}\text { Gardner, D. G., } \\
\text { \& Pierce, J. L. } \\
\text { (2011) } \\
\text { A question of } \\
\text { false self-esteem: } \\
\text { Organization- } \\
\text { based self-esteem } \\
\text { and narcissism in } \\
\text { organizational } \\
\text { contexts. }\end{array}$ & $\begin{array}{l}\text { 236 Employees } \\
\text { (Non-nursing) } \\
\text { United States }\end{array}$ & $\begin{array}{l}\text { Quantitative } \\
\text { (Survey) }\end{array}$ & $\begin{array}{l}\text { Narcissism } \\
\text { Personality } \\
\text { Inventory } \\
\text { (Raskin \& Terry, } \\
\text { 1988) } \\
\text { OBSE Survey } \\
\text { Job Satisfaction } \\
\text { Scale (Brayfield } \\
\text { \& Rothe, 1951) }\end{array}$ & $\begin{array}{l}\text { *OBSE and } \\
\text { Narcissism are } \\
\text { very different } \\
\text { constructs } \\
\text { *First study to } \\
\text { look at } \\
\text { relationship of } \\
\text { narcissism and } \\
\text { OBSE } \\
\text { *Narcissism }\end{array}$ \\
\hline
\end{tabular}




\begin{tabular}{|c|c|c|c|c|}
\hline Author/Title & $\begin{array}{c}\text { Setting/ } \\
\text { Participants }\end{array}$ & Methodology & $\begin{array}{l}\text { Instruments/ } \\
\text { Psychometrics }\end{array}$ & Findings \\
\hline & & & $\begin{array}{l}\text { Job Involvement } \\
\text { Scale (Lodhal \& } \\
\text { Kejner, 1965). } \\
\text { Intrinsic } \\
\text { Motivation Scale } \\
\text { (Hackman \& } \\
\text { Oldham, 1980) }\end{array}$ & $\begin{array}{l}\text { correlated } \\
\text { positively with } \\
\text { job satisfaction, } \\
\text { job involvement } \\
\text { and intrinsic } \\
\text { motivation. } \\
{ }^{*} \text { Organizations } \\
\text { need to be careful } \\
\text { when delivering } \\
\text { negative feedback } \\
\text { to narcissistic } \\
\text { employees - be } \\
\text { sure to provide } \\
\text { concrete evidence } \\
\text { to support } \\
\text { statements }\end{array}$ \\
\hline $\begin{array}{l}\text { Hui, C., \& Lee, } \\
\text { C. (2000) } \\
\text { Moderating } \\
\text { effects of } \\
\text { organization- } \\
\text { based self-esteem } \\
\text { on organizational } \\
\text { uncertainty: } \\
\text { Employee } \\
\text { response } \\
\text { relationships. }\end{array}$ & $\begin{array}{l}378 \text { Employees } \\
\text { (Non-nursing) } \\
\text { Hong Kong }\end{array}$ & $\begin{array}{l}\text { Quantitative } \\
\text { (Survey) } \\
\text { Randomized } \\
\text { cross-sectional } \\
\text { study }\end{array}$ & $\begin{array}{l}\text { OBSE Survey } \\
\text { Intrinsic Job } \\
\text { Motivation Scale } \\
\text { (Warr, Cook \& } \\
\text { Wall, 1979) } \\
\text { Organizational } \\
\text { Commitment } \\
\text { Scale (Mowday } \\
\text { et al., 1979) } \\
\text { Job Insecurity } \\
\text { Scale } \\
\text { (Caplan et al., } \\
\text { 1975) } \\
\text { Organizational } \\
\text { Change Scale } \\
\text { (Ashford et al., } \\
\text { 1989) } \\
\text { Control } \\
\text { Measures: } \\
\text { Age, Gender and } \\
\text { Tenure in } \\
\text { Organization } \\
\text { Data Analysis: } \\
\text { LISREL package } \\
\text { Confirmatory } \\
\text { Factor Analysis }\end{array}$ & $\begin{array}{l}\text { *Results confirm } \\
\text { OBSE as an } \\
\text { "important } \\
\text { individual-level" } \\
\text { moderator of } \\
\text { relationships. } \\
\text { * OBSE may assist } \\
\text { management in } \\
\text { managing } \\
\text { employees } \\
\text { through } \\
\text { organizational } \\
\text { changes - } \\
\text { especially when } \\
\text { job insecurity is } \\
\text { evident }\end{array}$ \\
\hline $\begin{array}{l}\text { McAllister, D. J., } \\
\text { \& Bigley, G. A. } \\
\text { (2002) } \\
\text { Work context and }\end{array}$ & $\begin{array}{l}186 \text { Students } \\
\text { and alumni from } \\
\text { a Southern } \\
\text { California }\end{array}$ & $\begin{array}{l}\text { Quantitative } \\
\text { (Survey) }\end{array}$ & $\begin{array}{l}\text { OBSE Survey } \\
\text { Organizational } \\
\text { Care Survey }\end{array}$ & $\begin{array}{l}* \text { Organizational } \\
\text { care is an } \\
\text { important factor } \\
\text { to consider when }\end{array}$ \\
\hline
\end{tabular}




\begin{tabular}{|c|c|c|c|c|}
\hline Author/Title & $\begin{array}{c}\text { Setting/ } \\
\text { Participants }\end{array}$ & Methodology & $\begin{array}{l}\text { Instruments/ } \\
\text { Psychometrics }\end{array}$ & Findings \\
\hline $\begin{array}{l}\text { the definition of } \\
\text { self: How } \\
\text { organizational } \\
\text { care influences } \\
\text { organization- } \\
\text { based self-esteem. }\end{array}$ & $\begin{array}{l}\text { University } \\
\text { executive MBA } \\
\text { program } \\
\text { participated } \\
\text { along with } \\
\text { members of their } \\
\text { respective } \\
\text { organizations. }\end{array}$ & & $\begin{array}{l}\text { (Eisnberger et al, } \\
\text { 1986) } \\
\text { Reputational } \\
\text { Effectiveness } \\
\text { scale (Tsui, } \\
\text { 1984) and 1- } \\
\text { item from } \\
\text { McAllister } \\
\text { (1995) } \\
\text { Data Analysis: } \\
\text { EQS Program } \\
\text { Structural } \\
\text { Equation } \\
\text { Modeling }\end{array}$ & $\begin{array}{l}\text { identifying OBSE } \\
\text { *Organizational } \\
\text { values and } \\
\text { organizations } \\
\text { acting in the } \\
\text { employees' best } \\
\text { interests } \\
\text { reported having } \\
\text { employees with } \\
\text { higher OBSE } \\
\text { levels. } \\
\text { *Relationship } \\
\text { between work } \\
\text { context and self- } \\
\text { esteem is indirect } \\
\text { - mediated by } \\
\text { perceptions of job } \\
\text { authority fairness } \\
\text { and } \\
\text { organizational } \\
\text { fairness }\end{array}$ \\
\hline $\begin{array}{l}\text { Sekiguchi, T., } \\
\text { Burton, J. P., \& } \\
\text { Sablynski, C. J. } \\
\text { (2008) } \\
\text { The role of job } \\
\text { embeddedness on } \\
\text { employee } \\
\text { performance: the } \\
\text { interactive effects } \\
\text { with leader- } \\
\text { member exchange } \\
\text { and organization- } \\
\text { based self-esteem. }\end{array}$ & $\begin{array}{l}367 \text { Employees } \\
\text { (Non-nursing) } \\
41 \text { Supervisors } \\
\text { (Non-nursing) } \\
2 \text { Organizations }\end{array}$ & $\begin{array}{l}\text { Quantitative } \\
\text { (Survey) }\end{array}$ & $\begin{array}{l}\text { Task } \\
\text { Performance } \\
\text { Survey (Williams } \\
\text { \& Anderson, } \\
\text { 1991) } \\
\text { Organizational } \\
\text { Citizenship } \\
\text { Behavior Scale } \\
\text { (Podsakoff \& } \\
\text { Mackenzie, } \\
\text { 1994) } \\
\text { Leader-Member } \\
\text { Exchange (LMX) } \\
\text { Scale } \\
\text { (Graen, Novak \& } \\
\text { Sommerkamp, } \\
\text { 1982) } \\
\text { Job } \\
\text { Embeddedness } \\
\text { Scale (Lee et al., } \\
\text { 2004) } \\
\text { Data Analysis: } \\
\text { Factor Analysis - } \\
\text { principal axis } \\
\text { factoring with } \\
\text { varimax rotation }\end{array}$ & $\begin{array}{l}\text { *Study focused on } \\
\text { job } \\
\text { embeddedness } \\
\text { pertaining to } \\
\text { leader-member } \\
\text { exchange, OBSE, } \\
\text { organizational } \\
\text { citizenship } \\
\text { behaviors and } \\
\text { task performance. } \\
\text { *"The role of } \\
\text { OBSE becomes } \\
\text { more salient } \\
\text { when employees } \\
\text { are highly } \\
\text { embedded in } \\
\text { their job and } \\
\text { organization, } \\
\text { which then } \\
\text { influences } \\
\text { employee } \\
\text { performance } \\
\text { either directly or } \\
\text { indirectly by } \\
\text { interacting with } \\
\text { LMX."(p.785) }\end{array}$ \\
\hline
\end{tabular}




\begin{tabular}{|c|c|c|c|c|}
\hline Author/Title & $\begin{array}{c}\text { Setting/ } \\
\text { Participants }\end{array}$ & Methodology & $\begin{array}{l}\text { Instruments/ } \\
\text { Psychometrics }\end{array}$ & Findings \\
\hline $\begin{array}{l}\text { Panaccio, A., \& } \\
\text { Vandenberghe, } \\
\text { C. (2011) } \\
\text { The relationships } \\
\text { of role clarity and } \\
\text { organization- } \\
\text { based self-esteem } \\
\text { to commitment to } \\
\text { supervisors and } \\
\text { organizations and } \\
\text { turnover } \\
\text { intentions. }\end{array}$ & $\begin{array}{l}311 \text { Employees } \\
\text { (Non-nursing) } \\
\text { Canada/France }\end{array}$ & $\begin{array}{l}\text { Quantitative } \\
\text { (Survey) }\end{array}$ & $\begin{array}{l}\text { Organizational } \\
\text { Commitment - } \\
\text { Meyer et al. } \\
\text { (1993) } \\
\text { OBSE Survey } \\
\text { Commitment to } \\
\text { Supervisor } \\
\text { Instrument - } \\
\text { Stinglhamber et } \\
\text { al (2002) } \\
\text { Role Clarity } \\
\text { Instrument - } \\
\text { Rizzo et al. } \\
\text { (1970) } \\
\text { Data Analysis: } \\
\text { LISREL: } \\
\text { Confirmatory } \\
\text { Factor Analysis }\end{array}$ & $\begin{array}{l}\text { *Study found that } \\
\text { high OBSE is } \\
\text { related to } \\
\text { reduced turnover } \\
{ }^{*} \text { OBSE } \\
\text { contributes to } \\
\text { Affective } \\
\text { Commitment by } \\
\text { employees }\end{array}$ \\
\hline $\begin{array}{l}\text { Lapointe, É., } \\
\text { Vandenberghe, } \\
\text { C., \& Panaccio, } \\
\text { A. (2011) } \\
\text { Organizational } \\
\text { commitment, } \\
\text { organization- } \\
\text { based self-esteem, } \\
\text { emotional } \\
\text { exhaustion and } \\
\text { turnover: A } \\
\text { conservation of } \\
\text { resources } \\
\text { perspective. }\end{array}$ & $\begin{array}{l}260 \text { Employees } \\
\text { (Non-nursing) } \\
\text { Canada }\end{array}$ & $\begin{array}{l}\text { Quantitative } \\
\text { (Survey) } \\
\text { Longitudinal } \\
\text { study of work } \\
\text { attitudes: } \\
\\
\text { Test-Retest } \\
\text { Time 1/Time } 2 \\
1 \text { year apart }\end{array}$ & $\begin{array}{l}\text { Organizational } \\
\text { Commitment - } \\
\text { Meyer et al. } \\
\text { (1993) } \\
\text { OBSE Survey } \\
\text { Emotional } \\
\text { Exhaustion - } \\
\text { Maslach Burnout } \\
\text { Inventory - } \\
\text { general survey } \\
\\
\text { Data Analysis } \\
\text { LISREL: } \\
\text { Confirmatory } \\
\text { Factor Analysis }\end{array}$ & $\begin{array}{l}\text { *Relationship } \\
\text { between affective, } \\
\text { normative and } \\
\text { continuance } \\
\text { commitment to } \\
\text { emotional } \\
\text { exhaustion using } \\
\text { conservation of } \\
\text { resources theory: } \\
\text {-Lack of } \\
\text { alternatives and } \\
\text { normative } \\
\text { commitment was } \\
\text { related to } \\
\text { increased } \\
\text { emotional } \\
\text { exhaustion over } \\
\text { time } \\
\text {-Lack of } \\
\text { alternatives was } \\
\text { exacerbated by } \\
\text { an individual's } \\
\text { OBSE }\end{array}$ \\
\hline
\end{tabular}

\begin{tabular}{|l|l|l|l|l|}
\hline $\begin{array}{l}\text { De Gieter, S., } \\
\text { Hofmans, J., \& } \\
\text { Pepermans, R. } \\
\text { (2011) Revisiting } \\
\text { the impact of job }\end{array}$ & $\begin{array}{l}\text { 287 Nurses in a } \\
\text { variety of } \\
\text { hospitals in }\end{array}$ & $\begin{array}{l}\text { Quantitative } \\
\text { (Survey) }\end{array}$ & $\begin{array}{l}\text { PI-developed } \\
\text { turnover } \\
\text { intention scale }\end{array}$ & $\begin{array}{l}\text { *organizational } \\
\text { commitment and } \\
\text { job satisfaction } \\
\text { predicted nurse } \\
\text { turnover }\end{array}$ \\
\hline
\end{tabular}




\begin{tabular}{|c|c|c|c|c|}
\hline $\begin{array}{l}\text { satisfaction and } \\
\text { organizational } \\
\text { commitment on } \\
\text { nurse turnover } \\
\text { intention: An } \\
\text { individual } \\
\text { differences } \\
\text { analysis. }\end{array}$ & & & $\begin{array}{l}\text { Commitment } \\
\text { Scale by Meyer et } \\
\text { al. (1993) } \\
\text { Job Satisfaction } \\
\text { Scale by } \\
\text { Hackman and } \\
\text { Oldham (1976) } \\
\text { Data analysis: } \\
\text { Mixed regression } \\
\text { models, t-tests, } \\
\text { chi square tests }\end{array}$ & $\begin{array}{l}\text { intention } \\
\text { *younger nurses } \\
\text { and those with } \\
\text { less tenure had } \\
\text { greater intentions } \\
\text { to leave }\end{array}$ \\
\hline $\begin{array}{l}\text { Carter, M. R., \& } \\
\text { Tourangeau, A. } \\
\text { E. (2012) } \\
\text { Staying in } \\
\text { nursing: what } \\
\text { factors determine } \\
\text { whether nurses } \\
\text { intend to remain } \\
\text { employed? }\end{array}$ & $\begin{array}{l}17,707 \text { nurses } \\
\text { working in } 390 \\
\text { NHS } \\
\text { organizations in } \\
\text { the United } \\
\text { Kingdom }\end{array}$ & $\begin{array}{l}\text { Quantitative } \\
\text { (Survey) }\end{array}$ & $\begin{array}{l}\text { NHS National } \\
\text { Staff Survey } \\
\text { SPSS - } \\
\text { Descriptive } \\
\text { Statistics and } \\
\text { Cronbach's alpha } \\
\text { M-Plus - } \\
\text { Structural } \\
\text { Equation } \\
\text { Modeling (within } \\
\text { and between) }\end{array}$ & $\begin{array}{l}\text { *Psychologically } \\
\text { engaged nurses } \\
\text { are less likely to } \\
\text { leave their } \\
\text { current job } \\
\text { *small } \\
\text { relationship } \\
\text { between nursing } \\
\text { relationship with } \\
\text { colleagues and } \\
\text { patients and } \\
\text { nurse turnover } \\
\text { intentions } \\
\text { *Intent to leave } \\
\text { influenced by } \\
\text { opportunities for } \\
\text { growth, work } \\
\text { pressures and } \\
\text { work-life balance }\end{array}$ \\
\hline \multicolumn{5}{|c|}{ Work Engagement } \\
\hline Author/Title & $\begin{array}{r}\text { Setting/ } \\
\text { Participants }\end{array}$ & Methodology & $\begin{array}{l}\text { Instruments/ } \\
\text { Psychometrics }\end{array}$ & Findings \\
\hline $\begin{array}{l}\text { Laschinger, H. } \\
\text { K., Wilk, P., } \\
\text { Cho, J., \& } \\
\text { Greco, P. } \\
\text { (2009) } \\
\text { Empowerment, } \\
\text { engagement } \\
\text { and perceived } \\
\text { effectiveness in } \\
\text { nursing work } \\
\text { environments: } \\
\text { does experience } \\
\text { matter? }\end{array}$ & $\begin{array}{l}\text { Combination of } \\
2 \text { Studies in } \\
\text { Canada } \\
\text { Study 1: } 282 \\
\text { New Graduate } \\
\text { RNs identified } \\
\text { with less than } \\
3 \text { years of } \\
\text { experience on } \\
\text { the license } \\
\text { renewal in } \\
\text { Canada were } \\
\text { randomly } \\
\text { selected. } \\
\text { Study 2: } \\
\text { Representative }\end{array}$ & $\begin{array}{l}\text { Quantitative } \\
\text { (Survey) } \\
\text { Both groups of nurses } \\
\text { were combined to } \\
\text { reflect a sample size of } \\
185\end{array}$ & $\begin{array}{l}\text { Conditions of } \\
\text { Work } \\
\text { Effectiveness - } \\
\text { II } \\
\text { Utrecht Work } \\
\text { Engagement } \\
\text { Scale } \\
\text { Global } \\
\text { Empowerment } \\
\text { Scale } \\
\\
\text { Data analyzed } \\
\text { through } \\
\text { Structural } \\
\text { Equation }\end{array}$ & $\begin{array}{l}\text { Work } \\
\text { engagement } \\
\text { can be linked to } \\
\text { workplace } \\
\text { empowerment. } \\
\text { Work } \\
\text { engagement } \\
\text { and } \\
\text { empowerment } \\
\text { has an effect on } \\
\text { work } \\
\text { effectiveness. }\end{array}$ \\
\hline
\end{tabular}




\begin{tabular}{|c|c|c|c|c|}
\hline & $\begin{array}{l}\text { sample of acute } \\
\text { care RNs in } \\
\text { Canada } \\
(n=311)\end{array}$ & & Modeling & \\
\hline $\begin{array}{l}\text { Lawrence, L. } \\
\text { A. (2011) } \\
\text { Work } \\
\text { engagement, } \\
\text { moral distress, } \\
\text { education level, } \\
\text { and critical } \\
\text { reflective } \\
\text { practice in } \\
\text { intensive care } \\
\text { nurses. }\end{array}$ & $\begin{array}{l}28 \text { ICU RNs in } \\
355 \text {-bed } \\
\text { hospital in the } \\
\text { Southwest } \\
\text { United States } \\
\text { (Magnet } \\
\text { facility) }\end{array}$ & $\begin{array}{l}\text { Quantitative } \\
\text { (Online Survey) } \\
\text { Non-Experimental, } \\
\text { descriptive correlational } \\
\text { study. }\end{array}$ & $\begin{array}{l}\text { Investigator- } \\
\text { designed } \\
\text { Demographic } \\
\text { survey } \\
\text { Utrecht Work } \\
\text { Engagement } \\
\text { Scale } \\
\text { Moral Distress } \\
\text { Scale } \\
\text { Critical } \\
\text { Reflective } \\
\text { Practice } \\
\text { Questionnaire }\end{array}$ & $\begin{array}{l}\text { *Positive } \\
\text { relationship } \\
\text { between } \\
\text { clinical } \\
\text { reflective } \\
\text { practice and } \\
\text { work } \\
\text { engagement } \\
\text { *Negative } \\
\text { direct } \\
\text { relationship } \\
\text { between moral } \\
\text { distress and } \\
\text { work } \\
\text { engagement } \\
\text { *Education was } \\
\text { positively } \\
\text { correlated to } \\
\text { clinical } \\
\text { reflective } \\
\text { practice }\end{array}$ \\
\hline $\begin{array}{l}\text { Rivera, R. R., } \\
\text { Fitzpatrick, J. } \\
\text { J., \& Boyle, S. } \\
\text { M. (2011) } \\
\text { Closing the RN } \\
\text { engagement } \\
\text { gap: which } \\
\text { drivers of } \\
\text { engagement } \\
\text { matter? }\end{array}$ & $\begin{array}{l}510 \text { RNs from } \\
\text { large urban } \\
\text { hospital on the } \\
\text { East Coast of } \\
\text { the USA. }\end{array}$ & 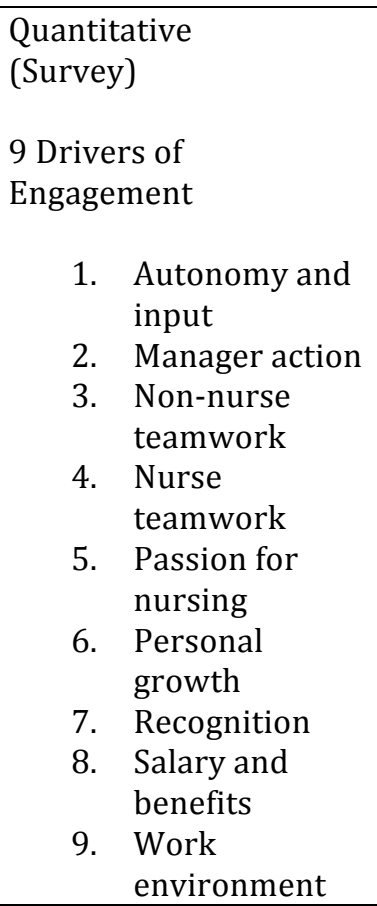 & $\begin{array}{l}\text { Nurse } \\
\text { Engagement } \\
\text { Survey } \\
\text { (Advisory } \\
\text { Board) } \\
\text { Distributed } \\
\text { online } \\
\text { Data Analysis: } \\
\text { *Pearson R } \\
\text { *Chi Squared } \\
\text { *Logistic } \\
\text { Regression }\end{array}$ & $\begin{array}{l}\text { *Drivers of } \\
\text { engagement (= } \\
\text { 9) was } \\
\text { significantly } \\
\text { positively } \\
\text { correlated to } \\
\text { the } \\
\text { engagement } \\
\text { index (p<.001, } \\
2 \text {-tailed) } \\
\text { *Day shift RNs } \\
\text { more engaged } \\
\text { than other } \\
\text { shifts } \\
\text { * Sex and } \\
\text { education not } \\
\text { significant to } \\
\text { engagement }\end{array}$ \\
\hline $\begin{array}{l}\text { Simpson, M. } \\
\text { R. (2009) } \\
\text { Predictors of } \\
\text { work } \\
\text { engagement } \\
\text { among medical- }\end{array}$ & $\begin{array}{l}167 \text { Medical } \\
\text { Surgical RNs } \\
\text { working in } \\
\text { Medical/ } \\
\text { Surgical units } \\
\text { within } 6\end{array}$ & $\begin{array}{l}\text { Quantitative } \\
\text { (Survey) } \\
\text { Descriptive, cross- } \\
\text { sectional study }\end{array}$ & $\begin{array}{l}\text { Utrecht Work } \\
\text { Engagement } \\
\text { Scale } \\
\text { Turnover } \\
\text { Cognitions }\end{array}$ & $\begin{array}{l}* \text { While nurses } \\
\text { are not actively } \\
\text { looking for } \\
\text { other jobs, } \\
\text { many think } \\
\text { about quitting. }\end{array}$ \\
\hline
\end{tabular}




\begin{tabular}{|c|c|c|c|c|}
\hline $\begin{array}{l}\text { surgical } \\
\text { registered } \\
\text { nurses }\end{array}$ & $\begin{array}{l}\text { hospitals in the } \\
\text { United States }\end{array}$ & $\begin{array}{l}\text { Relationship between } \\
\text { job satisfaction, } \\
\text { turnover cognitions, job } \\
\text { search behavior and } \\
\text { nurse demographics on } \\
\text { work engagement } \\
\text { Uses Mobley's Model of } \\
\text { Turnover as study } \\
\text { model }\end{array}$ & $\begin{array}{l}\text { Scale } \\
\text { IWS-R Scale } \\
\text { (Stamps, 1997) } \\
\text { Job Search } \\
\text { Behavior Index } \\
\text { Investigator- } \\
\text { designed } \\
\text { demographic } \\
\text { questionnaire } \\
\text { *Correlation } \\
\text { and Regression } \\
\text { analysis } \\
\text { conducted }\end{array}$ & $\begin{array}{l}\text { *Nurses are } \\
\text { least satisfied } \\
\text { with their pay } \\
\text { followed by } \\
\text { task } \\
\text { requirements } \\
\text { and hospital } \\
\text { policies. } \\
\text { *Overall, } \\
\text { nurses are } \\
\text { somewhat } \\
\text { satisfied with } \\
\text { their job and } \\
\text { have moderate } \\
\text { levels of work } \\
\text { engagement. }\end{array}$ \\
\hline $\begin{array}{l}\text { Abdelhadi, N. } \\
\text { \& Drach- } \\
\text { Zahavy, A. } \\
\text { (2012) } \\
\text { Promoting } \\
\text { patient care: } \\
\text { work } \\
\text { engagement as } \\
\text { a mediator } \\
\text { between ward } \\
\text { service climate } \\
\text { and patient- } \\
\text { centered care. }\end{array}$ & $\begin{array}{l}158 \text { Nurses } \\
\text { working in } 40 \\
\text { wards of } \\
\text { retirement } \\
\text { homes in } \\
\text { northern Israel }\end{array}$ & $\begin{array}{l}\text { Mixed Methods } \\
\text { Quantitative } \\
\text { (questionnaires) } \\
\text { Structured Observations } \\
\text { (Nested, cross sectional } \\
\text { research design) }\end{array}$ & $\begin{array}{l}\text { Global Service } \\
\text { Climate Scale } \\
\text { Work } \\
\text { Engagement } \\
\text { Scale (Salanova } \\
\text { \& Agut, 2005). } \\
\text { Structured } \\
\text { Observations: } \\
3 \text { Patient } \\
\text { Centered Care } \\
\text { (PCC) } \\
\text { observations } \\
\text { were recorded } \\
\text { by trained (10 } \\
\text { hours) } \\
\text { graduate } \\
\text { students } \\
\text { (nurses by } \\
\text { profession) } \\
\text { 9-item } \\
\text { structured } \\
\text { observation } \\
\text { sheet (Likert } \\
\text { scale) used to } \\
\text { rate PCC }\end{array}$ & $\begin{array}{l}\text { *Goal of Study: } \\
\text { Identify the } \\
\text { relationship } \\
\text { between } \\
\text { patient- } \\
\text { centered care, } \\
\text { service climate } \\
\text { and work } \\
\text { engagement } \\
\text { *Work } \\
\text { engagement is } \\
\text { a mediator in } \\
\text { the } \\
\text { relationship } \\
\text { between } \\
\text { service climate } \\
\text { and patient } \\
\text { centered care } \\
\text { *Nurses who } \\
\text { experience } \\
\text { higher levels of } \\
\text { work } \\
\text { engagement } \\
\text { provide greater } \\
\text { patient } \\
\text { centered care }\end{array}$ \\
\hline $\begin{array}{l}\text { Tillott, S., } \\
\text { Walsh, K., \& } \\
\text { Moxham, L. } \\
\text { (2013) } \\
\text { Encouraging } \\
\text { engagement at } \\
\text { work to } \\
\text { improve } \\
\text { retention: Sarah }\end{array}$ & $\begin{array}{l}\text { Exploratory } \\
\text { paper to reflect } \\
\text { on factors that } \\
\text { impact } \\
\text { workplace } \\
\text { culture }\end{array}$ & $\begin{array}{l}\text { Exploratory Paper } \\
\text { Review of concepts such } \\
\text { as empowerment, } \\
\text { engagement and } \\
\text { satisfaction in the } \\
\text { workplace. }\end{array}$ & None & $\begin{array}{l}\text { Key Findings: } \\
\text { *Workplace } \\
\text { culture is } \\
\text { linked to staff } \\
\text { well-being and } \\
\text { commitment } \\
\text { *Introduces } \\
\text { reader to }\end{array}$ \\
\hline
\end{tabular}




\begin{tabular}{|c|c|c|c|c|}
\hline $\begin{array}{l}\text { Tillott and } \\
\text { colleagues } \\
\text { explore how a } \\
\text { social } \\
\text { interaction tool } \\
\text { can help } \\
\text { managers } \\
\text { recruit and } \\
\text { retain staff, and } \\
\text { boost patient } \\
\text { care. }\end{array}$ & & & & $\begin{array}{l}\begin{array}{l}\text { SCARF } \\
\text { framework }\end{array} \\
\text { S=Status } \\
\text { C=Certainty } \\
\text { A=Autonomy } \\
\text { R=Relatedness } \\
\mathrm{F}=\text { Fairness } \\
\text { *The SCARF } \\
\text { framework } \\
\text { enables } \\
\text { collaborating } \\
\text { and influencing } \\
\text { of ideas to } \\
\text { others }\end{array}$ \\
\hline \multicolumn{5}{|c|}{ Nurse Perception of Medication Errors } \\
\hline Author/Title & $\begin{array}{c}\text { Setting/ } \\
\text { Participants }\end{array}$ & Methodology & $\begin{array}{l}\text { Instruments/ } \\
\text { Psychometrics }\end{array}$ & Findings \\
\hline $\begin{array}{l}\text { Gladstone, } \mathbf{J} \text {. } \\
\text { (1995) } \\
\text { Drug } \\
\text { administration } \\
\text { errors: a study into } \\
\text { the factors } \\
\text { underlying the } \\
\text { occurrence and } \\
\text { reporting of drug } \\
\text { errors in a district } \\
\text { general hospital. }\end{array}$ & $\begin{array}{l}102 \text { Trained } \\
\text { nurses randomly } \\
\text { selected from a } \\
\text { list from payroll } \\
\text { (74 full time) } \\
\text { (28 part time) } \\
17 \text { Nurse } \\
\text { Managers } \\
\text { In United } \\
\text { Kingdom }\end{array}$ & \begin{tabular}{|l} 
Questionnaires: \\
1. Nurse managers \\
2. \\
Nurse \\
Perception of \\
Medication \\
Error \\
Nurse Interviews
\end{tabular} & $\begin{array}{l}\text { Two separate } \\
\text { questionnaires } \\
\text { were distributed, } \\
\text { one for managers } \\
\text { and one for staff } \\
\text { nurses. Both } \\
\text { developed by the } \\
\text { PI. }\end{array}$ & $\begin{array}{l}\text { Many drug errors } \\
\text { are not reported. } \\
\text { The term Drug } \\
\text { Error is not clearly } \\
\text { defined. } \\
\text { Fear of discipline } \\
\text { and loss of } \\
\text { confidence due to } \\
\text { errors were } \\
\text { recurrent themes } \\
\text { in interviews. }\end{array}$ \\
\hline $\begin{array}{l}\text { Fry, M., \& } \\
\text { Dacey, C. (2007) } \\
\text { Factors } \\
\text { contributing to } \\
\text { incidents in } \\
\text { medicine } \\
\text { administration. } \\
\text { Part } 1\end{array}$ & $\begin{array}{l}\text { Literature Review } \\
\text { of factors } \\
\text { contributing to } \\
\text { medication errors } \\
\text { in the NHS system } \\
\text { in the United } \\
\text { Kingdom }\end{array}$ & $\begin{array}{l}\text { Literature review } \\
\text { revealed } 3 \\
\text { categories of } \\
\text { human error: } \\
\text { 1. Personal } \\
\text { 2. Contextual } \\
\text { 3. } \quad \text { Knowledge } \\
\quad \text { base }\end{array}$ & $\begin{array}{l}\text { Literature } \\
\text { Review of the } \\
\text { themes based on } \\
16 \text { research } \\
\text { papers relating } \\
\text { to medication } \\
\text { errors. }\end{array}$ & $\begin{array}{l}\text { Discussed human } \\
\text { error theory and } \\
\text { determined that } \\
\text { there is a little } \\
\text { evidence to show } \\
\text { that nurses know } \\
\text { the root causes } \\
\text { leading to } \\
\text { medication errors. }\end{array}$ \\
\hline $\begin{array}{l}\text { Fry, M., \& } \\
\text { Dacey, C. (2007) } \\
\text { Factors } \\
\text { contributing to } \\
\text { incidents in } \\
\text { medicine } \\
\text { administration. } \\
\text { Part } 2\end{array}$ & $\begin{array}{l}\text { Cross - section of } \\
\text { RNs in the United } \\
\text { Kingdom } \\
139 \text { participants } \\
\text { in } 15 \text { wards }\end{array}$ & $\begin{array}{l}\text { Questionnaires: } \\
\text { Demographic } \\
\text { 6-part medication } \\
\text { error } \\
\text { questionnaire }\end{array}$ & $\begin{array}{l}\text { Demographic } \\
\text { questionnaire } \\
\text { and 6-part } \\
\text { medication error } \\
\text { questionnaire } \\
\text { analyzed through } \\
\text { SPSS }\end{array}$ & $\begin{array}{l}\text { Causes of } \\
\text { medication errors } \\
\text { include: } \\
\text { *environmental } \\
\text { distractions } \\
\text { *differences in } \\
\text { training/education } \\
\text { * misleading }\end{array}$ \\
\hline
\end{tabular}




\begin{tabular}{|c|c|c|c|c|}
\hline Author/Title & $\begin{array}{c}\text { Setting/ } \\
\text { Participants }\end{array}$ & Methodology & $\begin{array}{l}\text { Instruments/ } \\
\text { Psychometrics }\end{array}$ & Findings \\
\hline & & & & $\begin{array}{l}\text { medication } \\
\text { packaging } \\
\text { *illegible } \\
\text { medication charts }\end{array}$ \\
\hline $\begin{array}{l}\text { Ulanimo, V. M., } \\
\text { O'Leary-Kelley, } \\
\text { C., \& Connolly, } \\
\text { P. M. (2007) } \\
\text { Nurses' } \\
\text { perceptions of } \\
\text { causes of } \\
\text { medication errors } \\
\text { and barriers to } \\
\text { reporting }\end{array}$ & $\begin{array}{l}\text { VA Medical Center } \\
\text { in California } \\
61 \text { medical/ } \\
\text { surgical nurses }\end{array}$ & $\begin{array}{l}\text { Descriptive study } \\
\text { with convenience } \\
\text { sample taking a } \\
\text { questionnaire } \\
\text { (27 returned } \\
\text { questionnaires) }\end{array}$ & $\begin{array}{l}\text { Modified } \\
\text { Gladstone } \\
\text { Questionnaire }\end{array}$ & $\begin{array}{l}\text { Causes of } \\
\text { Medication Errors } \\
* \text { distractions } \\
* \text { failure to check } \\
\text { arm band } \\
* \text { confusion over } \\
\text { packaging } \\
\text { * RN miscalculation } \\
\text { *MD prescribing } \\
\text { error/poor } \\
\text { handwriting }\end{array}$ \\
\hline $\begin{array}{l}\text { Maiden, J., } \\
\text { Georges, J. M., \& } \\
\text { Connelly, C. D. } \\
\text { (2011) Moral } \\
\text { distress, } \\
\text { compassion } \\
\text { fatigue, and } \\
\text { perceptions about } \\
\text { medication errors } \\
\text { in certified critical } \\
\text { care nurses. }\end{array}$ & $\begin{array}{l}205 \text { Critical Care } \\
\text { RNs around } \\
\text { United States }\end{array}$ & $\begin{array}{l}\text { Mixed Methods: } \\
\text { Quantitative } \\
\text { (Survey) } \\
\text { Qualitative } \\
\text { (Focus Group) } \\
\text { from subset of } \\
\text { quantitative } \\
\text { participants }\end{array}$ & $\begin{array}{l}\text { Demographic } \\
\text { Questionnaire } \\
\text { Moral Distress } \\
\text { Scale } \\
\text { Professional } \\
\text { Quality of Life } \\
\text { Scale } \\
\text { Medication } \\
\text { Administration } \\
\text { Error Survey } \\
\text { Focus Group (for } \\
\text { subset of } \\
\text { participants - } \\
\text { n=5) }\end{array}$ & $\begin{array}{l}\text { Significant } \\
\text { correlations } \\
\text { between moral } \\
\text { distress and } \\
\text { compassion fatigue } \\
(\mathrm{r}=.21, \mathrm{p}<.001) \text {. } \\
\text { Moral distress and } \\
\text { compassion fatigue } \\
\text { were positively } \\
\text { correlated with } \\
\text { perceived reasons } \\
\text { medication errors } \\
\text { were not reported. }\end{array}$ \\
\hline $\begin{array}{l}\text { Osborne, J., } \\
\text { Blais, K., \& } \\
\text { Hayes, J. S. } \\
\text { (1999) } \\
\text { Nurses' } \\
\text { perceptions: when } \\
\text { is it a medication } \\
\text { error? }\end{array}$ & $\begin{array}{l}\text { Descriptive } \\
\text { comparative } \\
\text { study of } 57 \\
\text { Medical- } \\
\text { Surgical RNs in a } \\
700 \text { bed } \\
\text { community } \\
\text { hospital in South } \\
\text { Florida. }\end{array}$ & $\begin{array}{l}\text { Quantitative } \\
\text { (Survey) }\end{array}$ & $\begin{array}{l}\text { Modified } \\
\text { Gladstone } \\
\text { Questionnaire } \\
\text { Descriptive and } \\
\text { inferential } \\
\text { statistics used } \\
\text { for data analysis }\end{array}$ & $\begin{array}{l}\text { Key Findings: } \\
\text { *Nurses redefine } \\
\text { medication errors } \\
\text { based on critical } \\
\text { thinking skills } \\
\text { * RNs believed that } \\
\text { other RNs did not } \\
\text { report medication } \\
\text { errors out of fear } \\
\text { from co-workers } \\
\text { and manager, but } \\
\text { did not fear } \\
\text { reporting } \\
\text { themselves. } \\
\text { Recommend } \\
\text { changing } \\
\text { "medication error" } \\
\text { to "variance in } \\
\text { medication }\end{array}$ \\
\hline
\end{tabular}




\begin{tabular}{|c|c|c|c|c|}
\hline Author/Title & $\begin{array}{c}\text { Setting/ } \\
\text { Participants }\end{array}$ & Methodology & $\begin{array}{l}\text { Instruments/ } \\
\text { Psychometrics }\end{array}$ & Findings \\
\hline & & & & administration" \\
\hline $\begin{array}{l}\text { Mayo, A. M., \& } \\
\text { Duncan, D. } \\
\text { (2004) } \\
\text { Nurse perceptions } \\
\text { of medication } \\
\text { errors: what we } \\
\text { need to know for } \\
\text { patient safety. }\end{array}$ & $\begin{array}{l}\text { United Nurses } \\
\text { Association of } \\
\text { California. Union } \\
\text { of Health Care } \\
\text { Professionals RNs } \\
\text { in } 16 \text { Southern } \\
\text { California } \\
\text { Hospitals } \\
\text { Random Sample } \\
\text { 5000 RNS with } \\
\text { responses from } \\
983 \text { RNs }\end{array}$ & $\begin{array}{l}\text { Quantitative } \\
\text { (Survey) } \\
\text { *Replicated } \\
\text { Osborne et al. } \\
\text { study with larger } \\
\text { sample. }\end{array}$ & $\begin{array}{l}\text { Modified } \\
\text { Gladstone } \\
\text { Questionnaire }\end{array}$ & $\begin{array}{l}\text { Gap identified } \\
\text { between nurses' } \\
\text { perceived } \\
\text { knowledge and } \\
\text { actual knowledge } \\
\text { of what constitutes } \\
\text { a medication error. } \\
\text { No specific } \\
\text { demographic data } \\
\text { was associated } \\
\text { with nurse } \\
\text { perception / } \\
\text { reporting of } \\
\text { medication errors. }\end{array}$ \\
\hline $\begin{array}{l}\text { Hewitt, P. (2010) } \\
\text { Clinical Practice } \\
\text { Nurses' } \\
\text { Perceptions of the } \\
\text { Causes of } \\
\text { Medication } \\
\text { Errors: An } \\
\text { Integrative } \\
\text { Literature Review }\end{array}$ & $\begin{array}{l}\text { Literature Review } \\
9 \text { studies } \\
\text { throughout USA, } \\
\text { Japan, United } \\
\text { Kingdom and } \\
\text { Taiwan. }\end{array}$ & $\begin{array}{l}\text { Review of } \\
\text { Literature }\end{array}$ & $\begin{array}{l}\text { Review of } 9 \\
\text { studies varying } \\
\text { in methods - } \\
\text { quantitative and } \\
\text { qualitative. }\end{array}$ & $\begin{array}{l}\text { Key points: } \\
\text { * Understanding } \\
\text { the root causes of } \\
\text { why medication } \\
\text { errors occur will } \\
\text { help reduce errors } \\
\text { * punitive } \\
\text { measures to } \\
\text { combat medication } \\
\text { errors will only } \\
\text { cause more errors } \\
\text { to go unreported } \\
\text { * Administration of } \\
\text { medication is a } \\
\text { complex, } \\
\text { multidisciplinary } \\
\text { process that } \\
\text { requires scrutiny } \\
\text { from all directions } \\
\text { to ensure the safest } \\
\text { system possible. }\end{array}$ \\
\hline
\end{tabular}




\section{Research Study Participants Wanted}

- Are you an RN working at the bedside?

- Are you a Full-Time, Part-Time or Per-Diem Nurse?

\section{We want to hear from you!!}

I am a PhD student at the University of San Diego Hahn School of Nursing and Health Science conducting a study to investigate the relationships between organizational commitment (how committed you are to your organization), organizational-based selfesteem (how you feel about your organization), work engagement (how engaged you are at work) and nurses' perception of medication errors.

\section{What you need to know:}

- Information is collected by paper survey.

- The survey should take 15-25 minutes to complete*.

- The survey is anonymous. You will not be asked for your name or facility name.

*All participants will receive a "Peace, Love, Nursing" tote bag and aluminum water bottle for their time

\section{Questions? Want more information?}

Contact:

Vanessa Wertheim, MBA, RN

vwertheim@sandiego.edu or 858-337-5255

Linda Urden, DNSc., RN, CNS, NE-BC, FAAN

urden@sandiego.edu or 858-260-7609 


\section{APPENDIX F \\ IRB Approval}

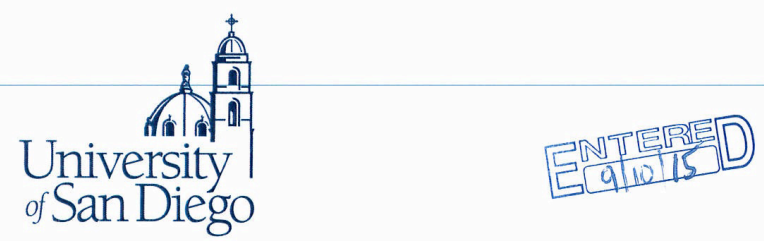

\section{Institutional Review Board \\ Project Action Summary}

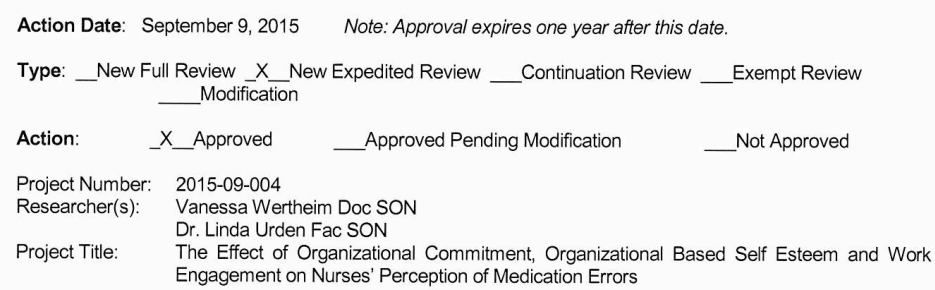

Note: We send IRB correspondence regarding student research to the faculty advisor, who bears the ultimate responsibility for the conduct of the research. We request that the faculty advisor share this correspondence with the student researcher.

Modifications Required or Reasons for Non-Approval

None

The next deadline for submitting project proposals to the Provost's Office for full review is N/A. You may submit a project proposal for expedited review at any time.

Dr. Thomas R. Herrinton

Administrator, Institutional Review Board

University of San Diego

herrinton@sandiego.ed

5998 Alcalá Park

San Diego, California 92110-2492

Office of the Executive Vice President and Provost

Hughes Administration Center, Room 214

5998 Alcalá Park, San Diego, CA 92110-2492

Phone (619) 260-4553 • Fax (619) 260-2210 • www.sandiego.edu 